Portland State University

PDXScholar

$1-1-2010$

\title{
Transformative Teacher Evaluation: Self Evaluation for High Performing Teachers
}

Carla Ann Sosanya-Tellez

Portland State University

Follow this and additional works at: https://pdxscholar.library.pdx.edu/open_access_etds Let us know how access to this document benefits you.

Recommended Citation

Sosanya-Tellez, Carla Ann, "Transformative Teacher Evaluation: Self Evaluation for High Performing Teachers" (2010). Dissertations and Theses. Paper 389.

https://doi.org/10.15760/etd.389

This Dissertation is brought to you for free and open access. It has been accepted for inclusion in Dissertations and Theses by an authorized administrator of PDXScholar. Please contact us if we can make this document more accessible: pdxscholar@pdx.edu. 
Transformative Teacher Evaluation:

Self Evaluation for High

Performing Teachers

by

Carla Ann Sosanya-Tellez

A dissertation submitted in partial fulfillment of the requirements for the degree of

Doctor of Education

in

Educational Leadership:

Administration

Dissertation Committee:

Tom Chenoweth, Chair

Ramin Farahmandpur

Kenneth Peterson

Gayle Thieman

Martha Balshem

Portland State University

(C)2010 


\begin{abstract}
Public schools are in crisis, as educators and legislators seek to provide high quality education to diverse students in a measurement-driven environment. The public educator's moral imperative is to assure that all children are literate when they leave school so they can thrive in our democracy (Dewey, 1944; Freire, 1998a; Giroux \& Giroux, 2004). Yet, the achievement gap persists, as poor African-American and Latino students under-perform as compared to white middle-class students (Ladson-Billings \& Tate, 1995). Additionally, public school teachers are predominately middle-class and White, while they teach increasingly diverse children of poverty.

In legislation, student assessment, teacher licensure, and research-based curricula have taken center stage. Teacher evaluation is noticeably absent (Danielson, 2002; Iwanicki, 1990; No Child Left Behind Act, 2002). Teacher evaluation is static and mired in politics; it has not historically helped improve school (Peterson, 2000). Investigating teacher evaluation's potential as an overlooked tool to improve teaching for all teachers and students in public school is urgent in this climate. As Stronge and Tucker (2003) asserted, "Without capable, highly qualified teachers in America’s classrooms, no educational reform process can possibly succeed” (p. 3).

This problem-based learning dissertation addresses a real problem in practice: how to make teacher evaluation meaningful for high-performing teachers. This study explores Wood's (1998) call for a move from traditional to transformative evaluation.
\end{abstract}


Ten high performing teachers field-tested a self-evaluation handbook. They explored study options designed to help them critically reflect on their own teaching, connect with students, reflect, and set new goals. This work shows promise to help teachers and students engage in a more democratic, caring and loving public place we call school.

This work is timely. After all, "When all is said and done, what matters most for students' learning are the commitments and capacities of their teachers” (DarlingHammond, 1997, p. 293). 


\section{DEDICATION}

I dedicate this work to all students. Keep longing for a beautiful education.

Challenge your thinking. Make discoveries. Revel in love. May you thrive with the help

of amazing educators. And may we, your educators, continue to love public education, grow ourselves, and embrace the power of passion. 


\section{ACKNOWLEGMENTS}

I celebrate the amazing, outer urban middle school teachers who participated in this study. Thank you one and all for your passion and commitment. Without your willingness to be open, to examine your own work, and to see the light in the eyes of every student, this project would have never moved forward. May you continue to have the bravery to be like a fish out of water.

I lovingly dedicate this dissertation to my sons Bamidele Babatunde Sosanya, Oluwaseyi Ayomini Christopher Sosanya, and Temitope Oladimeji Sosanya. I acknowledge our struggle and accomplishments. Keep on the grind. Don’t look back when the going gets hard. You have become wonderful men!

I could not have completed this work without the loving support and belief of my husband, Inocencio Tellez-Ruiz, who is a gentle, hard working and intensely intelligent man. He spent many hours alone while I studied and fussed.

Many thanks to my mother, Betty Jane Trembley and my stepfather, Stewart Sheerman, who have learned how to love each other unconditionally. This is quite an accomplishment and a testament to the ability for all of us to continue growing. I know it was hard to delay our plans, and to understand me when I was deep in study.

To my father now on the other side, David Leo Trembley - Dad, I made it! 
The miraculous completion of this work is a result of mentors and advocates all around me. To my Advisor, Tom Chenoweth - thanks for opening doors for me and spending countless hours reading my work. To my Committee: Ramin Farahmandpur, Ken Peterson, Gayle Thieman and Martha Balshem - you have supported me to grow beyond my wildest dreams. Thanks for your scholarship. Keep dedicating yourselves to education for all. 
TABLE OF CONTENTS

Page

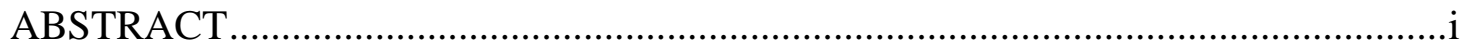

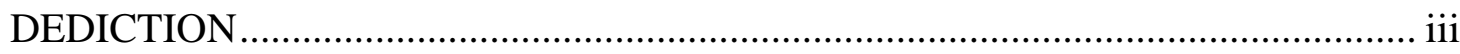

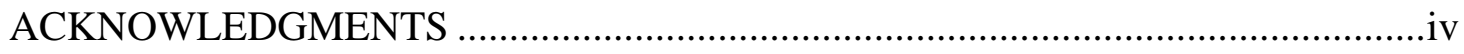

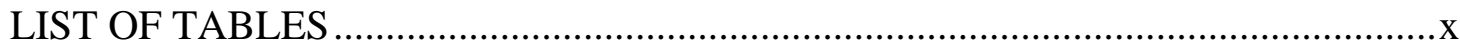

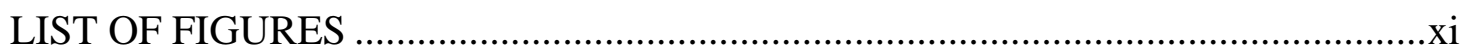

\section{CHAPTER}

I PROBLEM STATEMENT AND SIGNIFICANCE ........................................

Study Setting: A School Scenario.....................................................1

Statement of the Problem...................................................................

Context: Demographics and Complex School Change..........................12

Purpose: Democratic Education and School Improvement ....................15

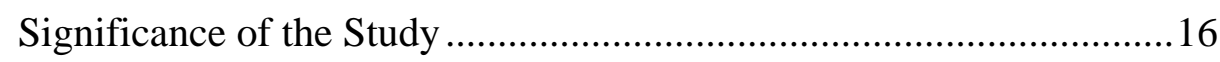

Definition of Terms.............................................................................. 18

Chapter Summary ………………………………………………....20

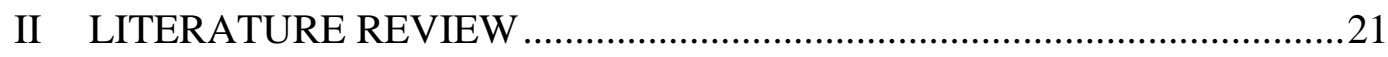

Current Reality and Unfulfilled Potential ..............................................21

An Historical Overview ………………...............................................22 
Teacher Evaluation and School Reform .........................................29

Structural Frameworks and Teacher Evaluation Goals .......................34

Ethical Considerations ....................................................................37

Teacher Evaluation in a Political Context ..........................................44

Critical, Democratic Education, and Evaluation................................48

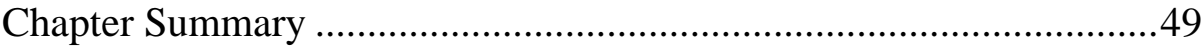

III RESEARCH DESIGN AND METHODOLOGY …...................................51

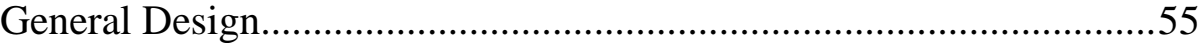

Research and Development Cycle: The PBL Self Evaluation Handbook................................................................................56

Preliminary Field Test.......................................................................57

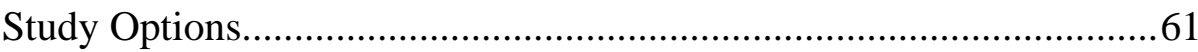

Transformative Options

Traditional Options

Culminating Research Session.......................................................66

Main Product Revision: Steps and Description of Revisions Made.....67

Data Collection Procedures................................................................68

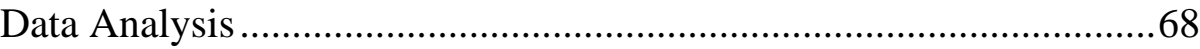

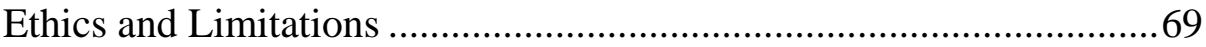

Description of PBL: Possible Outcomes and Next Steps ....................72

Description of PBL: Self Evaluation Handbook.................................73

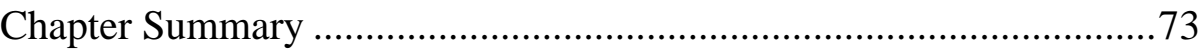

IV THE PROBLEM BASED LEARNING PILOT STUDY …..........................75 
Pilot Handbook Study Overview and Process .........................................75

Pilot Study High Performing Teacher Participants.................................78

Study Sessions

Highlights of Individual Sessions

September Session: Orientation, Study Model Selection, Entry Survey

Overall Observations from Entry Survey

October Session: White Privilege and African

American Guest Speaker

November Session: Resilience, Race, and Class

December Session: Ruby Payne, Personal Qualities, and

Positive Attributes

January Session: Leadership and Resilience

February Session: Culmination Sessions

Teacher Reports from Study Models

107

Educational History

Iceberg Model

SIOP Lesson Planning

Surveys

Mind's Eye Model

The Spiral Model of Continuous Improvement

Community Visits

Democratic Attributes

Overall Trends from Study Model Presentations

Trends from Exit Self Surveys......................................................117

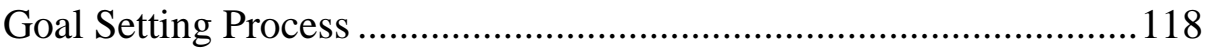

Unanticipated Challenges Faced During the Study .............................119

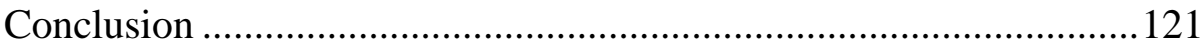

V OUTCOMES AND IMPLICATIONS ……………………......................123

Creation of the Handbook and Changes During the Study..................125 
Benefit of Problem Based Learning......................................................126

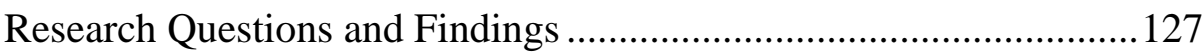

Efficacy of Study Options

Models, Intent, and Outcomes ......................................................134

Iceberg Model

Mind's Eye Model

Surveys

SIOP

Democratic Attributes

Spiral Model of Continuous Improvement

Home Visits

Educational History

Overall Observations of Teachers toward Study Methods

The Role of Professional Learning Communities

Merit Based Pay, Portfolios, Rubrics, Classroom Walk

Abouts, and so Forth

What is a High Performing Teacher?

The Role of Love in Teaching and Learning in this Study

Limitations and Roadblocks

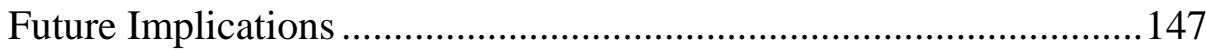

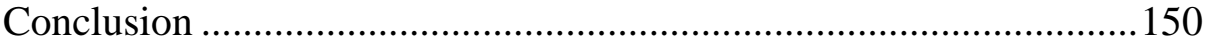

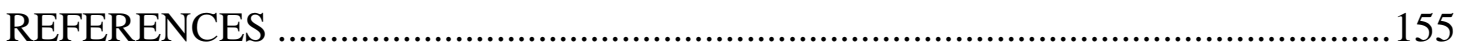

\section{APPENDIX}

A SELF EVALUATION HANDBOOK FOR HIGH PERFORMING

TEACHERS ....................................................................................... 164

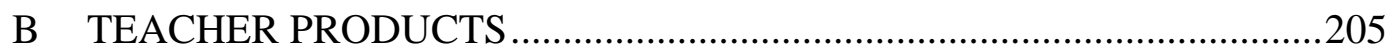




\section{LIST OF TABLES}

Table

Page

1. Historical Development of Teacher Evaluation ......................................23

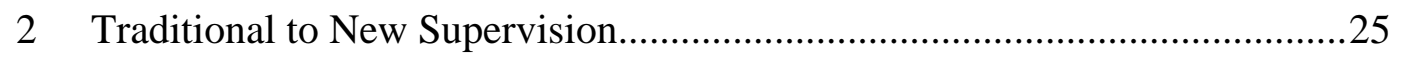

3 Differences between Traditional and Transformative Supervision................27

4 Views from Established to Emerging Practice ........................................28

5 Shifting toward Cultural Competence ................................................... 42

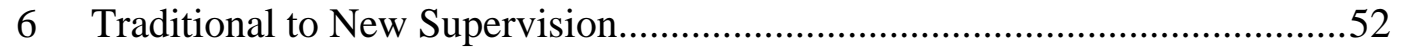

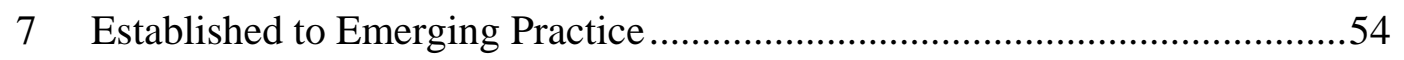

8 Field Test Timeline for the Teacher Self-Evaluation Handbook ..................60

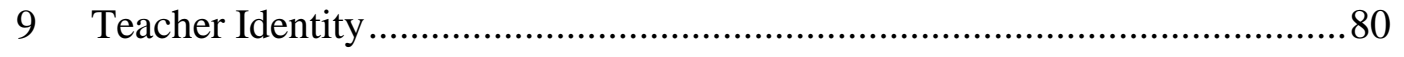

10 Pilot Study Lesson Topics and Session Experiences ................................81

11 Word Analysis of Initial Teacher Evaluation Response...............................88

12 Teacher-Student Connection and Disconnection .....................................92

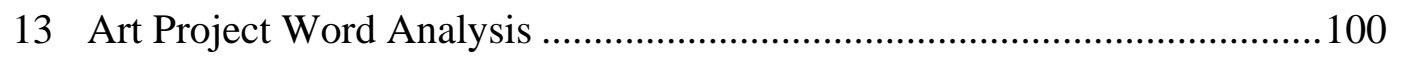

14 Teacher Responses to Research Questions...........................................128

15 Study Models and Teacher Comments.................................................130 


\section{LIST OF FIGURES}

Figure $\quad$ Page

1 Organizing Teacher Evaluation, Staff Development, and School

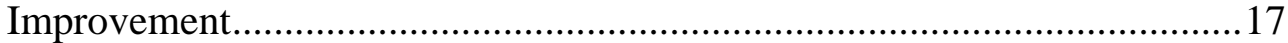

2 Spiral Model of Continuous Improvement .............................................33

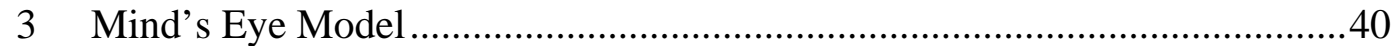

4 Iceberg Model of Teacher Reflection .......................................................43

5 Student and Teacher at the Center ....................................................... 47 


\section{CHAPTER I}

\section{PROBLEM STATEMENT AND SIGNIFICANCE}

\section{Study Setting: A School Scenario}

A grandparent comes to a suburban middle school to register his grandson, Elijah, "You are rude. I want to speak to the principal,” he tells the secretary. The principal emerges from her office curious about the noise she hears. She listens intently. Both Grandpa and Elijah worry if the new school and neighborhood are safe for Elijah and if he will face racism. Having left the inner city where they had cultural comfort, they are in an unfamiliar place. Elijah’s inner-city neighborhood gentrified so quickly they could no longer afford to live there. They, and other minority and low-income families, migrate to affordable apartments further from the central city. The principal takes them on a school tour and tries to reassure them.

Joaquin comes to register at the same school. In Michoacan, Mexico, Joaquin learned using workbooks that reinforce televised lessons in a remote school. Speaking Purhepecha as a child, he is learning Spanish as a second language. Although he lived in poverty, he experienced an intact culture in Michoacan. His mother brings a bilingual (Spanish and English) cousin to interpret for them. The family is nervous in the strange surroundings. The translator greets Joaquin in Spanish. Joaquin’s mother waits while others complete registration forms, not understanding Spanish or English. 
Also from Michoacan, Veronica comes with her custodial sister to register at this school. At private school in Mexico, she completed classes almost identically aligned with curricula in the U.S., is fluent in Spanish, and studied English. Teachers viewed her as capable. Veronica earned high scores of tens or nines, never lower than an eight on her schoolwork. When a teacher asks questions in Spanish, Veronica smiles and replies in Spanish, helping complete registration forms. She hopes to improve her English quickly and wants to do well in this new school and culture.

Another mother and her son, John, come in to register. They are White, upper middle class, and are comfortable in the office. The mother quickly completes all forms and asks when band practice will begin. She is also ready to volunteer in school and worries whether her son will achieve his potential, especially in advanced math class.

In all, 100 new students register at the beginning of each school year. This nearly matches the 85 no-show students. Harried secretaries respond to record requests. On the first day of school, 800 students mingle during their few minutes before school starts. Students speak several languages, peer over their schedules, and compare summer stories.

Most new students come to this school out of economic necessity, and many are members of minority groups. Elijah moved to a suburb as the inner city became too expensive, while Veronica and Joaquin came to the United States seeking a better life. Some new students grieve cultures left behind. Many live in hastily built apartments, doubling up with friends or family. They have few friends and do not know school rules. Many struggle academically because of language barriers or low skills. 
At Lincoln Middle School, and schools like it, change and challenge are realities. Over 30\% of students are English Language Learners (ELLs). Most ELL students come from Michoacan State, Mexico. The poverty rate surpasses 70\%. Minority students make up 61\% of the total enrollment. Most teachers speak English only, are White, and earn middle class wages. Most began teaching 10 or more years ago when over $90 \%$ of students were from White middle class families. Even so, most teachers love school, have passion for their subjects, and want to help students thrive but experience extreme change. Sometimes the community is afraid to trust across differences

Mrs. Johnson begins her science class. She has a pacing guide she must follow to cover the curriculum. Joaquin and his new friend Veronica are 2 of 10 ELL students in the mainstream science class. John and Elijah are also in this same section. Mrs. Johnson worries about whether all students understand but has 45 minutes for this lesson, and the science test is around the corner. Are Joaquin and Veronica learning? Can Elijah read the text? Will John participate? She is not sure.

Later in the year, the local paper publishes Lincoln Middle School's annual report card. Teachers feel attacked. The attendance rate is falling. When teachers review discipline, achievement and attendance statistics disaggregated for all subgroups at a staff meeting, the room is silent. White students met benchmarks in math and reading, while Special Education, Black, Hispanic, and ELL students do not. Black students are statistically more likely to receive negative discipline reports than all other groups. Teachers do not understand how poverty, class and race affect their students. 
Teachers and the principal begin to work together to improve the school. Open and uncomfortable conversations about student performance do not go away. Some teachers eagerly work on teams to improve teaching and learning; others worry, think they can outlast the reform efforts, or seek transfers. Can all children achieve? Can teachers improve their everyday practice? Perhaps...

A Hall Monitor brings Veronica to the office from Mrs. Johnson’s class. Veronica is visibly agitated, her arms crossed, the blood absent from her knuckles - White. She vigorously rocks in the rocking chair. Later, she calms herself. Finally, it is time to talk. “What is wrong?” the bilingual assistant principal asks. "This is your first time to swear at a teacher. I am disappointed. This is not like you.” Veronica reveals she has not eaten since yesterday's lunch. Additionally, her cousin was shot and killed in Los Angeles last night. She says, “Why should I try anyway? I won’t live to grow up. Besides, my teacher doesn't care about me. She told me to copy from my neighbor. That's cheating.” During the teacher's preparation time, the assistant principal helps Veronica talk with her teacher. Mrs. Johnson says, “Oh, I didn’t know. Why didn’t you tell me? ” They hug, agree to start over, and plan how Veronica can let Mrs. Johnson know how she feels.

This teacher, like many others, loves her work and cares about students. Indefatigable, good teachers want children to thrive. Can teachers working with students, parents, principals, and the community realize a wonderful education for all? What do we believe is possible in public education?

At the least, critical, passionate, morally compelled educators improve school for all. If we love public education as we love democracy, then high quality education for our 
students is essential. Each student in our school must leave school prepared to be analytical, literate, and altruistic. Teacher by teacher, student by student, the time has come to explore every possible way to improve school for all.

I am an incurably love struck educator, the White, middle-class female principal of the brief vignette. I love and am a product of public education. The complexity of public school is mind-boggling. Helping all students learn to their highest potential is a fabulous quest. What can the future can hold for each student?

I became addicted to learning as a small child, and even now I wriggle with excitement when I learn something - anything - new. Public school teachers opened my world and piqued my curiosity. They taught me to love to learn - to know I was special. Mrs. Massey, my third grade teacher; Mr. Caulkins, my fifth grade teacher, and Dr. Chenoweth, my Doctoral Advisor, connected with me, cared, and opened the world to my exploration.

My wonderment with school continues. I anticipate the first day of school and lose sleep the night before. Lesson plans, shiny floors, cafeterias, playgrounds, desks, a red apple, the crack of a new book, parents, other teachers, students, notebooks, new pencils, crayon smell, Individual Education Plans, the Gestalt “aha” of learning led me on. My love affair with school has no equal.

An early evaluation experience while I was a teacher was my first disillusioning experience in school. It was a fiasco. Called in to the Principal's office, he handed me a form with several boxes checked. The Principal never observed me teaching. We had never talked about my students and their learning. We had no time, or trust. I felt de- 
motivated and powerless. A novice teacher, this end-of-year statement left me crestfallen. I left public education for many years: years later I intentionally re-entered to try to improve school for all.

I am on a continuous quest to improve public education. Educators are morally compelled to help all students thrive. All students must master the three "Rs" - reading, writing and 'rithmatic. Each student in our school must leave us prepared to be analytical, literate, and altruistic. Unfortunately, achievement gaps persist, and students face vastly different futures.

Entering the principal ranks, I believed I could help teachers improve. I thought we would honestly reflect on teaching and learning. The reality of working in public education is harsh. We keep grueling hours. Time for loving interactions is scarce. I hurriedly listen to teacher goal setting sessions in the fall, hope to get in about three observations for the third of teachers I directly evaluate, trust other administrators to evaluate the other two thirds, and then sprint to write up summative evaluations primarily single-handedly. Certainly, I want to do collaborative evaluations, but time, politics, challenges presented by children and families, demands by central office and resources realistically do not permit a deeply caring and meaningful exchange.

Notwithstanding, I remain passionately motivated to improve teacher evaluation. Can teacher evaluation help each teacher grow, form close relationships with children, and improve student results? Can we help teachers to understand their own identities, learn to love their students and connect with them in meaningful ways? If we love public 
education as we love democracy, then raising the quality of education for our students and aligning all we do, including how we engage in teacher evaluation, is essential.

This study is my attempt to revisit teacher evaluation as a tool to realize a beautiful public education for all students.

\section{Statement of the Problem}

Our first responsibility in public education is to educate all students and help them become active participants in a democratic society. Students have the right to be instructed with effective and fair methods by professionals. It is the teacher's responsibility to do so (Peterson, Kelly, \& Caskey, 2002). By fulfilling this, our moral imperative, we sustain democratic values and principles. As Giroux and Giroux (2004) aptly phrased it:

An educated and active citizenry is indispensable for a free and inclusive democratic society; democratic politics requires the full participation of an informed populace. A substantive democracy simply cannot exist without educated citizenry. (p. 4)

Since public schools enroll all students, they are our best hope to educate the entire populace. Public schools must equip all students to engage in our democratic community, negotiate fast-paced change in the world, and safeguard democracy (Apple \& Beane, 1995). The first step on the ideal student's journey to becoming a literate member of the populace is to learn with a teacher in a loving, rigorous, respectful, inclusive classroom. Such a classroom assures security, freedom from criticism and student engagement (Daggett, 2008). School essentially happens in the student-teacher interaction. Everything in the school system should maximize that interaction. After all, “When all is said and done, what matters most for students' learning are the 
commitments and capacities of their teachers” (Darling-Hammond, 1997, p. 293). In this $21^{\text {st }}$ century milieu, I believe that teacher evaluation may hold untapped promise for teacher and whole school improvement. To that end, we must examine all practices within education and their potential to create a high quality public school environment in which students and staff can thrive.

What happens in classrooms is first and foremost about the personal and collective connections that exist among the individuals who inhabit those spaces (Nieto, 1999). Without strong relationships between teachers and students, achievement gaps widen (Freire, 1998a). Mystified teachers demand compliance while diverse students feel disengaged and powerless. Continuing their practices unchanged, teachers reinforce and reproduce institutional racism (Bateson, 1994; Nieto, 2003). They unwittingly fail to affirm unique student realities (culture, class, race, family constellation, spirituality, experience base) other than their own (Nieto, 2002). If teachers can understand their own and their student identities, perhaps they can connect more closely with their students.

In fact, teacher and student connection is essential. In a study conducted by Kauchak, Peterson, and Driscoll (1985), teachers reported that student reaction is one of their most-used sources of feedback about their instructional effectiveness. Teachers seek good feelings between themselves and their students (Lunenburg \& Ornstein, 2004). Positive reactions reinforce teachers, and student connections grow. If teachers perceive negative student reactions, they may blame students for their perceived failure.

Public schools are facing a financial crisis due to economic reductions exacerbating the rate of required change. Together, teachers and students are in the throes 
of a cultural shift; how they respond is key to student engagement and achievement. Issues of equity, race, cultural sensitivity, poverty, technology, and meeting diverse needs become urgent areas of growth for teachers. Even after cultural awareness or poverty training, frustrated teachers can be contentious - rejecting change. Yet, they mourn close relationships with students and families. As educators and legislators seek to provide high quality education to increasingly diverse students in a climate of standardized testing and accountability, resources are dwindling. In school improvement policy, student assessment, teacher licensure, and research-based curricula have taken center stage.

Although teachers and principals regularly engage in teacher evaluation, it is visibly absent from school improvement efforts. There are many reasons for this. First, teacher evaluation is a predictable, ritualized, but generally ineffective interaction (Acheson \& Gall, 2003). Second, there are those who believe that teacher evaluation is too difficult to change (Peterson, 2000). Finally, others purport that teacher evaluation is a non-event (Palmer, 1997). Teachers are isolated and powerless in their evaluation experiences. Even if they disagree with the summative evaluation, teachers can only refuse to sign or submit their own statement (Glickman \& Kanawati, 1998).

When effective, teacher evaluation recognizes student achievement, acknowledges good practice, supports teacher goals, shapes performance, motivates to improve on weaknesses, and removes the rare bad teacher from the profession (Peterson \& Peterson, 2006). Additionally, evaluations generally do not determine professional development or connect to whole school improvement (Iwanicki, 1998). When teacher evaluation uses rubrics (Danielson, 2002), a transformative approach (Wood, 1998), or a 
reflective clinical evaluation process (Pajak, 2000), it can offer specific feedback to teachers. However, the teacher remains the receiver of information in most experiences.

The literature on teacher evaluation confirms that teacher evaluation is fraught with challenges and is least effective or meaningless for long-term, proficient, or high performing teachers (Peterson, 2000). These teachers are ethically driven and motivated to teach well. They work passionately to transform their classroom teaching practices for all students (Danielewicz, 2001). They are morally determined to raise the bar and close the achievement gap (Fullan, 2005). These loving teachers practice in isolation and have little time to reflect on their teaching.

High performing teachers are professional; many are teacher leaders. Kauchak et al. (1985) asserted that "professionals exert control over the way that their performance is evaluated; workers do not” (p. 37). Peterson and Peterson (2006) proposed that teachers can improve their own evaluations and select the most pertinent data sources for themselves. Teachers behave more responsibly when they share the authority involved in personnel evaluation. In other words, when teachers are central to their own evaluation, they can commit to their own growth and pinpoint effective change.

Defining high performing teachers can be difficult, as there are many interpretations of what a high performing teacher is. Lunenburg and Ornstein (2004) offered another description of the teacher-leader or star teacher:

Star Teachers...have internalized their own view of teaching, their organization of subject matter, and their own practices through experience and self-discovery.... Star teachers reflect on what they do in the classroom, why they do it and the best way to do it. They are also guided by the expectations that inner city and poor children can learn, think, and reflect. (p. 540) 
By this definition, star teachers work well in challenging schools and enjoy seeing their students learn. Students, families, other teachers, and the community respect them. Such teachers continually improve instruction. These traits are essential in hard-hitting schools, if the connection between the student and teacher are vital to the student's success.

Principals are frustrated with teacher evaluation. Even when committed to evaluate teachers, principals must prioritize their time; they focus on struggling teachers and may minimally interact with high performing teachers. In fact, $26 \%$ of respondents in a U.S. Government survey reported that their building principal or supervisor never evaluated them in the previous year (Lunenburg \& Ornstein, 2004, p. 559). Even when commendatory, evaluation can seem redundant and disconnected.

This study explored teacher evaluation as an underutilized tool to improve school, with empowered, high performing teachers central to the process. Teacher participants hold contract status. They have received positive evaluations in the past. They qualify for multiple-year goal setting, but often only participate in traditional clinical evaluation. These teachers commit to school wide improvement efforts, and often participate in committees to improve school.

This study explored teacher evaluation as a tool for high performing teachers to grow and improve school (Iwanicki, 1998; Lunenburg \& Ornstein, 2004; Peterson \& Chenoweth, 1992). It applied theory to practice, and explored moving from a traditional clinical evaluation model to a more transformative model (Pajak, 2000; Wood, 1998). Teacher leaders collaborated with the researcher over a period of two years prior to the study, learning about the Iceberg Model and Spiral Model in professional development 
sessions. These models were included in a self-evaluation handbook, developed with teacher input. In this study, teacher leaders field-tested the handbook. This study is a problem-based learning model. Study options in the handbook placed high performing teachers central to their evaluation. This problem-based-learning model encouraged teachers to communicate, think critically, and reflect on their teaching.

All 10 teacher participants completed the study. Participating, high performing teachers explored “mental models...deeply ingrained assumptions, generalizations, or even pictures or images that influence how we understand the world and how we take actions” (Senge, 2000, p. 18) by using transformative study options. Participating teachers found all transformative study models meaningful, and worked to improve their connections with students, and their teaching. They reported that the dialogue with others and using a model over time helped them improve their practice. They shared their learning in a culmination session, developed goals for the future, completed journals and studied together. Two teachers chose to be individually interviewed. Four of 10 teachers completed Goal Setting Forms. Teachers reviewed all transcripts and products throughout the study. Participating teachers shaped the handbook, lessons, and the process.

\section{Context: Demographics and Complex School Change}

Lincoln Middle School and others like it are in crisis. As inner cities gentrify and outlying areas gain affordable housing, diverse families move to schools in the suburbs. Schools, which formerly enrolled $98 \%$ of students who were White and middle class, experience drastic increases of minority and impoverished students. In the urban metropolitan area where this study was conducted, over the last five years, 1,100 African 
American students left inner city schools, and enrolled in the inner ring of suburban districts. Additionally, Hispanic enrollment grew by 3,000 over the same period (Melton, 2006). Reflecting this trend, Lincoln Middle School became a minority majority, highpoverty school; teachers are middle-class and White.

The enrollment at Lincoln Middle School has remained slightly above or below 800 students, but mobility is hidden in the overall number. Each year from 2004 to 2008, 230 to 270 students move in and a like number move out. Free and reduced lunch statistics from 2005 to 2008 have increased from $69 \%$ to $76 \%$. At the same time, White enrollment has decreased from 45\% to 38\%; Hispanic enrollment has increased from $29 \%$ to $34 \%$; Asian enrollment has increased from $11 \%$ to $15 \%$, and African American enrollment has decreased from $14 \%$ to $12 \%$ (least significant in number and percent). These trends align to the nation-wide research of Fry (2009) who reported that the increase in America's suburban public schools has been due to the enrollment of new Latino, African American and Asian students. In 2008, Lincoln students were 22\% ELLs and 14\% Special Education.

During the same period, in Lincoln's report cards, Asian students performed at the highest level on State testing, followed by White, African American and Hispanic consistently in all testing areas. Student surveyed believed that teachers do not understand their individual realities. Student discipline statistics showed that African American boys were most likely to receive negative discipline referrals, followed by Hispanic males. White girls were least likely to receive referrals. These trends aligns to the work of Gregory and Weinstein (2008) who reported that African Americans are 
over-represented in suspensions and defiance, and that students are less likely to connect with teachers who do not care about them and who do not have high expectations. Lincoln teachers in this and many other schools like it are upper middle class and White. Together, teachers and students are in the throes of a cultural shift; how they respond is key to student engagement and achievement.

Issues of equity, race, culture, poverty, technology, and class are urgent areas for teacher growth. Teachers and students do not know how to connect with each other across difference in classrooms. Sleeter (2001) lamented this all-too-common phenomenon, "Education in many communities of color, as well as many poor White communities, is in a state of crisis. Students are learning far too little, becoming disengaged, and dropping out at high rates” (p. 94). Teachers should explicitly examine their own as well as student identities so that reciprocity grows. Reciprocity is fertile ground for strong relationships.

Increasing diversity is not the only challenge. Orfield (2001) reported the re-segregation of schools; statistics show that over $70 \%$ of Black students attend predominantly minority schools. Latino student enrollment is increasing - from $20 \%$ in 1968, to more than 33\% in 1998 - in intensely segregated schools.

When teachers began their careers in our formerly suburban school, long-term White teachers anticipated teaching and retiring with children who looked, thought and acted like them. Teacher beliefs, life styles, and behavior are now in conflict with those of their students (Bogdan \& Biklen, 2003). Some teachers feel unsafe in the halls or mourn former years when "parents cared and came to school events." Teachers make 
comments such as, “Ramon knows what I am saying but pretends he doesn’t know,” or “Black students don’t respect anyone and are so loud,” or ”I don’t know anything about poverty.” Teachers feel inadequate or baffled; some perceive students as less capable and lower their expectations. They ask, "You don’t expect me to be able to teach these students, do you?” Some inconsolably grieve as the familiar becomes strange.

\section{Purpose: Democratic Education and School Improvement}

Public educators have a moral imperative to provide democratic education for all. Democratic school is just and inclusive; it helps all students achieve their potential. Democracy assures that our society seeks the welfare, dignity, and rights of all. According to Danielson (2002), "Schools have a particular responsibility to break the cycle of poverty and ignorance, because it is through education that young people can escape from their apparent destinies” (p. xii). Schools are our best hope to assure a democratic future because schools are microcosms of our society. If we create inclusive, caring, rigorous learning environments with student literacy, rights, and responsibilities at the forefront, students will be prepared to contribute to our society.

In response to the 1994 Goals 2000 Act and the No Child Left Behind (NCLB, 2002), schools submit plans and report outcomes. "Heavy-handed schemes like No Child Left Behind (NCLB) in the United States and a prescriptive preoccupation with targets in England during the 1990s are bad for sustainability” (Fullan, 2005, p. 23). These efforts are narrow in their measurements, are unfunded, and do not account for complexity required by schools to create excellence. Student behavior, poverty, attendance, test participation, and outcomes by subgroup determine a school's rating. Testing outcomes 
feel impossible to reach - a game made worse when rules change midstream. Reports published in local papers increase anxiety. Schools can receive failing or unsafe ratings and lose funding. Educators fear failure and work urgently to find answers. It is essential in a quick-fix environment that we seek sustainable, high-quality change critical to our schools.

\section{Significance of the Study}

Teacher evaluation is typically absent in an answer-seeking school improvement climate. Clinical evaluation helps grow the novice teacher and can winnow out ineffective teachers, but does not generally help long-term, high-performing teachers improve. Due to its history, range of purposes, poor definition, and power structure, high performing teachers often find teacher evaluation meaningless (Peterson, 2000). Teacher evaluation merits an in-depth realignment to support high-performing teacher-leaders who work to improve teaching and learning.

High performing teacher leaders hold answers to the school improvement

dilemma. They commit to improve school for all. In traditional teacher evaluation, these same teachers are powerless. They cannot help evaluate their own teaching. Teacher evaluation must be more reflective, sustainable, and linked to whole school improvement (Iwanicki, 1998). Consider Figure 1, representing Iwanicki’s (1990) suggestion for integration. 
INTEGRATION TO IMPROVE SCHOOL

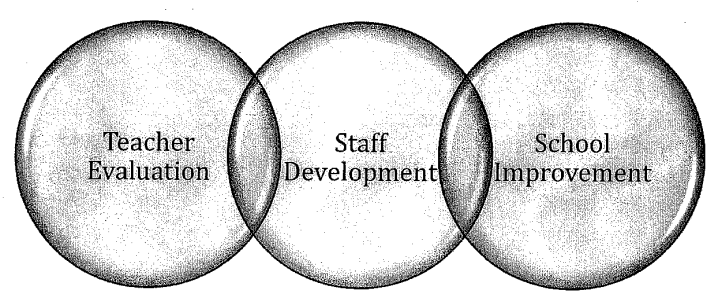

A Disjointed Approach

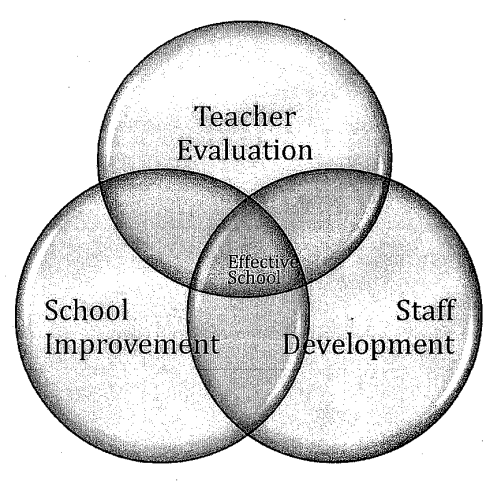

An Integrated Approach

IWANICKI (1990)

Figure 1. Organizing teacher evaluation, staff development, and school improvement.

In most evaluation, teachers and principals set goals for teacher growth. Principals set school growth goals. Teacher evaluation usually does not contribute to whole school reform and is not connected to staff development. Teacher evaluation seldom places teacher and learner interactions at the center of the process (Darling-Hammond 1997; Peterson, 2000). If it is to be continued, teacher evaluation must be a tool to transform school; it must provide opportunities for teachers to reflect, set attainable goals, and realize democracy within the classroom. 
If we truly commit to educating all students, we must reinvent our practice. Reinventing our practice does entail assessing all of our actions in schools. Teacher evaluation may be a key to realizing school improvement. We must sustain our efforts over time; the work is not easy. I believe that teacher evaluation holds promise as a strategic tool to improve school for all.

\section{Definition of Terms}

Clinical Supervision and Evaluation - from the seminal work of Robert Goldhammer in the late 1960s and Morris Cogan in the early 1970s, clinical supervision is the prevalent teacher evaluation model (Nolan \& Hoover, 2004). This standardized, articulated approach includes goal setting, a pre-observation conference, in-class observations, and a post-observation conference.

Cycle of Continuous Improvement - adopted from the work of Chenoweth and Everhart (2002) in which a person or group defines current reality, sets goals, plans, engages in a change effort then reviews reflects or evaluates and engages in change again - an iterative process. The spiral is often used rather than the circle; a spiral is a like a helix. It is recursive. A learner can reflect back and look ahead on the spiral while working to improve.

High Performing Teachers - contract status, and consistently receive positive evaluative reports. They often take leadership roles within the school or district. In this study, high performing teacher leaders are given the opportunity to self evaluate.

Iceberg Model - adopted from the Systems Thinking and Dynamic Modeling Project (2002). There are conscious and subconscious ways of making observations. Ten 
percent of an iceberg is easily visible, with $90 \%$ below the water. Similarly, $10 \%$ of what we know when we interact with others is visible; $90 \%$ is not. The $90 \%$ informs all of our actions, and includes structures, beliefs, and behaviors we experience in life. If unexamined, we may severely limit our knowledge or effectiveness in interactions.

Love in Education - It is impossible to teach without the courage to love (Freire, 1998a). Love is predicated on high standards, rigorous demands and respect for students, their identities and their families (Nieto, 1999) Love connects us at deep levels (hooks, 2000).

Mind's-Eye Model - based on work of Wink and Wink (2004), people's experiences and identities inform all decisions they make interacting with those around them.

Self Evaluation - a teacher establishes his or her current levels of performance and questions in one or more areas of teaching and then works to improve his or her teaching.

Star Teachers - teachers effective with students of poverty. They reflect on what they do in the classroom, why they do it and the best way to do it. They expect that inner city and poor children can learn, think, and reflect (Lunenburg \& Ornstein, 2004, p. 540).

Teacher-Leaders - teachers who serve on improvement teams and represent their school in building or district level improvement efforts (See high performing teacher).

Teaching-Learning - based on the work of Freire (1998a, p. 29), who believed that teaching and learning cannot be separated. 
Trust - the more trust within the group, the greater the results or change thee group can achieve. Trust is an aspect of love. Trust is increased by honesty, integrity, reliability and dependability. High trust environments have a low rate of crises, and are focused on outcomes (Stillwell, 2003).

\section{Chapter Summary}

We can no longer be satisfied with a minimally useful, labor intensive, meaningless interaction in any of our work in school, including teacher evaluation. Moreover, it is urgent that we realize the goal of a loving, democratic public education effective for all. Teacher evaluation must be re-examined along with other practices to improve public schooling for all students. Can teacher evaluation help us redefine our work and improve education?

This dissertation addresses a real problem in teaching practice. The pilot study employed a problem-based learning approach. Teachers self-assessed, using two transformative study options to guide their reflection, improvement and evaluation. Teachers worked individually, in pairs, and as a group. Questions and study models caused deep reflection and critical examination of issues. All 10 teacher participants completed this study. Ultimately, teachers shaped the process and the Self Evaluation Handbook. 


\section{CHAPTER II}

\section{LITERATURE REVIEW}

This literature review provides background to support a shift to transformative teacher evaluation conducted by teacher leaders as a part of their reflective work. The literature review includes these topics: (a) historical overview, (b) teacher evaluation and school reform, (c) structural frameworks and goals of teacher evaluation, (d) ethical considerations, (e) teacher evaluation within a political context, and (f) critical, democratic education and evaluation.

\section{Current Reality and Unfulfilled Potential}

That people have grown dissatisfied with traditional teacher evaluation there can be little doubt. When the reasons for this dissatisfaction are examined, however, it becomes clear that teacher evaluation means different things to different people. For politicians critical of public schools, and their allies, teacher evaluation symbolizes a "get tough" strategy to ensure that incompetent teachers are removed from classrooms. For teachers, and, to some extent, school administrators, teacher evaluation reform constitutes an opportunity to improve school climate, promote professionalism, and provide constructive feedback to teachers as they undertake ongoing professional development (Duke, 1995, p. 185).

While teacher evaluation can be used as a get tough strategy, that approach is antithetical to building a climate for professional growth. A negative environment does not engender an open dialogue. The teacher experiencing negativity is likely to withdraw from the supervisor. Nonetheless, teacher evaluation can be an improvement opportunity. Due to its history, range of purposes, poor definition, and power structure, teacher evaluation is 
often meaningless, especially for high performing teachers (Peterson, 2000). Teacher evaluation determines if a teacher works, gains highly qualified status or loses employment. The high stakes nature of these outcomes also does not lend for open exchange focused on the practices of the teacher and the resulting abilities of the students. Historically, teacher evaluation has not helped teachers improve their professionalism, and is seldom included in school improvement efforts (Iwanicki, 1998). Harris (1998) asserted that in the field of school supervision research, teacher evaluation may be the most conflict-prone.

\section{An Historical Overview}

American communities built schools as early as 1642 in America to teach youth the values of the community as well as reading, writing, and arithmetic. Interestingly, these essential purposes have not significantly changed in more than 350 years. Since their earliest years, outside or supervisory administrators have evaluated most schools. Supervision was used to assure the quality of schools to the communities who sent their children to be schooled. Supervision in public education still serves that purpose. Duffy (1998) organized the historical development of teacher evaluation into four broad periods. These four periods are: administrative inspection, efficiency orientation, cooperative group effort, and research orientation. Table 1 reflects the organization of the development of teacher evaluation over time. 


\section{Table 1}

\section{Historical Development of Teacher Evaluation}

\begin{tabular}{|l|l|}
\hline $\begin{array}{l}\text { Administrative Inspection } \\
1642-1875\end{array}$ & $\begin{array}{l}\text { Inspections conducted by committees or administrators to assure that } \\
\text { teachers followed the community's moral standards and managed the } \\
\text { school. }\end{array}$ \\
\hline $\begin{array}{l}\text { Efficiency Orientation } \\
1876-1936\end{array}$ & $\begin{array}{l}\text { Begins after the Civil War. A business ideology seeking efficient } \\
\text { workers and citizens. Research findings dictated selection of subject } \\
\text { matter and teaching methods. Supervisors informed teachers of the } \\
\text { findings and implications. }\end{array}$ \\
\hline $\begin{array}{l}\text { The Cooperative Group } \\
1937-1959\end{array}$ & $\begin{array}{l}\text { The Great Depression, women's rights, and the civil rights movement } \\
\text { prompt a shift to social, psychological, and educational policy. The } \\
\text { supervisor provides the teachers with a conceptual framework, with } \\
\text { teachers following the framework. }\end{array}$ \\
\hline $\begin{array}{l}\text { Research Orientation } \\
1960-\text { present }\end{array}$ & $\begin{array}{l}\text { Russia launches Sputnik. Seeking effective schools, the Educational } \\
\text { Reform Movement is spawned. Clinical supervision is developed by } \\
\text { Goldhammer (1969) and Cogan (1973). Further researchers } \\
\text { developed humanistic/artistic, technical/didactic and } \\
\text { developmental/reflective models. }\end{array}$ \\
\hline $\begin{array}{l}\text { Future Developments in } \\
\text { Teacher Evaluation }\end{array}$ & $\begin{array}{l}\text { Self and peer evaluation, sustained planning, culture and gender } \\
\text { issues, democracy, critical reflection, organic change develop in } \\
\text { response to teaching and learning challenges. The purposes of } \\
\text { teaching are refined to help students be critical thinkers. }\end{array}$ \\
\hline
\end{tabular}

In the earliest years of assessing schools (1642-1875), committees of clergy and community members inspected schools, and reported their quality to the community. As the number of schools expanded, regional inspectors inspected schools and filed a report. Later, schools grew to have several teachers, one considered the principal teacher (the origin of the word principal). School inspections continued, conducted by administrators. Later, the principal conducted teacher evaluation as quality assurance for administration and community. Teacher ratings and checklists continued through the Efficiency Orientation, Cooperative Group, and Research Orientation stages as primary activities. Clinical supervision, developed in the Research Orientation stage, involves the teacher with the purpose of making teacher evaluation meaningful. Emerging from the 
seminal work of Robert Goldhammer in the late 1960s and Morris Cogan in the early 1970s, clinical supervision is the most prevalent model of teacher evaluation (Nolan \& Hoover, 2004). This standardized, articulated approach includes goal setting, a preobservation conference, in-class observations, and a post-observation conference (Glickman \& Kanawati, 1998; Neville \& Garman, 1998; Smith \& Andrews, 1989). Teachers merely receive summative reports written entirely by their supervisors. This protocol is generally followed twice a year for probationary teachers. Checklists and observations inform this practice. Clinical evaluation processes are negotiated to assure fairness. Clinical evaluation assures due process, as presented by Salowe and Lessinger (2001):

At present, laws mandate this framework as a protection of the employment rights for public school teachers...due process consists of five elements: known expectations of what is required to be achieved, documented assistance in meeting the expectations, timely knowledge of results, feedback from the results to construct necessary corrective action, and many chances to be successful through repetition of all the previous elements. (p. 133)

Clinical supervision is difficult to change because it meets due process demands and is included in legislation. In clinical supervision, the principal completes a summative, yearend report; the teacher can sign the evaluation report, elect to not sign, or write a response to the personnel file. The teacher is powerless to shift or annul the evaluation. In most teacher evaluation, the principal has all the power — the teacher has all the vulnerability.

Most teaching and evaluation still happen in isolation: one teacher with students or one teacher with one evaluator. Research shows that teacher evaluation focuses inordinately on what evaluators see teachers doing and not enough on what students are learning (Iwanicki, 1998; Nolan \& Hoover, 2004). Yet, few researchers call for change in 
teacher evaluation. As Peterson (2000) reported, “Administrator evaluation of teachers enjoys strong acceptance by precedent. After all, this is the way teachers have been evaluated in this country for well over 100 years” (p. 204). At its best, administrative observation in supervision practices is unlikely to capture true teaching quality; the observer will rarely see the best or worst of teaching.

Some researchers have recently proposed changing teacher evaluation. Consider Table 2, developed using the work of Starratt and Howells (1998):

Table 2

Traditional to New Supervision

From

Traditional Supervision $\rightarrow \quad$ New Supervision

Control

Empowerment

Separate functions

Integrated Functions

Sameness

Diversity

Occasional supervision assistance

Continuous collegial support networks

Applied Science

Professional inquiry

Mechanical Change

Organic Change

"If empowerment works where control has failed, the paradigm shift is most likely to accelerate emphatically. There are at least six transitions to be examined in beliefs about supervision, teachers and change in the relationships found within schools" (Starratt \& Howells, 1998, p. 996).

The shift from traditional to new supervision places more importance on the effects of a changing populace, the complicated nature of teaching, professionalism of teachers, and the need to continually improve schools. To move to new models of supervision requires a departure from lockstep practice. These changes are difficult to realize as a result of resistance to change, politics and lack of resources, including time 
and money. There are several representations of these changes, but few places where these new approaches are in use. In this time of continual change in school, new supervision could guide teachers' growth while addressing accountability. For instance, teachers viewing student outcomes may commit to changing in new ways, when using transformative or new evaluation practices to guide their praxis with students.

Another representation of change calls for a move from traditional to transformative supervision. This framework includes professional development, teacher practices, supervision, and relationships. It calls for collaboration. Transformative evaluation is at the new frontier of supervision. Perhaps most importantly, this approach acknowledges that teaching is complex and uncertain. It lessens isolation, connects teacher efforts to school improvement, and considers diversity. It calls for new behaviors on the part of principals and teachers. Administrators need to act as partners with teachers, build trust, and seek ways to connect teacher evaluation to overall improvement. Teachers need to develop flexibility, changing to meet the needs of students. This is the model that this problem based learning dissertation project most closely explores. Similar to Starratt and Howells (1998), Wood (1998) compared traditional and transformative supervision and evaluation. This contrast is represented in Table 3.

Transformative evaluation shows high regard for teacher knowledge and calls for teachers to self evaluate. Another author, Pajak (2000), aptly described the contrast between traditional and emerging practice in evaluation and supervision. He described the family of supervisory practices closely related to transformative work as developmental or reflective: 
These models are sensitive to individual differences and the organizational social, political, and cultural contexts of teaching... (they) call for supervisors to encourage reflection and introspection among teachers in order to foster professional growth, discover context-specific principles of practice, and promote justice and equity. (p. 280)

Table 3

Differences between Traditional and Transformative Supervision

\begin{tabular}{|l|l|l|}
\hline & Traditional & Transformative \\
\hline Teaching & $\begin{array}{l}\text { Mechanical. Can be observed and } \\
\text { judged by principal }\end{array}$ & $\begin{array}{l}\text { Complex and uncertain process. } \\
\text { Continuous decision making }\end{array}$ \\
\hline Supervision & $\begin{array}{l}1: 1 \text { interaction. The principal judges } \\
\text { and gives information to teachers }\end{array}$ & $\begin{array}{l}\text { Collaboration of teachers and principal. } \\
\text { Less isolation, more teacher reflection }\end{array}$ \\
\hline Who supervises & $\begin{array}{l}\text { Central control: principal, subject } \\
\text { matter, or central office }\end{array}$ & $\begin{array}{l}\text { Distributed. Teachers alone, groups of } \\
\text { teachers, specialist, the principal }\end{array}$ \\
\hline $\begin{array}{l}\text { Role of } \\
\text { supervisor }\end{array}$ & $\begin{array}{l}\text { Critic. Monitors and documents } \\
\text { using observations and evaluation }\end{array}$ & $\begin{array}{l}\text { Facilitator. Helps teachers with meaning } \\
\text { and risk taking. Finds time and resources } \\
\text { for teachers }\end{array}$ \\
\hline $\begin{array}{l}\text { Teacher-Super. } \\
\text { Relationship }\end{array}$ & $\begin{array}{l}\text { Hierarchical, principal as expert who } \\
\text { judges and advises }\end{array}$ & $\begin{array}{l}\text { Teachers and principal collaboratively plan } \\
\text { improvement }\end{array}$ \\
\hline $\begin{array}{l}\text { Type of } \\
\text { Evaluation }\end{array}$ & $\begin{array}{l}\text { Summative - captures a point in } \\
\text { time }\end{array}$ & $\begin{array}{l}\text { Formative - self and peer evaluation, } \\
\text { collegial striving for clarity }\end{array}$ \\
\hline Assumptions & $\begin{array}{l}\text { Principal knows better. External } \\
\text { research dictates teacher actions. }\end{array}$ & $\begin{array}{l}\text { Teachers have knowledge. Improvement } \\
\text { plans account for teacher and student } \\
\text { characteristics and ability }\end{array}$ \\
\hline $\begin{array}{l}\text { Professional } \\
\text { Development }\end{array}$ & $\begin{array}{l}\text { Inservice workshops, conferences, } \\
\text { long-term consultants }\end{array}$ & $\begin{array}{l}\text { Many opportunities. Teachers create, } \\
\text { experience and learn from other teachers in } \\
\text { the school }\end{array}$ \\
\hline $\begin{array}{l}\text { Policies of } \\
\text { Supervision }\end{array}$ & $\begin{array}{l}\text { Quality control, controlling or } \\
\text { directing teacher work }\end{array}$ & $\begin{array}{l}\text { Capacity-building to develop teacher } \\
\text { facilitation of learning and response to } \\
\text { challenges }\end{array}$ \\
\hline
\end{tabular}

Supervisors and teachers need to take risks in a supportive environment, if they

are to move toward justice and equity. The attributes required for emerging supervisory practice to be successful are complex. Pajak (2000) compared and contrasted views used 
in established and emerging (new or transformative) supervisory practice. Table 4

reflects the contrasts of views in the transformative and traditional approaches.

\section{Table 4}

Views from Established to Emerging Practice

\begin{tabular}{|l|l|l|}
\hline & Established Practice & Emerging Practice \\
\hline View of Learning & $\begin{array}{l}\text { Predictable, standard procedures } \\
\text { and outcomes }\end{array}$ & Complex and differential \\
\hline View of Teaching & $\begin{array}{l}\text { Mastering simple effective routine } \\
\text { behaviors }\end{array}$ & Exercising informed reflective judgment \\
\hline View of Supervision & $\begin{array}{l}\text { Reinforcing prescribed teacher } \\
\text { behaviors and skills }\end{array}$ & $\begin{array}{l}\text { Helping teachers discover and construct } \\
\text { professional knowledge and skill }\end{array}$ \\
\hline $\begin{array}{l}\text { View of Professional } \\
\text { Knowledge }\end{array}$ & $\begin{array}{l}\text { General teaching methods context } \\
\text { and content free }\end{array}$ & $\begin{array}{l}\text { Practice is dependent on context, subject } \\
\text { and responsive to individuals }\end{array}$ \\
\hline $\begin{array}{l}\text { View of Teachers and } \\
\text { Supervisors }\end{array}$ & $\begin{array}{l}\text { Isolated and independent } \\
\text { technicians }\end{array}$ & $\begin{array}{l}\text { Collegial team members, mentors and } \\
\text { peer coaches }\end{array}$ \\
\hline $\begin{array}{l}\text { View of Schools } \\
\text { Bureaucratic teaching } \\
\text { organizations }\end{array}$ & $\begin{array}{l}\text { Democratic teaching and learning } \\
\text { communities }\end{array}$ \\
\hline
\end{tabular}

Reflection and introspection require an environment of commitment and trust.

Trust builds with congruence between statements and actions. Trust grows in an

environment that values teachers as professionals. In fact, this environment is necessary to support transformative reflection that examines deeply held beliefs (Costa \& Kallick, 2000b). Exploration of these beliefs is uncomfortable, and will not promote equity on its own. Pajak’s (2000) work is aligned with Knowles’ (1984) work in adult learning theory. Knowles has the belief that adults must participate in their own learning and growth; they can serve as resources to themselves and others. Teachers hold answers; they can be empowered in a school environment if certain practices are in place. 
Recent developments in the field of teacher evaluation also address adult learning engagement, and include peer coaching, cognitive coaching, portfolio development, three-minute walk-throughs (Downey, Steffy, English, Fraise. \& Poston, 2004), multiple measures, using rubrics to assess a proficiency level, using testing outcomes to measure teaching effectiveness, national teacher certification processes, and other provable measures. Current approaches do not allow teachers the right and responsibility to conduct their own evaluation and evaluate their own teaching. Nor do these approaches call for the examination of teacher belief systems, the ability to be effective reaching across difference, or continuous improvement behaviors of trust, risk taking, and inquiry (Costa \& Kallick, 2000c). Although moving beyond traditional models, these processes still do not specifically address sustainable, whole school reform.

\section{Teacher Evaluation and School Reform}

At its best, teacher evaluation can be formative, supporting teacher development and whole school improvement. If formative, teacher evaluation can lead to substantive teacher growth, enhanced student outcomes, and school improvement focused on student learning (Danielson, 2002; Iwanicki, 1998; Nolan \& Hoover, 2004; Peterson, 2000). Conversely, teacher evaluation can be a ritualized, power-laden, mandatory, rulegoverned experience (Duke, 1995; Palmer, 1997; Peterson, 2000). In most teacher evaluation practices, teachers play the role of factory workers in a quality-assurance model - to be monitored.

To impact a whole school, teachers need to be less isolated, treated as professionals, and afforded opportunities to share. Most teachers do not observe other 
teachers teaching; they often see other adults only at lunchtime (Short \& Greer, 2002). Naming isolation and the poorly defined process, Palmer (cited in Peterson, 2000) concurred, "Consider the way teaching is evaluated. When we cannot observe each other's teaching, we get evaluation practices that are distanced, demoralizing, and even disreputable....Teachers have every right to be demoralized by such a simplistic approach” (p. 142). This demoralization of teachers can be pervasive in schools facing challenges. Heisinger's (1994) study focused on what teachers recognized as important in their own professional development. Teachers reported the following aspects, listed in descending order of importance: self-actualization, social, basic, status and security needs (Heisinger, 1994, p. 3). Heisinger recommended, “Staff development activities should incorporate opportunities for collegial interaction among teachers” (p. 233). Similarly, the interview study of Kauchak et al. (1985) found that teachers believe principal supervisory visits are perfunctory, brief, infrequent, not applicable, a nuisance, and not rigorous. Teachers find evaluative visits helpful when principals reassure and support them, or when they believe the principal has expertise. Otherwise, evaluative visits did not improve instruction.

Overcoming isolation, moving from a preoccupation with inspection toward facilitated growth, from a micro to a macro conceptualization of supervisory context, and creating community are essential to effective teacher evaluation practice (Glickman \& Kanawati, 1998). Adams and Kirst (1999) proposed suggestions about how evaluation can change,

Leaders need to break up the atomistic accountability of teachers operating behind classroom doors. Isolated teachers do not discuss what teachers are collectively 
accountable for, thus they cannot participate responsibly in school (and state) efforts to improve student achievement. (p. 486)

Opening the doors and the walls between classrooms and allowing space to talk about teaching in sustainable ways requires committed leaders working openly with teachers in continuous collegial exchange. Schools are often loosely coupled systems with inherent teacher isolation; building shared leadership in schools is a novel and connecting idea.

Professional learning communities build shared leadership skills. In professional learning communities, teacher leaders gather staff input and entertain all ideas, even if they initially seem absurd. They collaboratively identify ideas to keep and those to discard (Blankstein, 2004). They routinely plan and set goals, openly review actions and then set new goals in a continuous improvement cycle (Chenoweth \& Everhart, 2002; Costa \& Kallick, 2000c). Sergiovanni (1995) termed this leadership density and Lambert (1998) termed it leadership capacity. Collaboration requires learning about leadership and taking actions congruent with desired outcomes (Greenfield, 2004). Studying leadership characteristics of principals, Blumberg and Greenfield (1980) included the following attributes: communication, vision, initiative, comfort with risk, data analysis, energy, and determination. These attributes describe all school leaders, from principal to custodian. Increased leadership density can help schools navigate the dips and valleys of change.

At the center of the assumptions of this study is the assertion that teachers involved in the study are high performers. That is, they are of contract status and have been involved in school improvement efforts. They may serve as department chair or as a member of a school improvement committee. They gladly extend themselves to take on 
new tasks, if the tasks support the improvement of school for students, colleagues, or the school community. These teachers seek to improve their ability to reach students, to learn about their own practice and to self evaluate. It is this context and commitment that stretches the teacher to become a teacher leader in a classroom or school environment.

Teacher leaders are continually working to improve. Teachers and school leaders reflect on their mission, goals, practices, and results. They collect, create, survey, analyze, and review documents and student outcomes. This process has been represented as a spiral in the Purhepecha culture of Mexico, and in many other cultures since ancient times. The spiral as a representation suggests that there is no beginning and ending point, but that improvement is continuous and recursive. It allows for implementation dips, or for progress that is not always linear. In extending the model further, the spiral could operate like a double helix. Pairs or groups of teachers can see where they are, look back at what they have accomplished, and set goals for the future.

The Spiral Model is a schema that represents a commitment to continuous improvement, and offers a visual representation of collaboration in school improvement. Figure 2 is an adaptation of a spiral developed by Chenoweth and Everhart (2002).

Even though communities engaged in school improvement experience setbacks, the spiral allows a person or group to assess where they are, reflect about where they have been, and set goals for the future. When feedback loops work, staff sees evidence that their input is valued. The more revolutions they make in a reflective pattern, the more familiar the process. In time, trust builds and reflection becomes a part of the organization's predictable patterns of behavior leading to change. Gardner (1999) supported this idea, "Unless one has the opportunity to think about what one is doing and 
to reflect on what went well, what went poorly and why, chances for a long-term improvement curve are slight” (p. 232). Teachers working in collaborative, reflective cycles as professionals can sustain personal and whole school change over time. Professionals exert control over the way they are evaluated; workers do not (Kauchak et al., 1985). From isolated to shared reflection, from a point in time assessment to continuous improvement, from alienation to community, teacher evaluation practice must shift.

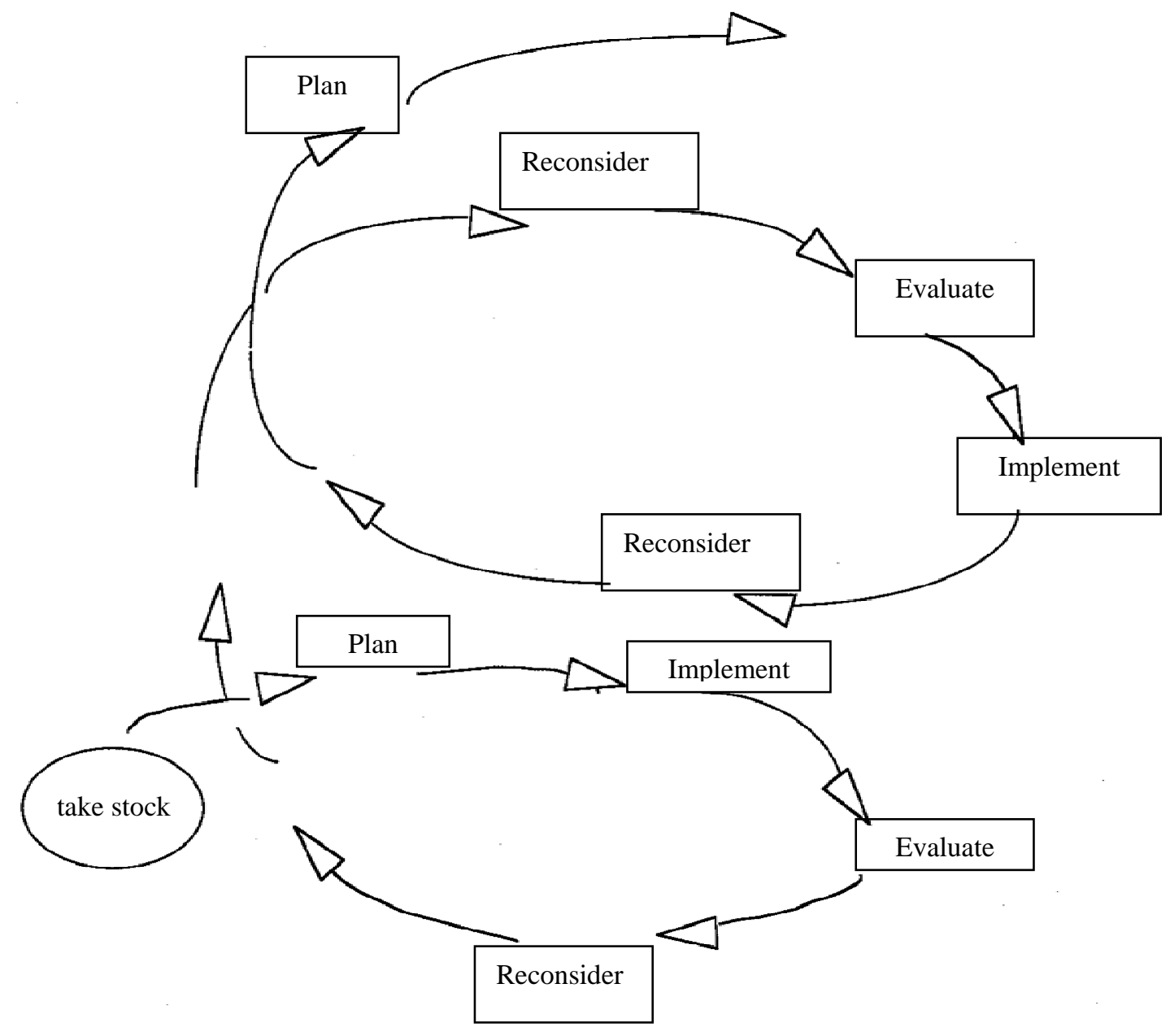

Figure 2. Spiral Model of Continuous Improvement. 


\section{Structural Frameworks and Teacher Evaluation Goals}

To guide teacher evaluation, school districts generally author a set of stated values in partnership with local teacher unions and agree on criteria reflective of sound teaching. Sound teaching or good teaching is complex and hard to capture with one list guiding a few observations in clinical evaluation. Unfortunately, there is not one clear answer about what good teaching is. Various authors have identified the characteristics of an effective teacher, and each researcher often has his or her own list. Following is a sampling of these attributes:

- Instructional strategies, classroom management, classroom curriculum design (Marzano, Pickering, \& Pollock, 2001).

- Instruction, classroom management, disciplinary interventions, student socialization (Good \& Brophy as cited Nolan \& Hoover, 2004).

- Planning, setting goals, instruction, classroom management and organization, teacher-student interactions, equity, assessment (Cotton, 2000).

- Grouping procedures, teacher behaviors, curriculum (Creemers, 1994). Classroom management, instructional strategies, and classroom curriculum delivery appear to be the most common attributes of teachers demonstrating excellence. Cotton (2000) added student-teacher interactions, equity and assessment. The addition of these three attributes is essential for schools experiencing challenges of being effective across diversity. Still covering the same basic list of classroom management, instructional strategies and classroom curriculum delivery, Iwanicki (1998) and Ribas (2002) added the following traits: 
- The teacher promotes a positive learning environment

- The teacher engages the students in meeting lesson objectives

- The teacher effectively manages routines and transitions

- The teacher creates a structure for learning

- The teacher uses appropriate questioning techniques

- The teacher communicates clearly, using precise language and acceptable oral expression

- The teacher monitors student learning and adjusts teaching when appropriate

- The teacher performs non-instructional duties

- The teacher assumes responsibility for meaningful professional growth

- The teacher assumes leadership for school improvement and professional growth

- The teacher promotes equitable opportunities for student learning

This view expands to define effective teaching and includes out-of-class responsibilities, student engagement, equity, professional growth, and school improvement.

Curious about what teachers value most, Smith (1992) conducted a quantitative study of effective middle school teachers. Smith was curious about what expert teachers would report. Smith's results identified the following factors as most critical to maintaining effective middle school teaching:

- Being able to balance academic and affective concerns

- Having a genuine liking, commitment and empathy for the early adolescent

- Ability to use a broad repertoire of teaching and learning strategies

- A concerned, listening principal who knows how to take action 
- Team compatibility and commitment and adequate planning time

- A strong belief in the advisory concept and ability to develop trust

- Participatory choice and teacher involvement in staff development

- A thorough knowledge of early adolescent needs and development

- Multiple exposure to and extensive experience with early adolescents during preteacher training.

These factors are tailored to the middle level learner. This list goes deeper, including beliefs and structures to engender success. Interesting factors that teachers mentioned is a principal leader, as well as the importance of trust.

To create democratic schools where justice matters, we have a moral calling to align everything we do to that end. The key idea is to keep essential activities aligned to our central core values and discard efforts not so aligned (Fullan, 2005). Can the attributes of effective, expert teachers be determined and increased? Can educators create the beautiful, democratic education needed by all students?

Justice and equity are difficult to realize, but are morally compelling; they make democratic schools possible. Giroux and Giroux (2004) declared, “A substantive democracy simply cannot exist without educated citizenry” (p. 6). Attributes crucial to closing the achievement gap and improving schools experiencing great challenge are proposed by Apple and Beane (1995) as central concerns of democratic schools:

- The open flow of ideas, regardless of their popularity, that enables people to be as fully informed as possible.

- Faith in the individual and collective capacity of people to create possibilities for resolving problems.

- The use of critical reflection and analysis to evaluate ideas, problems and policies. 
- Concern for the welfare of others and "the common good".

- Concern for the dignity and rights of individuals and minorities.

- An understanding that democracy is not so much an "ideal" to be pursued as an "idealized" set of values that we must live and that must guide our live as a people.

- The organization of social institutions to promote and extend the democratic way of life. (pp. 6-7)

These attributes call for educators to engage at deep levels; they are not quick fixes or magic bullets. Apple and Beane (1995) called for educators to live their values, trust each other, be responsible for their own learning, work with other organizations, and commit to the good of all. In short, fully engaged educators with high commitment and trust are needed to make democratic schooling happen for all students. Unless a safe, engaged, economically supported and focused way of thinking about education can be realized within public schools, it is not likely that democratic and beautiful learning can happen for all students.

\section{Ethical Considerations}

To fully commit to being transformative, democratic educators require a deep, loving commitment to all students, other educators, families, and the community. Commitment drives the will to strive for excellence, know our colleagues and students, build trust, know ourselves, teach with rigor and help students become critical thinkers.

"Teaching, like any human activity, emerges from one’s inwardness, for better or worse” (Palmer, 1997, p. 15). This is commitment to far more than a job; it is a lifelong quest.

Shared language makes reflecting with specificity about improving classrooms possible (Saphier, 1993). Shared language also removes the direct communication from one communicator to the other and gives them a shared vocabulary. Whether using 
rubrics (Danielson, 2002), a diagram (Iwanicki, 1998), or the habits of mind (Costa \& Kallick, 2000a), shared language enables people to engage in deeper conversations. Not only is a shared vocabulary essential, but trust, confidentiality, and active listening must be in place before an open environment for dialogue can emerge.

The following list is from the work of Wheatley (2002). She presented guidelines for respect in dialogue:

- We acknowledge each other as equals

- We try to stay curious about each other

- We recognize that we need each other's help to become better listeners

- We slow down so we have time to think and reflect

- We remember that conversation is the natural way humans think together

- We expect it to be messy at times. (p. 29)

Dialogue requires commitment and practice. Sharing explicit beliefs, deep level reflection, honesty, shared language, and commitment to high levels of trust, holds hope to help us improve teaching and education. To gain the level of trust needed will require time and space to learn each other deeply. In a school setting, dialogue about our teaching practice can turn a whole school into a learning lab for teachers improving their praxis. Dialogue with students holds a similar promise.

Before we can learn another, it is important that we examine our selves - our identity and all the experiences we have had that influence how we interact in the world. Spindler and Spindler (1994) defined the self as the enduring self, the situated self and the endangered self. The enduring self is made up of deeply held beliefs and long term experience. The situated self can be likened to an everyday role, such as the teacher role in the school. The endangered self develops if the situated self conflicts deeply and often with the enduring self. Teachers and students operate with these complex selves on a 
daily basis. Once we know our selves deeply, understanding another's experiences and gaining empathy is more possible. Wink and Wink (2004) depicted how the enduring self informs our human experience and determines the lenses we use. Reflecting on Wink and Wink’s work, the Mind's Eye Model was developed (see Figure 3).

From our earliest existence, all communication and life happens within a cultural, spiritual, political, economic context. Shared beliefs determine how age, gender, education, and ethnicity influence group members. It is only when we know our values, value others and value difference as strength that beautiful education become possible.

To increase trust in all interactions in school, power must shift from power over to exploration with (Freire, 1973, pp. 40-41). Power-sharing praxis involves all voices, builds leadership density, and affects change (Bergmann, Hurson, \& Russ-Eft, 1999; Foster, 1986; Sergiovanni, 1995). When a school values risk taking, teachers, students and others can risk changing taboo aspects of their work; they may create a beautiful education. Shared reflection everywhere requires what Shields (2003) expected of leadership commitment to dialogue:

It will be the task of each transformative leader...to create the norms of continuous dialogue - in the halls, in the staff room, at staff meetings, by disseminating articles, by a judicious comment or a strategically posed question in daily e-mail, by encouraging teachers to attend workshops and classes and engage in peer observations or team teaching. The possibilities are endless. Although many serendipitous understandings may emerge from these interactions, dialogic moments should also be intentional, designed to support the agreed-on norms of the community. (p. 290)

Dialogue can make all aspects of education discussable (Freire, 1973). Researchers encourage us to consider that all daily actions of educators in schools determine the goals schools can reach (Danielewicz, 2001; Greenfield, 2004). In other words, each step can lead us closer to our goals, if we make decisions with focus and sustained effort. 
Mind's Eye Model

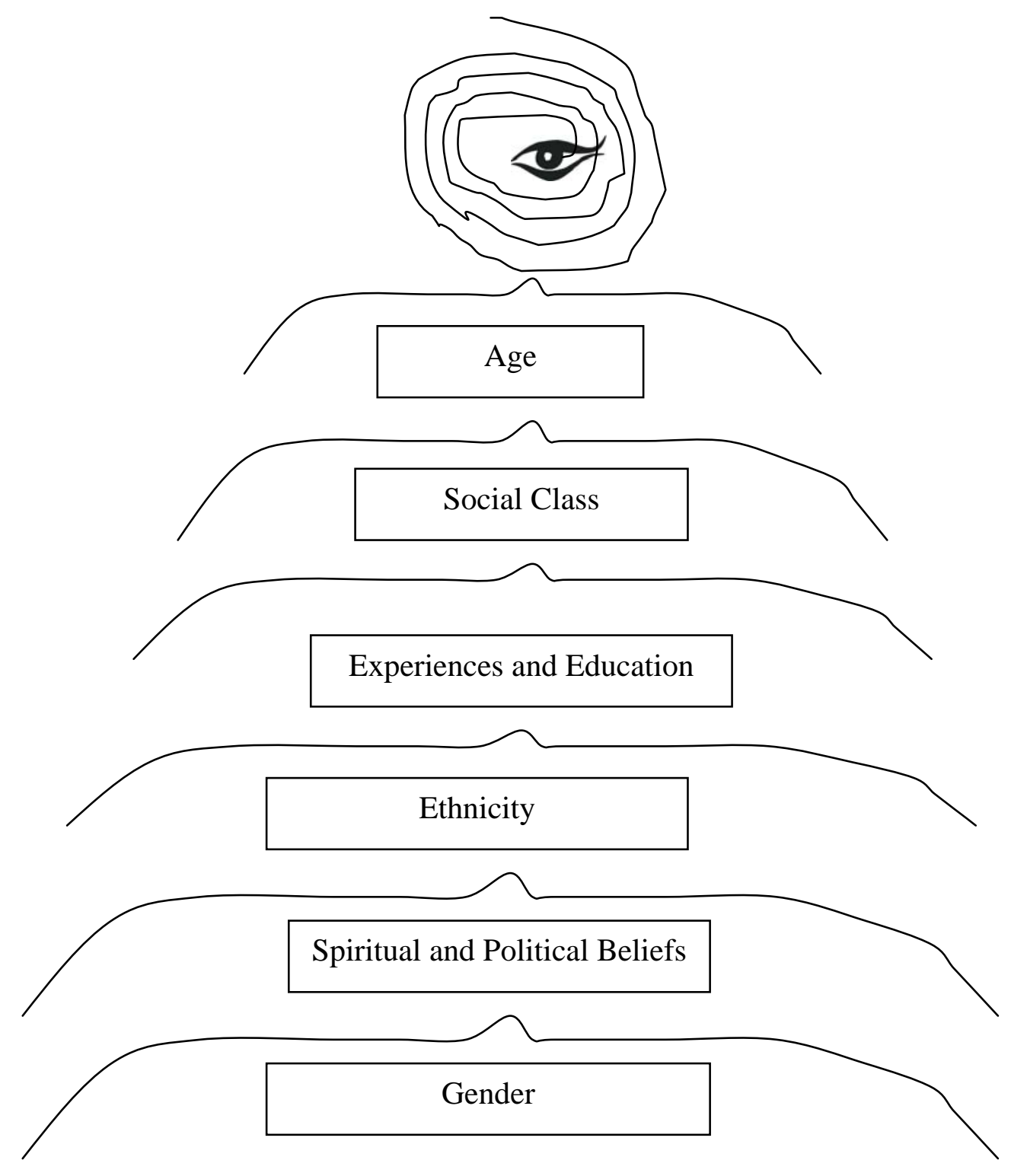

Figure 3. Mind's Eye Model.

Trust in relationships and communication is foundational to all learning (Blumberg \& Greenfield, 1980; Chenoweth \& Everhart, 2002; Freire, 1973; Greenfield, 
2004; Nolan \& Hoover, 2004). Trust builds when people exhibit integrity, honesty, character, reliability, and competence with each other consistently over time (Freire, 1998a; Stillwell, 2003). Trust can be elusive, not only among adults but in the classroom. Anyon (1997) lamented, "students whose home circumstances are extremely stressful... make many of them restless and confrontational; they can be difficult to teach, and to love” (p. 28). Democratic education calls us to look below the surface, at deep levels. This act aligns to Nieto's (2003) inclusive definition of multicultural education:

Based on the assumption that students of all backgrounds and circumstances are capable of learning and achieving, anti-racist basic education permeates all areas of school and for all students, encompassing not only race, ethnicity and language, but also gender, social class, sexual orientation, ability and other differences. Moreover it is accompanied by a deep commitment to social justice and equal access to resources. (p. 17)

Teachers who believe that students can respond to rigor, relationship, and relevance love their students and subjects in inclusive ways. These teachers engage in praxis and hold high expectations for themselves and for all students.

Increased cultural competence helps people value difference; teachers must believe students of poverty have value (Payne, 1996). Without the belief that students have value, teachers are unlikely to demand and exude excellence from students. They are more likely to view minority students or students experiencing poverty as less than other, more privileged students. Bartolome (1996) urged teachers to reflect when he aptly wrote, "Teachers must confront and challenge their own social biases so as to honestly begin to perceive their students as capable learners” (p. 239). To know others, teachers must understand their own cultural competence, and seek to increase it. Once their values are explicit, teachers can strengthen their care for students in sustainable ways (Fullan, 2005; Noddings, 1992; Nolan \& Hoover, 2004). Teachers can compel themselves to 
teach the middle class rules needed by students in school (Delpit, 2002; Payne, 1996).

Anti-racist education requires educators to develop cultural competence. This

commitment to valuing cultural differences and students of difference is key to student performance, engagement, and outcomes.

Robins, Lindsey, Lindsey, and Terrell (2002) represented the stages of cultural competence in Table 5.

\section{Table 5}

\section{Shifting toward Cultural Competence}

\begin{tabular}{|c|c|c|c|c|}
\hline \multicolumn{5}{|c|}{ Cultural Competence } \\
\hline Cultural & Cultural & Cultural & Cultural & Cultural \\
\hline Destructiveness & Incapacity & Blindness & Precompetence & Competence \\
\hline \multicolumn{5}{|c|}{$\begin{array}{l}\text { Cultural destructiveness: Elimination or suppression of another cultural group or the culture's } \\
\text { practices }\end{array}$} \\
\hline \multicolumn{5}{|c|}{$\begin{array}{l}\text { Cultural incapacity: Treatment of non-dominant groups based on stereotypes. The belief is that the } \\
\text { dominant group is inherently superior. }\end{array}$} \\
\hline \multicolumn{5}{|c|}{$\begin{array}{l}\text { Cultural blindness: Failure to see or acknowledge that differences between groups often make a } \\
\text { difference to the groups and the individuals who are members of the groups. }\end{array}$} \\
\hline \multicolumn{5}{|c|}{$\begin{array}{l}\text { Cultural precompetence: Behavior or practices to acknowledge cultural differences in healthy ways } \\
\text { but that are not quite effective. }\end{array}$} \\
\hline \multicolumn{5}{|c|}{$\begin{array}{l}\text { "Cultural competence: Effective interactions with individuals or groups from different ethnic and } \\
\text { social cultures; use of the essential elements as the standards for individual behavior and } \\
\text { organizational practice” (Robins, Lindsey, Lindsey, \& Terrell, 2002, pp. 94, 126) }\end{array}$} \\
\hline
\end{tabular}

This view combats a deficit view of students as at risk students or less capable. Cultural competent requires deep work. Consider the metaphor of the Iceberg (see Figure 4). The inner landscape of our lives lies below the surface. Only a small percentage is visible - above water. People can look below the surface. This process is not linear and requires changing our attitudes and views. What lies below the surface? 


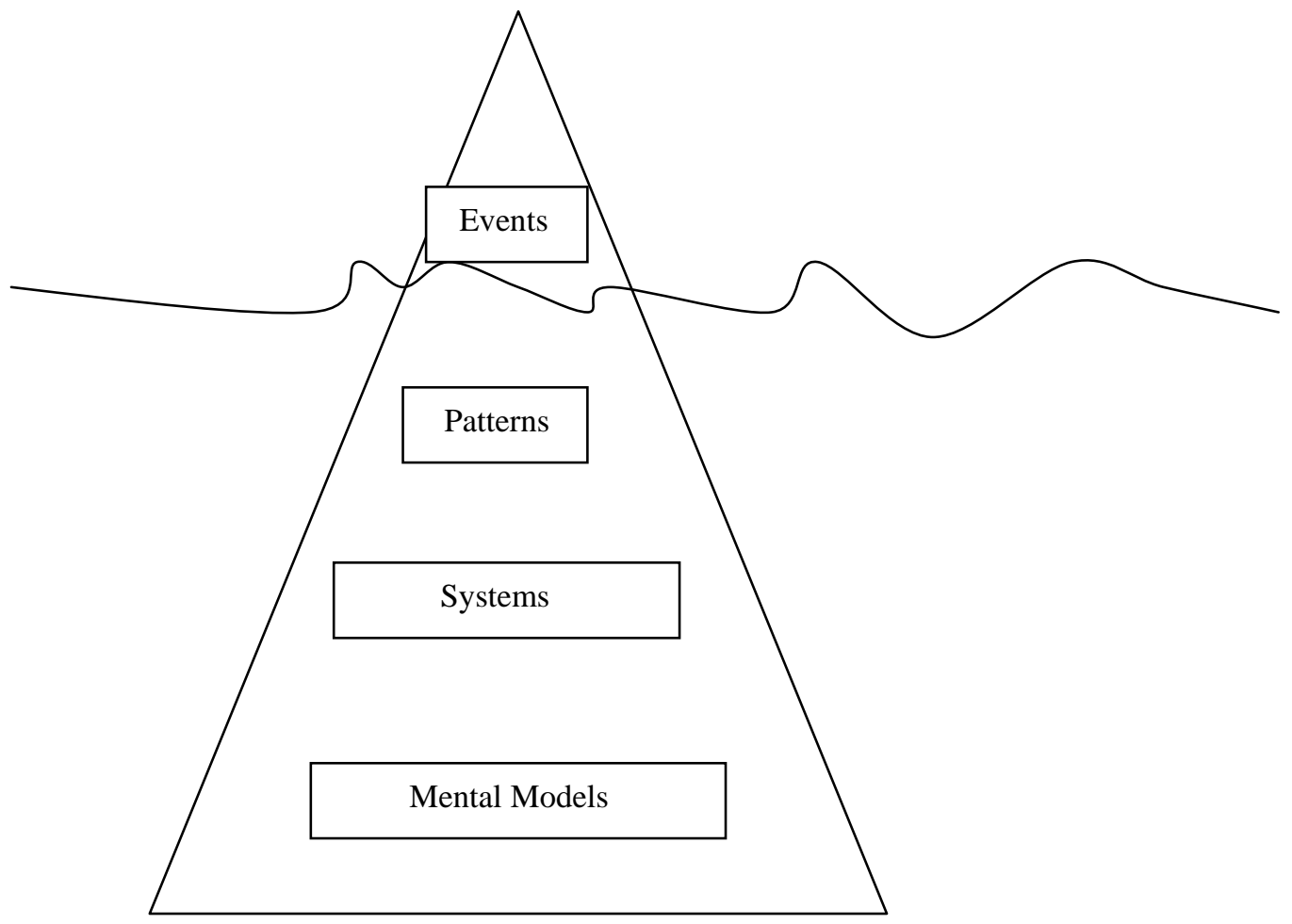

Events are observable and account for a small part of how we make decisions in any situation. Teacher evaluation observations only capture obvious information or activities. What was seen or heard? Knowledge is made up of concrete facts.

Patterns are events that repeat in similar ways, trends. We can chart behaviors over time to observe patterns. Examples in education are: behavior plans, tardy trends, or student tracking charts. These are measurable and reportable. Another example is a pattern of trustworthy behavior. What events predict what outcomes? How do we want the trend to change? Facts follow patterns and are organized by predictions observed in the past.

Structures are ways that we predict behavior. School examples are: the Master Schedule, hiring practices, leadership, evaluation, bell schedules, and rules. Structures predict what will or most likely will happen. What structure do we use in school - middle class expectations? What are the hidden rules of school? What interconnections produced the structure? What structures guide student realities? How can we optimize each student's learning? Is my classroom practice helping students to be their best?

Mental models are belief systems. Examples are love, humanism, cultural values, attitudes, ethnocentrism, history, trust, bias, moral purpose, consistency, commitment, openness to change, adherence to tradition, and integrity. One belief is that school improvement is continual, complex, and dynamic. What changes in mental models would produce improved patterns, trends, and events? Consider another perspective. What inferences do we make based on our mental models? What are strengths and weaknesses of different views? Learning happens from making abstractions, or understanding reality in a different way.

To work more effectively with others, we must look below the surface!

Figure 4. Iceberg Model of teacher reflection. 
Knowing themselves and understanding student reality are prerequisites to engaging with students. Teachers are morally compelled to know themselves. As Palmer (1997) posed:

We need to open a new frontier in our exploration of good teaching: the inner landscape of a teacher's life. To chart the landscape fully, three important paths must be taken - intellectual, emotional and spiritual - and none can be ignored. ... Good teachers share one trait: a strong sense of personal identity infuses their work. (pp. 15-16)

As Palmer put it, “Our task is to create enough safe spaces and trusting relationships... for our sake, the sake of our teaching and the sake of our students” (p. 15). Safety and knowing ourselves are two attributes of a class that are basic to trust and love. Teachers who commit to assuring love in the classroom make it possible for students to thrive.

A love ethic connects teachers and students; it encompasses care, commitment, trust, responsibility and respect in our daily interactions (hooks, 2000; Liston \& Garrison, 2004). Love is at the deepest level of human interaction. With love central to his definition, Freire (1998b) exhorted, "It is impossible to teach without the courage to love, without the courage to try a thousand times without giving up” (p. 3). Nieto (1999) expounded: “By ‘love,’ I do not mean a mawkish or sentimental demonstration of concern for students. Rather...love is at the core of good teaching, because it is predicated on high standards, rigorous demands, and respect for students, their identities and their families” (p. 100). Educators are discouraged from speaking about love in school. Education literature and practice is replete with other terms like respect, care, commitment, trust, or responsibility. Educators avoid deep connection, vulnerability, as well as accountability that would ensue if every teacher loved every student, 
orchestrating a classroom of high engagement, rigor, and love. hooks (2003) bemoaned a perceived danger of love in education, and wrote,

To speak of love in relation to teaching is already to engage a dialogue that is taboo. When we speak of love and teaching, the relationships that matter most are the relationships between the teacher and subject taught, and the teacher-student relationship.... Emotional connections tend to be suspect in a world where the mind is valued above all else, where the idea that one should be and can be objective is paramount. (p. 127)

To commit to love even when it is not widely discussed requires planned commitment. Love does not lend itself to provable, researchable, quantitative study methods. "Love is big. Love can hold anger, love can hold pain, and love can hold hatred. It's all about love” (White, 2004, p. 463). Critical educators, who have explicit knowledge of their own belief systems, seek justice, reach across difference to attempt to understand student identity, and then plan inclusive, courageous engagement to lovingly bridge the gap of difference partly responsible for the achievement gap. Educators are morally compelled to teach the hidden codes of school, and must assure that students are literate and can learn independently.

Political action is also taken to narrow the achievement gap and improve education for all students. However, some practices actually widen that gap. For instance, holding all students to the same outcomes without accounting for student abilities can doubly punish students who require the most growth to meet the outcomes. The next section discusses politics in relation to governing and determining teacher evaluation methods. 


\section{Teacher Evaluation in a Political Context}

Teacher evaluation is inextricable from political conflict as teacher evaluation is directed, articulated, and mandated by policy. In fact, education itself is political (Freire, 1998b). Schools reside in districts, within states, and ultimately answer to the federal government. Higher levels coordinate work at lower levels (Bolman \& Deal, 1997). At the building level, the principal establishes the values and judges the quality of teachers who work there. The principal is also under stress produced by higher levels such as the district or state that demand accountability.

Power is problematic in teacher evaluation; the principal financially affects the teacher. Principals recommend further employment, place improvement status, or termination (the ultimate negative repercussion). The principal's goal in teacher evaluation should be, as Dewey (1944) urged, to nurture open mindedness, whole heartedness, and intellectual responsibility. This kind of interaction is most possible with high performers, but principals have limited time to acknowledge good teaching (Peterson, 2000). Moreover, because high performers are self-motivated, the principal can trust the high performers to carry on independently. Conversely, low or nonperforming teachers require evaluations. They occupy the bulk of resources of time and money spent on teacher evaluation (Peterson, 2000). Principals prioritize an overwhelming range of tasks and must evaluate marginal or beginning teachers first. They lack time to nurture all teachers.

Notwithstanding, teacher evaluation must center on the interaction between teacher and learner. Darling-Hammond (1997) represented this complexity (see Figure 5). 


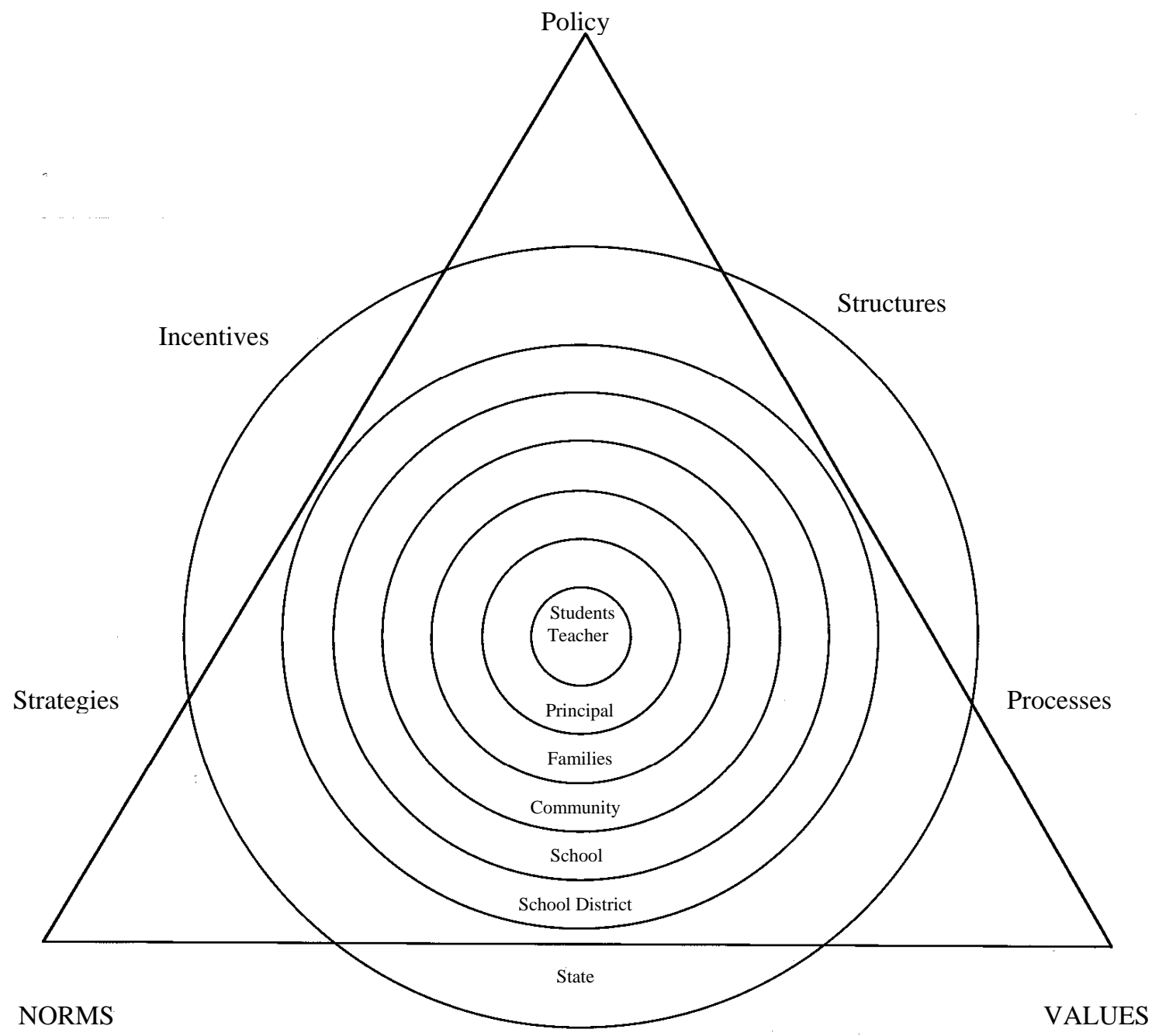

Figure 5. Student and teacher at the center.

If lacking focus, schools can lose student centricity as they strive to meet mandated outcomes - some funded and some not - at district, state or federal levels. Many influences impact teacher-student interactions. Because of the complexity of school, the focus on students and teachers in the classroom can lose urgency. Notice that Darling-Hammond (1997) included goals, values and norms, and situates all levels of support, all the way to policy, around the teacher and student interaction. Structures and 
beliefs guide decisions made by teachers, situated in the larger community. Critical leaders reexamine their actions and how they affect student outcomes and futures within society. The next section explores critical action needed to realize democracy in education as the goal of teacher evaluation.

\section{Critical, Democratic Education, and Evaluation}

Critical leadership in public schools makes a democratic education for all students possible (McLaren, 2003). When leaders share decision-making among all learning community members, leadership density increases. If actions are aligned with values, the group has a better chance to meet desired results (Greenfield, 2004; Sergiovanni, 1995). When teacher evaluation can seriously consider diversity as a part of the process as well as empower teachers in their own assessment, teachers gain in their commitment and power. Freire (1998b) illustrated respect situated in a transformative learning environment:

The more we respect students independently of their color, sex or social class, the more testimony we will give of respect in our daily lives, in school, in our relationships with colleagues, with doormen, with cooks, with watchmen, with students' mothers and fathers, the more we lessen the difference between what we say and what we do, so much more will we be contributing toward the strengthening of democratic experiences. (p. 90)

Transformational educators have exceptional impact on schools. To act consistently in alignment with one's values is only one aspect required of transformational leaders (Greenfield, 2004; Wheatley, 2002). Expanding this idea to teacher leaders can transform school with greater urgency. Transformational leaders motivate people to do more than originally expected to do by raising consciousness, building a team and focusing on higher order needs such as self-actualization (Lunenburg \& Ornstein, 2004, p. 177). It is 
imperative that our public schools create wonderful learning environments for children as they seek excellence.

Critical educators commit to more than excellence in education. Farahmandpur (2003) exhorted "Part of the pedagogical task of critical educators has to be linked to the larger social and political struggle for achieving economic democracy, human rights and social justice” (p. xv). Critical pedagogues examine policies to determine who receives instruction and to what level. Their interest is an urgent will to transform education for social justice, with the end goal that all individuals gain skills needed to cross political, cultural, racial and class lines and critically examine and make sense of the world.

Critical thinking acted out in the daily education arena is likely to help us close the achievement gap in struggling schools for all students. Reinforcing teachers who help all students achieve can help whole schools improve. Can this reinforcement happen in a sustained way through teacher evaluation?

\section{Chapter Summary}

School reform efforts pose challenges for the academic success of public school students. It is a complex journey, especially as outer urban and low-income schools become increasingly diverse. This quest requires a shared commitment to a professional learning community and dialogue in an environment of trust (Bohm, 1996; Freire, 1998b;

Fullan, 2005; Greenfield, 2004; Wheatley, 2002). Students who experience differences of mobility, class, race, and culture feel alienated from school. Even so, all students need to be able to critically think, love to learn, and negotiate the world (Littky \& Grabelle, 
2004). Even so, educators who love their students must be strong, connective, and lovingly angry about the achievement gap (Shields, 2003).

- In diverse public school settings, teacher engagement in reflective praxis is an integral component in their long-term continuous development (Costa \& Kallick, 2000d; Darling-Hammond, 2002; Duke, 1995; Freire, 1970; Gardner, 1999; Peterson, 2000; Sleeter, 2001). Innovative researchers believe that meaningful teacher evaluation can support professional development and whole school improvement (Danielson, 2002; Iwanicki, 1998). Honest, explicit, loving, rigorous teacher evaluation is one of the few tools not yet in the school improvement toolbox. How can teachers engage in loving ways with their subject matter, students, and each other in a sustainable rigorous way across differences of race, class, spiritual and cultural difference (Wink \& Wink, 2004)? How can teacher evaluation be meaningful? How can it contribute to improving school for all? Will teachers connect with their students across difference in new ways? Can high quality teachers be empowered to self evaluate, transforming their practice and school? Does transformative evaluation make a difference? 


\section{CHAPTER III}

\section{RESEARCH DESIGN AND METHODOLOGY}

This study used a problem-based learning model (Bridges \& Hallinger, 1995) to address a real problem in practice: how to make teacher evaluation meaningful for high performing teachers while simultaneously improving school for all students (Iwanicki, 1998). In this study, teacher-leaders were empowered to self-evaluate, a transformative evaluation approach (Wood, 1998). Ten high performing teacher leaders field-tested a self-evaluation handbook. Participating teachers were members of Lincoln's Leadership Team working on school improvement efforts in their 800-student, minority-majority middle school. This qualitative, critical study was the preliminary field test of the handbook and self-evaluation process. Study options were designed to help teachers reach historically underperforming students. These options were developed based on the idea that school essentially happens between the teacher and the student in the classroom (Darling-Hammond, 1997). The closer connection of teachers with students and the chance for teachers to reflect on their practice and student outcomes as tools to improve school were the underlying assumptions guiding study options. Teachers worked individually, in pairs and as a group, to shape the project.

A clinical supervision model was and remains in place in the district; it is generally effective for novice or struggling teachers. Not rejecting those practices, this study was concerned only with high-performing teachers who consider evaluation 
meaningless, or a waste of time (Peterson, 2000). This study operationalized the transformative idea that high performing teachers need to be empowered in evaluation (Pajak, 2000; Peterson \& Chenoweth, 1992; Starrat \& Howells, 1998; Wood, 1998). In many evaluation models, contract teachers can conduct minimally-defined professional development activities; teachers are still externally evaluated. The goal of this handbook and the project was to add to a multifaceted teacher evaluation system (Samaras \& Freese, 2006; Stronge \& Tucker, 2003). Self-evaluation in this study focused on two District goals:

-Teacher adapts methods to meet individual student learning needs, and -Teacher interactions with students are appropriate to the developmental and cultural norms of the students.

Using Starratt and Howells’ (1998) work, Table 6 compares traditional and new supervision.

Table 6

Traditional to New Supervision

\begin{tabular}{ll} 
From & \multicolumn{1}{c}{ To } \\
Traditional supervision & \\
\cline { 2 - 2 } Control & New supervision \\
Separate functions & Empowerment \\
Sameness & Integrated Functions \\
Occasional supervision assistance & Diversity \\
Applied Science & Continuous collegial support networks \\
Mechanical Change & Professional inquiry
\end{tabular}

"If empowerment works where control has failed, the paradigm shift is most likely to accelerate emphatically. There are at least six transitions to be examined in beliefs about supervision, teachers and change in the relationships found within schools” (Starratt \& Howells, 1998, p. 996). 
In this project, teacher leaders explored transformative self-evaluation (Wood, 1998). Transformative evaluation shifts from a mechanical summative description to a complex, formative process that builds teacher capacity, moves teachers central to their evaluation, and allows teachers to learn from and with each other. Teaching is a passion for high-performing teachers. Internally motivated, they are excited to learn all they can about their subject matter and to improve school for all.

This work exemplifies the family of evaluation approaches described by Pajak (2000) as developmental or reflective. As Pajak described:

These models are sensitive to individual differences and the organizational social, political, and cultural contexts of teaching... (they) call for supervisors to encourage reflection and introspection among teachers in order to foster professional growth, discover context-specific principles of practice, and promote justice and equity. (p. 280)

I heartily agree that promoting justice and equity are key. I yearn to offer high performing teachers opportunities to be fully supported and safe while they grow themselves. The move to context-specific principles of practice in this study should lead to increased justice and equity in the classroom. Teachers who are high performers yearn to help their students fully engage in the teaching-learning at hand. How we view various aspects of teaching and learning influence what we believe is possible and the inherent difficulty involved in realizing change in our practice.

Table 7 represents Pajak’s (2000) representation of the shift from established to emerging practice. 


\section{Table 7}

\section{Established to Emerging Practice}

\begin{tabular}{|l|l|l|}
\hline & Established Practice & Emerging Practice \\
\hline View of Learning & $\begin{array}{l}\text { Predictable, standard procedures } \\
\text { and outcomes }\end{array}$ & Complex and differential \\
\hline View of Teaching & $\begin{array}{l}\text { Mastering simple effective } \\
\text { routine behaviors }\end{array}$ & $\begin{array}{l}\text { Exercising informed reflective } \\
\text { judgment }\end{array}$ \\
\hline View of Supervision & $\begin{array}{l}\text { Reinforcing prescribed teacher } \\
\text { behaviors and skills }\end{array}$ & $\begin{array}{l}\text { Helping teachers discover and construct } \\
\text { professional knowledge and skill }\end{array}$ \\
\hline $\begin{array}{l}\text { View of Professional } \\
\text { Knowledge }\end{array}$ & $\begin{array}{l}\text { General teaching methods context } \\
\text { and content free }\end{array}$ & $\begin{array}{l}\text { Practice is dependent on context, } \\
\text { subject and responsive to individuals }\end{array}$ \\
\hline $\begin{array}{l}\text { View of Teachers and } \\
\text { Supervisors }\end{array}$ & $\begin{array}{l}\text { Isolated and independent } \\
\text { technicians }\end{array}$ & $\begin{array}{l}\text { Collegial team members, mentors and } \\
\text { peer coaches }\end{array}$ \\
\hline View of Schools & $\begin{array}{l}\text { Bureaucratic teaching } \\
\text { organizations }\end{array}$ & $\begin{array}{l}\text { Democratic teaching and learning } \\
\text { communities }\end{array}$ \\
\hline
\end{tabular}

I am excited by these new practices. When I was a teacher, I worked in isolation

to improve. Now as an administrator, I focus on novice or struggling teachers in the evaluation process; I have limited time and resources for teacher evaluation (Peterson, 2000). Akin to classroom management, $20 \%$ of teachers take $80 \%$ of teacher evaluation time. As an educator, I work to nurture open-mindedness, whole heartedness, and intellectual responsibility (Dewey, 1944).

This study implemented the 12 new directions that Peterson (2000) called for:

1.Emphasize, seek out, document and acknowledge good teaching...

2. Use good reasons to evaluate...

3. Place the teacher at the center of evaluation activity...

4. Use more than one person to judge teacher quality and performance...

5. Limit administrator role of judgment...

6. Use multiple data sources...

7. When possible, include actual pupil performance data...

8. Use variable data sources to inform judgments...

9. Spend time and resources to recognize good teaching...

10. Use research on teacher evaluation correctly... 
11. Attend to sociology of teacher evaluation...

12. Use results to encourage and professional dossiers, publicize aggregated results, and support teacher promotion systems. (pp. 4-11)

Making teacher evaluation meaningful is urgent. High-performing teachers may be more realistic and comprehensive if they evaluate their teaching (Peterson \& Chenoweth, 1992). One senior teacher reported, "I have been here 10 years. I was evaluated once and only once - in my first year. The teacher evaluation system for good teachers is a joke.” Interestingly, he requested an evaluation this year, time permitting. Another colleague requested an additional observation, saying, “ I trust you and want your feedback. I want to learn more about my teaching.” She also mourned her isolation in her classroom, although she is a leader in her subject area.

Teacher expectations of students changed during this study. Teachers engaged in the off limits reflection Howard (1999) suggested, “to encourage White educators to look deeply into the nature of dominance, to understand the... tragic impact it has in the lives of our colleagues and students” (p. 68). Teachers learned from and with each other, and considered democratic practice with every study model. They remained open and reflective, even when the topics at hand were difficult and presented needed changes.

\section{General Design}

Problem based learning considers a problem in practice that has few specific variables that can be manipulated in a quantitative way. Multiple choice testing does not work in this problem-based learning. In fact, this study was, by design, ill structured to allow for input and change in the study. Built-in ambiguity was needed so that experiences could stimulate learners to find multiple solutions. Ambiguity led teachers to 
freely reflect on their teaching praxis, gather artifacts, measure their own effectiveness, and change (Freire, 1970). Because it asked an initial question and did not test an initial hypothesis, this project was a qualitative study structured to capture emergent learning.

All teachers participating in this study were volunteers. They were recruited by the researcher, and exhibit the following characteristics:

- Hold contract status

- Participate in one or more school-wide improvement efforts

- Wish to re-examine and improve their teaching

- Commit to journal, meet in a learning group and complete two study options

- Have consistently received exemplary summative evaluations in the past

Ten teachers volunteered, and committed to the study. All 10 completed the study.

\section{Research and Development Cycle: The PBL Self Evaluation Handbook}

Research and development of the initial draft handbook took place over a twoyear period (2007-2009). Over half of the leadership team members wanted to try a new approach to teacher evaluation. They used continuous improvement and professional learning community strategies. They are skilled at using data to make decisions regarding school improvement. They wrote the school's School Improvement Plan for several years running. Five teachers suggested changes to the draft handbook to prepare for the preliminary field test. The pilot field test occurred from September 2009 through March 2010. Teachers were, and continue to be, invested in this work.

As the 2009-2010 school year closed last year, their summative evaluations were consistently perfunctory, and did not inspire their teaching practice. It was just more of 
the same. Literature shows that year after year, teachers and supervisors survive just one more year of meaningless, gold star awarding evaluation interactions Peterson (2000).

\section{Preliminary Field Test}

Participating teachers piloted a new teacher evaluation handbook and self assessed. They pre-assessed their teaching using a self-survey, recorded their experiences in a journal, and selected at least two options to frame their reflection during the study. Teachers chose study options designed to help them connect with traditionally underperforming students, examine teacher and student identities, reflect on their own practice, and measure outcomes. Teachers rejected traditional options, and used transformative study models that helped them reflect at a critical level. Each transformative option was tested for its efficacy in increasing student engagement, and teachers used multiple measures, including teacher made assessments, to determine outcomes shown by students.

At least two teachers selected each study option and engaged in a high degree of collaboration with others. These teachers acted as supportive colleagues. Each teacher remained in control of his or her own evaluation.

The entire study group met together in four learning sessions. Each session allowed time for teachers to share their self-study experience. These sessions served as problem solving opportunities for teachers as a group. As the study ended, teachers presented their learning projects, conducted exit self-surveys and set two to three goals for their future improvement. 
Throughout the study, teachers were supported with time and resources. I was the researcher. At the onset, I was the principal of the school. I then became the English Language Development Coordinator and subsequently became the Federal Programs Director. As I was not the direct supervisor of the teachers, this built in additional safeguards for teachers

During the culminating events, teachers described their study experience to the pilot study group. Throughout the study, teachers shaped and revised all study aspects. Participants revised the handbook (product) and developed their own processes within the models for self-evaluation. All transcripts, the handbook and study options were available to all teachers for their review and revision.

One area of inquiry was to find out to what degree teachers would shape the process, control their learning and change the handbook or its processes. A second research question was to find out if teachers would self evaluate in a collaborative process to improve their teaching, thus tying professional development to teacher evaluation called for by Iwanicki (1998). A third question was to determine if this process would be meaningful to them? At the end of the study, what will they choose to do? Lastly, would teachers become lovingly angry about the achievement gap experienced by their students, and change to better connect with them?

As the study began, teachers met as a group with the researcher. These teachers explored problems from many perspectives, generated alternative plans, and chose a plan for themselves Glickman (2002). The handbook provided options to help teachers engage in critical, abstract reflection. 
All study models were designed to improve teachers and student connections crucial to student learning in the classroom (Darling-Hammond, 1997; Nieto, 2002; Wood, 1998). They comprised a structure for teachers to explore their enduring, situated and endangered selves (Spindler \& Spindler, 1994). Teachers were motivated to consider their students' selves. Involving teachers to develop, interact with, and control the topics for study was central to the design. When teachers experienced agency, they committed to do the very hard work of defining and redefining their position, selves and teaching. Table 8 presents the timeline and content of study sessions as initially designed. The timeline was developed to follow the timeline used by the school district to evaluate teachers in our traditional as well as development for contract teacher models.

The first session was designed to explain all materials and processes of the study. Others sessions were learning sessions. Each learning session explored an issue of race, class, effective teaching in challenging situations, and identity. Time was allotted in each session for teachers to share their experience and to ask for feedback from others. Protocols were used during group sharing time to assure that all who want to participate in the conversation were included. Teachers completed exit forms, which gave them a chance to capture the highlights of learning sessions and to ask further questions they may not have been willing to share in the larger group setting. All teachers explored an aspect of their own teaching. 


\section{Table 8}

Field Test Timeline for the Teacher Self-Evaluation Handbook

\begin{tabular}{|c|c|}
\hline Assigned Topic and Reflection Questions & Purpose of Learning \\
\hline September 2009 & $\begin{array}{l}\text { Group Orientation Session } \\
\text { Conduct a self assessment } \\
\text { Set initial goals, and complete self survey } \\
\text { Receive materials } \\
\text { Select two options for self reflection }\end{array}$ \\
\hline $\begin{array}{l}\text { October, } 2009 \\
\text { Read Educational Leadership April } 2008 \text { Poverty } \\
\text { and Learning; and MLive.com Kuskegon Chronicle } \\
\text { "A third of public school students lives in poverty” } \\
\text { Question: How do we include all students? } \\
\text { Review Journal Entries }\end{array}$ & $\begin{array}{l}\text { Explore culturally responsive teaching } \\
\text { Receive feedback and help from teachers and } \\
\text { principal } \\
\text { Share updates on self study progress/questions } \\
1^{\text {st }} \text { set of feedback forms completed }\end{array}$ \\
\hline $\begin{array}{l}\text { November } 2009 \\
\text { Watch excerpts from Freedom Writers. } \\
\text { Question: How do your students’ realities have } \\
\text { space in your classroom? } \\
\text { Review journal entries }\end{array}$ & $\begin{array}{l}\text { What do teacher and students do in the film? } \\
\text { Explore culturally responsive teaching by } \\
\text { teacher in film } \\
\text { Share updates on self study progress/questions } \\
2^{\text {nd }} \text { set of feedback forms completed }\end{array}$ \\
\hline $\begin{array}{l}\text { December } 2009 \\
\text { View an interview with one student or family. } \\
\text { Share Mind’s Eye representations as a group. } \\
\text { Review journal entries }\end{array}$ & $\begin{array}{l}\text { Teachers will complete “T” chart to compare } \\
\text { and contrast their values and those they believe } \\
\text { their students hold. Work on a Mind's Eye } \\
\text { model as a group } \\
\text { Share updates on self study progress/questions } \\
3^{\text {rd }} \text { set of feedback forms completed }\end{array}$ \\
\hline $\begin{array}{l}\text { January } 2009 \\
\text { Read White Privilege - P. McIntosh } \\
\text { Take Ruby Payne surveys of survival in Poverty, } \\
\text { Middle Class, and Upper Class. } \\
\text { Question: } \\
\text { What are the hidden rules of your classroom and } \\
\text { how do you teach them to your students? }\end{array}$ & $\begin{array}{l}\text { Share reactions to White privilege, How can we } \\
\text { teach hidden rules in our middle class reality at } \\
\text { school to help students who do not have that } \\
\text { reality? } \\
\text { Share updates on self study progress/questions } \\
4^{\text {th }} \text { set of feedback forms completed }\end{array}$ \\
\hline Review findings and transcripts & $\begin{array}{l}\text { Spring term } 2010 \\
\text { Review findings and transcripts }\end{array}$ \\
\hline
\end{tabular}

One effective school improvement strategy in the literature is to make classroom walls more permeable (Peterson et al., 2002). To increase collegial connections, at least 
two teachers selected each self-study option. Each option was developed to increase the teacher's awareness of his or her interactions with students in the classroom. These options operationalized critical or democratic thinking. Options were designed to help teachers gain self-knowledge.

\section{Study Options}

Each teacher selected two transformative options. Additionally, each teacher or teacher team determined what impact their participation in their study options had on students in the classroom. Teachers developed study products, reflected with each other and journaled about their experiences. Teachers reported during their presentations that they believed student engagement increased as a result of the models teachers used to improve their teaching during this period of time. The following section describes each study option, including initially-proposed traditional models.

\section{Transformative Options}

Teachers chose one or two of these options.

The Iceberg Model. Adopted from the Systems Thinking and Dynamic Modeling Project (2002). There are conscious and subconscious ways of making observations. This model provides a structure to reflect on any area of teaching and learning; the goal is to reflect below the surface.

This approach departs from clinical supervision in that clinical supervision primarily relies on a surface-level observation conducted by the supervisor of the teacher. Ten percent of an iceberg is easily visible above the surface. If this percentage holds, merely observing a classroom yields a small percentage of understanding of what 
happens in the classroom. Below-the surface information guides our interactions with the world. If unexamined, we may limit our knowledge of our own interactions in the world. If teachers select this option, they may consider their beliefs about students or student beliefs about them. They may explicitly know their own beliefs. It is hoped that a breach in the connections between teacher and student will become evident to the teacher, and that the teacher may become motivated to explore their own teaching practices in new ways.

The Mind's Eye Model. Based on the work of Wink and Wink (2004), this model helps teachers reflect on their own beliefs, then learn about student beliefs to better understand both perspectives. The goal is to learn about disconnections or assumptions between the teacher and the student so that they can build closer connections in the classroom.

Similar to the Iceberg Model in its purpose, this option offers a different schema. If teachers fully develop a Mind's Eye Model describing their own beliefs and then work to develop an inclusive Mind's Eye Model from their student(s)' perspectives, then the teacher may understand interactions in the classroom in new ways.

Democratic school attributes in your teaching. This option gives a teacher a list of attributes developed by Apple and Beane (1995) that are called for in democratic classrooms. This list could be considered a lens to help teachers focus in a new way on their practice. Merely advising teachers to teach toward democracy is too broad a calling. This list can help teachers focus on various conditions and practices in their classrooms guided by this list. 
Spiral Model of Continuous Improvement. This schema helps a teacher select a practice, try it, reflect on the experience and outcomes, and then plan again. This particular representation comes from the work of Chenoweth and Everhart (2002).

If selecting this model, the teacher will use the model to characterize one or more aspects of his or her teaching during the self-evaluation process. This schema does not have a beginning and ending point. It is a way to visually represent reflection in practice. A teacher can select an aspect of his or her teaching, try a changed action, and determine the outcome. He or she will represent their work using this visual schema.

Student surveys. The surveys in this work come from Peterson (2000). Questionnaires or surveys are often used in university settings to gain feedback from students about their experiences in class.

The purpose of this survey is to make sure students understand classroom processes and to gather their perceptions. Teachers can use student feedback to improve class. In fact, teachers gather most of their feedback about efficacy of a lesson in their interactions with students. The classroom has been a protected and isolated space in many public school settings. It is rare that formal student feedback is included in teaching practices. Parent information can also be informative, but we have little to no parent feedback in public schools. A parent survey, also from Peterson (2000), is included for teacher consideration.

Community and home visits. Teachers will accompany others to conduct home visits. Teachers can then reflect about the interactions in the home and how they can apply this knowledge to connect more effectively with students. 
Teachers rarely live in the location of the school in which they teach. In our particular school, only two do live in the community. These teachers have been present through all the changes in the neighborhood. What was once a White upper middle class neighborhood with truck farms, suburbs, and drive ins has become filled with block upon block of dense apartments. As a transit line connected the inner city with this area, the transit line has brought crime, poverty, and diversity to a central core. I believe that if teachers can understand the environment in which students live, they may understand their students differently. At least, they may be able to make their instruction more relevant to their students.

Use the Structured Instruction Observation Protocol (SIOP). This is a framework for evaluating teaching. SIOP is a best-practice approach for teaching English as a Second Language, but may prove effective for children of poverty. Poverty research and English learning research cites the lack of academic vocabulary students have mastered as compared to native English or middle class learners. If SIOP is used in the classroom and if we gain feedback from teachers about how it works or does not work in a diverse, poverty environment, this experience may influence the individual teachers using this approach or the school improvement efforts in the school as a whole.

Educational history. This approach provides a schema to help teachers examine their own experiences in education. They may then reflect on their practices in their own classrooms - how the practices are similar to or different from the classrooms they experienced as students. Some teachers report that they are familiar with the schools of their youth, but are like fish out of water in a diverse public school setting. If student and 
teacher histories do not match up, a breach may become evident - an opportunity for teachers and students to understand and fill the breach.

\section{Traditional Options}

Participating teachers rejected all of these options. These are more traditional approaches often included in school district options for traditional clinical observation, or offered to contract teachers who engage in professional development/goal setting. They formed partnerships so that all transformative models were used by the participants in the study.

Classroom-based action research. This particular depiction applies the work of Chenoweth and Everhart (2002). The teacher will try a new approach to teaching classroom and capture the effect of that new approach in the classroom. The teacher will then reflect on outcomes and engage in another cycle. Action Based Research in this iteration is focused on the events within the classroom. If two teachers choose this option, they may both try one change and then can compare the outcomes. This can make the classroom walls permeable, called for by Peterson (2000).

School district standards and values. Each school district generally develops A teacher who uses this option will use the summative evaluation tools to characterize his or her own teaching. This framework is typically used only in a summative evaluation write up within the clinical evaluation process. Teachers have no voice or agency in capturing or characterizing their own teaching using this framework. If a teacher selects this option to self evaluate, he or she may focus on an area for improvement, which would otherwise never be selected by an outside observer. 
Videotaping classroom sessions. The teacher will videotape his or her lessons and then analyze the session for one or more aspects. Some suggested ideas are: reflecting on the level of questioning used, student collaboration, or inclusion of all students. This tool can be one that can illuminate a practice the teacher is using without being aware of that practice. Teachers usually have no way of viewing their own teaching. Although this is a traditionally used tool, teachers may use it to focus on connecting to students in new ways.

Before this experience, teachers had little input to their own evaluation processes and summative reports. I had anticipated that they would want to use the traditional approach for themselves, since they had not been empowered to that degree in the past. Surprisingly, all teachers rejected traditional models, and wanted to try the transformative approaches contained in the handbook.

\section{Culminating Research Session}

At the close of the study, teachers met in two culminating sessions to present their experience and products. Insights from their work during the study period emerged. They fully committed to learning more about themselves and their students. During this session

and after it, teachers revised the handbook, lesson plans and processes. All revisions were shared with study participants. All revisions and written summaries of their experience were accessible to and determined by them. Guiding questions for the culmination session were developed with the teachers, and related to the study questions initially developed at the onset of the study. Teachers addressed the following areas in their presentations: 
- How did this compare with former evaluation experiences?

- What are your results?

- Did you collaborate with others? Was it helpful?

- What obstacles did you encounter?

- Did this work change your interactions with students?

- Would you do this process again?

- Did the network of teachers in the group help build lateral capacity?

- How has your teaching changed during this time?

Every participant valued collaboration embedded in the study. Collaboration and dialogue led to interactive discussions and a deeper understanding of problems. Teachers developed rewarding answers to practical classroom challenges. They also determined that teaching is extremely complex, and developed more questions to explore in the future. The researcher recorded, by notes and audiotape, teacher observations to capture emergent trends or patterns.

\section{Main Product Revision: Steps and Description of Revisions Made}

Main product testing is beyond the scope of this study. A main field test occurs with a wider participation of teachers and or sites. It is meant to assure that the product being tested can be useful in other settings - that it is replicable. It is unclear at this time if the handbook will be used with other groups in the future. 


\section{Data Collection Procedures}

Teacher feedback was collected throughout the process. Initial surveys, exit forms and exit surveys were completed by the teachers and collected by the researcher. Teachers maintained a self-study journal that they shared. The researcher reviewed teacher journals with teachers' full consent. Electronic journals and blogs were also used by teachers and shared with the researcher. Teacher notes recorded discoveries teachers made about themselves, their students and each other during the study.

Teachers had access to State test data, teacher assessment tools, video and digital still camera equipment, student performance databases, as well as sound recording devices. Teachers collected student work samples during this time. Teachers summarized their learning experience and submitted a copy to the researcher. Teachers reported their own outcomes and discoveries they made because of their involvement in the study. Finally, the culminating group sessions and individual structured interviews also provided information in a celebrational and reflective mood.

\section{Data Analysis}

The researcher transcribed all interviews and sessions. This was a qualitative study with unanticipated outcomes. Cresswell (2005) wrote, "Data analysis requires that the researcher be comfortable with developing categories and making comparisons and contrasts. It also requires that the researcher be open to possibilities and see contrary or alternative explanations for the findings” (p. 153). The method of data analysis relied on reviewing artifacts gathered during this process. 
Teacher responses, journal entries, exit forms, and any teacher-developed artifacts were reviewed for common trends or common words. This study was a qualitative, problem-based-learning model study, and emerging trends and teacher feedback formed the body of work from which essential outcomes to the process emerged to inform future iterations of the handbook and processes involved.

Teachers had the opportunity to participate in a structured interview. Two teachers participated, and their interviews were transcribed and reviewed by them before they were analyzed for trends or patterns.

I was the researcher, the former principal of the school. As described by Peterson et al. (2002) my role was to be of service to the teachers, to involve teachers by giving them access to all data and reports and to carefully interact with all teachers in the study. These were some of my ethical obligations as researcher. All notes and writings were shared with participating teachers for their review and input.

Finally, teachers shaped the handbook and process. During all phases of the project, transcripts of interviews, presentations, or other artifacts were fully available for teacher review. As a qualitative study, findings and trends emerged.

\section{Ethics and Limitations}

This study was a contextualized, socially situated study. Using a problem-based learning model, this doctoral study explored a problem in practice. I was the researcher; I was a resource to teachers and was an inside observer. The participating teachers were high performers. They are contract teachers with the option to set multiple year goals as part of their professional development activities. They also have experienced consistently 
favorable reviews in the past. Participating high performers were also teachers who have led school improvement efforts by serving on a Leadership Team, Site Council, or other focused, school-side effort. It is predicted that these teachers will continue receiving favorable reviews in the future.

Although these teachers are most likely to continue to receive extremely laudatory evaluations, to safeguard the teachers from any biases or negative evaluation experiences, an assistant principal or the new school principal at the close of the study period may have evaluated them on the summative evaluation forms. I did not directly evaluate any of the teachers participating in this study.

The researcher role I took in this study is defined by Bridges and Hallinger (1995), who explained, "The researcher will gather formative and summative evaluation data about how the project can be improved and its efficacy” (p. 127). I introduced the study to participants, gathered their initial surveys, worked with teachers during the study sessions, and facilitated the culminating group session. Teachers remained in charge of what and how information was shared.

Asking teachers to review and correct transcriptions of sessions and incorporating teacher feedback were essential safeguards. I shared trends that seemed to emerge in the study with participants. These teachers were working at the refinement level of teaching practice. Teachers were not engaged in a peer review that could lead to negative outcomes as cautioned against by Peterson (2000). The risk to teachers in this selfevaluation process was limited by virtue of them determining their own evaluation and by the teachers reporting to a person other than the researcher. 
Ethical considerations arise from complex situations in which there are competing claims for personal rights and moral values, priorities and consequences (Peterson et al., 2002). This study posed little to no risk to teachers in the evaluation process. Each teacher was self-evaluating. Teachers were not called upon to evaluate any aspect of other teachers' practices.

At the onset of the study, the group agreed on principles of confidentiality, assuming good intent, and other values. These are listed as core beliefs and are included in the handbook. Core beliefs to honored during the pilot study were:

- Excellent public education is our goal

- Trust and confidentiality are essential

- Democracy is impossible without a literate populace

- All students deserve a beautiful education

- Love is central to all education

- Teachers are committed professionals

- Teachers reflect and think of problems from different perspectives

- All students can learn

- Optimism - teachers strive for what can be

- The commitment and abilities of teachers predict student ability

- Passion and fun are essential elements

- High performing teachers are open to change

By reviewing and interpreting this list, the group was able to adopt norms for their work. There was no instance of anyone breaking the norms. 
Rights and privacy of teachers were safeguarded. The following core beliefs were upheld for added trust, safety and dialogic interactions:

- Meet the obligations of time, effort, insight and learning

- Treat information, data and procedures as confidential, unless required by law

- Use information, data and procedures for their intended purposes

- Carefully control personal notes and records

- Engage in the activities of the study independent of considerations of race, color, creed, sex, national origin, marital status, sexual orientation, political or religious beliefs

- Analyze, disclose, and resolve conflicts of interest

- Participate in evaluation of their own evaluation activity

Being explicit about expectations and commitments safeguarded all participants in this study. Everyone listened to understand, and relished in the discoveries of other teachers.

\section{Description of PBL: Possible Outcomes and Next Steps}

This study was a field test of a self-evaluation process for high performing teachers. The focus of the process was to operationalize transformative teacher evaluation. Teachers were involved in all aspects of the study. Questions emerged from the teachers' work. Teachers focused on closing the achievement gap and fostering democracy in the classroom. Teacher trust appeared not to limit their full disclosure. Teachers were hard on themselves, but consistently mentioned being optimistic. 
This field test of the handbook could lead to another application of the handbook in a new environment in the future, or to its revision. I hope that this experience of the teachers using the handbook will contribute to the field as an application of transformative evaluation practice. These experiences can build a new body of knowledge that can capture experiences, data, social challenges, recommendations and discoveries of the teachers to inform future work.

Teachers gave space to student diversity, including cultural difference, language difference, poverty, and special-needs students. They engaged in the off limits reflection Howard (1999) suggested, "to encourage White educators to look deeply into the nature of dominance, to understand the... tragic impact it has in the lives of our colleagues and students” (p. 68). Teacher reflection and exploration went beyond observable traits to intangible values. They committed to their students and each other in new ways.

\section{Description of the PBL: Self Evaluation Handbook}

The draft handbook appears after the references of this paper. Initial field-testing is now complete. The logical next step in the handbook's development is to test it with another school's team. This handbook helped connect teacher evaluation to whole school improvement, called for by Iwanicki (1998). Study replication would require a collaborative principal and teacher leaders who embrace innovation to improve school.

\section{Chapter Summary}

The problem based learning research included 10 high performing teachers. They piloted a new handbook to self assess, engage in learning sessions, set goals, and implement changes in their classrooms. Teachers attended and conducted demonstrations 
of their products and learning in a culminating event. Teachers were integral in all drafts and revisions of the handbook; participants reviewed findings for accuracy. They also reviewed this dissertation paper for accuracy, especially when teachers were quoted. Teachers not only wished to continue studying together, but they also wanted to include more teachers in this experience. The activities and outcomes in this project proved relevant to teachers. They reported that this study helped them connect with their students and, consequently, that their students showed a greater level of engagement in learning.

This work and the future improvement of teacher evaluation are essential and urgent for teachers and students. I hope that teacher self-evaluation for high performing teachers can become a valued tool for educators to use as they work to improve education for all students. As one element of our practice in public schools, it must hold promise to improve school for students. 


\section{CHAPTER IV}

\section{THE PROBLEM BASED LEARNING PILOT STUDY}

\section{Pilot Handbook Study Overview and Process}

This research project was the preliminary field test of the Self-Evaluation for High Performing Teachers Handbook. The handbook contains models for teachers to consider in reflecting on their own teaching. The models for study encourage teachers to consider below-the-surface beliefs of themselves and their students. Teachers in the study had served in leadership roles during years preceding the study, and had considered the Iceberg and Spiral Models in professional learning community sessions. All teachers held contracts; they were beyond probationary status. They also were familiar with traditional evaluation models, having experienced clinical evaluation in the past.

In June 2009, I was principal of Lincoln Middle School; I was also the researcher of this study. My leadership style is collaborative, and I believe that the most important interaction in any school happens between the teacher and the student in the classroom. I also believe that teachers are generally highly committed to students and that they desire to improve. In my work with teachers, my role is to serve and support them (Peterson et al., 2002). The pilot handbook and models emerged from my experiences first as a teacher and later as a principal. My own dissatisfaction with teacher evaluation motivated my work to develop study options that would possibly be meaningful to teachers and 
improve their teaching. As a result of using these study options, I hoped that teachers would see improvement in their practice.

After receiving approval for the study, teachers were recruited based on their status as contract teachers with consistently exemplary evaluation reports over time. After identifying all the teachers meeting the first two criteria, consideration was given to their subject area, leadership activities in the building, age and gender. All teachers were assumed to be White and of middle class. Fifteen teachers met with me individually to explore what it would mean to be a part of the study. They were given the pilot handbook, and asked questions about the study. Eleven teachers committed to the pilot study, and signed Informed Consent Forms. A teacher I am not counting as a participant attended October session, and did not complete any of the project activities. Teachers agreed to have their names used and complete tasks required by the study. They were assured that they would frame the experience and review all written materials included in the study. Later, to protect their identity, all teacher names, school and district names were changed to pseudonyms. Teachers were notified of this change.

It was propitious timing that teachers were identified, as multiple leadership changes occurred before and during the study. With each change in leadership, the continuance of the study could have been jeopardized. In August 2009, my assignment was changed from building principal to the English Language Development Coordinator for Wool School District. The superintendent approved the fall study, simultaneously offering me the new position. I met with the incoming principal of Lincoln Middle School, to make sure he knew about the study and the participating Lincoln teachers. The 
principal and his secretary appeared thankful to exclude study participants from the formal evaluation process. Some participating teachers were disappointed, as they perceived lost observations as lost feedback opportunities.

Another change happened when a new Human Resources Director joined the Wool School District. I met with him and the new Superintendent. Once again, focus on the high performing teachers posed little concern to the overall system. Given that this study compliments the current choice contract teachers have to study their own teaching as an evaluation option, this study proceeded with full support.

In December 2009, the superintendent resigned. Consequently, the Director of Curriculum and Instruction became acting superintendent. She was fully informed about this study, including reviewing the handbook. She urged the study's completion. In December 2009, I became Director of Federal Programs. Since the study was underway, it continued without concern. All the Wool School District leaders were invited to visit study sessions; the Lincoln Middle School principal briefly attended one session.

The significance of these changes is that my role in relationship to the teachers changed. The environment of the district as a whole continued to change, causing stress and uncertainty for the teachers. The district also experienced a reduction in force of more than a hundred teachers which took effect the September of the study. In the midst of these changes, high performing teachers stepped up to improve their teaching and make the classroom environment predictable for their students. 


\section{Pilot Study High Performing Teacher Participants}

- Jerry Guy, eighth grade Science Teacher (brother of Sid). Sid and Jerry often teach together, as a curtain separates their rooms. Jerry is more spontaneous than Sid.

- Sid Nye, eighth grade Science Teacher (brother of Jerry). Sid is older than Jerry, and meticulously plans lessons. Both teachers enjoy their work and each other.

- Matthew Bill, Elective Science and Robotics Teacher. Matt is an outdoorsman, and loves bringing science to students who have little science experience.

- Martha Bauridel, Literacy Coach. Martha enjoys data analysis, tracking student progress and sharing data with others. She is a resource to all teachers in the building, and is sought out by them to help them in lesson planning and delivery.

- Lilly Strong, Social Studies. Lilly is quiet, self sufficient, and reflective. She creates a classroom climate of openness. Lilly was a loner prior to this study.

- Marie Montag, Reading Teacher. Marie loves her reading bubble, and teaches students to read using technology (Read 180), modeling a love of literature.

- Marion Reliant, Media Specialist. The library is the living room of the school, and Marion is the host. He is a book pusher and tracks circulation rates. Marion knows the collection and students. He continuously seeks out student-requested titles.

- Ona Clark, Special Education Specialist. Ona is a child advocate, acting on behalf of special education students. She co-teaches with mainstream teachers. 
- Dora Adventurous, English Language Development Teacher. Dora welcomes every newcomer and ELL, working tirelessly to help students gain English as soon as possible so that they can express their feelings and learn.

- Lillian Umbaugh, Mathematics Teacher. Lillian is a math fanatic. She knows that modeling a love of math for students, especially girls, is key to their futures.

All teachers signed Informed Consent Forms approved by Human Subjects agreeing to use their actual names in the work. However, to protect the teachers' identities and for additional privacy for them in their professional and personal lives, pseudonyms are used throughout the dissertation. Pseudonyms are also used for the school and district names.

Whereas teachers seem homogenous White and middle class, they reported complex identities not initially evident. Teachers were asked to describe their age, gender or other identity and how long they had been teaching. Some teachers had difficulty deciding what to reveal or what identity or other meant. Teachers defined themselves in their own way. The responses help to round out the brief description of participating teachers.

Table 9 organizes teacher responses from the entry survey. Naming identity only begins to mirror the complexity within the many students they work with on a daily basis. One participant reported multiracial, but had never shared that identity with other teachers in the school. Others explicitly shared their religion. Teachers had minimally shared their identities or personal experiences with others at school before completing the study. 
Table 9

Teacher Identity

\begin{tabular}{|c|c|c|c|c|}
\hline Age & Gender & Identity & Other & Name \\
\hline 39 & $\mathrm{~F}$ & Oregonian & Raised in Indonesia & Dora Adventurous \\
\hline 28 & $\mathrm{~F}$ & White & Single & Ona Clark \\
\hline 43 & $\mathrm{~F}$ & White & $\begin{array}{l}\text { Married } \\
\text { Middle Class } \\
\text { Poverty Experience }\end{array}$ & Lillian Umbaugh \\
\hline 45 & M & Catholic & Ministry & Sid Nye \\
\hline 34 & $\mathrm{~F}$ & Atheist & & Martha Bauridel \\
\hline 34 & $\mathrm{~F}$ & Multiracial & $\begin{array}{l}\text { Wife, daughter sister } \\
\text { friend }\end{array}$ & Lilly Strong \\
\hline 40 & M & Caucasian & $\begin{array}{l}\text { Right handed } \\
\text { Lazy eye }\end{array}$ & Jerry Guy \\
\hline 33 & M & & $\begin{array}{l}\text { Relaxed } \\
\text { Adrenaline junkie } \\
\text { People should own their } \\
\text { choices right or wrong }\end{array}$ & Matthew Bill \\
\hline 56 & $\mathrm{~F}$ & Jewish & Passionate for reading & Marie Montag \\
\hline 49 & M & White & $\begin{array}{l}\text { Married, protestant, middle } \\
\text { class, English only }\end{array}$ & Marion Reliant \\
\hline $28-56$ & $\begin{array}{l}4 \text { male } \\
6 \text { female }\end{array}$ & $\begin{array}{l}9 \text { White } \\
1 \text { multiracial }\end{array}$ & $\begin{array}{l}\text { Religion, Race } \\
\text { Class, Familial role }\end{array}$ & \\
\hline
\end{tabular}

Participant teaching experience ranged from 4 to 30 years. The average number of teaching years of the group was 12. The cumulative years of experience was 116 years. Most teachers had some years teaching in another setting, with the longest-tenured teachers teaching at the same school for 6 to 16 years.

\section{Study Sessions}

Study sessions were held in the Lincoln Library. Study sessions developed by the group are presented in Table 10. 
Table 10

Pilot Study Lesson Topics and Session Experiences

\begin{tabular}{|c|c|c|c|c|}
\hline Date & Topic & Materials & $\begin{array}{l}\text { Session } \\
\text { Experiences }\end{array}$ & $\begin{array}{l}\text { Future } \\
\text { Expectations }\end{array}$ \\
\hline $\begin{array}{l}\text { September 16, } \\
2009 \\
\text { All present }\end{array}$ & $\begin{array}{l}\text { Orientation } \\
\text { Identify and pair } \\
\text { up for study } \\
\text { models }\end{array}$ & $\begin{array}{l}\text { Entry Survey } \\
\text { Quick Write } \\
\text { Lesson Plan } \\
\text { Calendar } \\
\text { Handbook }\end{array}$ & $\begin{array}{l}\text { A guest speaker - } \\
\text { learn about } \\
\text { African American } \\
\text { experience }\end{array}$ & $\begin{array}{l}\text { Group asked for } \\
\text { guest speakers } \\
\text { Desire to share } \\
\text { student work }\end{array}$ \\
\hline $\begin{array}{l}\text { October 21, } 2009 \\
\text { Two absent }\end{array}$ & $\begin{array}{l}\text { African } \\
\text { American Guest } \\
\text { Speaker } \\
\text { And After } \\
\text { School Class } \\
\text { Facilitator: } \\
\text { Boys Reflecting } \\
\text { Brotherhood } \\
\text { Miles Strong }\end{array}$ & $\begin{array}{l}\text { Macintosh } \\
\text { Privilege Survey } \\
\text { Oregonian: the } \\
\text { Gates Incident } \\
\text { Racist Cartoons } \\
\text { Miles's and } \\
\text { Students' art }\end{array}$ & $\begin{array}{l}\text { Miles shared his } \\
\text { childhood and } \\
\text { school experience, } \\
\text { work with AA } \\
\text { students, and } \\
\text { offered himself as } \\
\text { a resource to } \\
\text { teachers }\end{array}$ & $\begin{array}{l}\text { Teachers } \\
\text { understand AA } \\
\text { male student } \\
\text { reactions } \\
\text { Teachers asked } \\
\text { for study method } \\
\text { information }\end{array}$ \\
\hline $\begin{array}{l}\text { November18, } 2009 \\
\text { Three absent }\end{array}$ & $\begin{array}{l}\text { Resilience } \\
\text { Race and Class } \\
\text { Student } \\
\text { Engagement }\end{array}$ & $\begin{array}{l}\text { Art Materials } \\
\text { Oregonian } \\
\text { articles: Survival, } \\
\text { immigrants, } \\
\text { radicalized } \\
\text { violence }\end{array}$ & $\begin{array}{l}\text { Think pair share } \\
\text { protocol used. } \\
\text { Teachers } \\
\text { discussed how } \\
\text { materials } \\
\text { informed their } \\
\text { teaching }\end{array}$ & $\begin{array}{l}\text { Articles were } \\
\text { haunting } \\
\text { Teachers want to } \\
\text { see each other's } \\
\text { classes Teachers } \\
\text { want to learn how } \\
\text { to teach resilience }\end{array}$ \\
\hline $\begin{array}{l}\text { December 16, } \\
2009 \\
\text { Three absent }\end{array}$ & $\begin{array}{l}\text { Personal } \\
\text { qualities and } \\
\text { positive } \\
\text { attributes }\end{array}$ & $\begin{array}{l}\text { Children learn } \\
\text { what they live } \\
\text { Nolte } 1972 \\
\text { Resilience } \\
\text { materials } \\
\text { Payne materials }\end{array}$ & $\begin{array}{l}\text { Teacher brought } \\
40 \text { assets article } \\
\text { And What makes } \\
\text { Us Happy article }\end{array}$ & $\begin{array}{l}\text { Teacher said } \\
\text { SIOP is his friend } \\
\text { What can teachers } \\
\text { do to improve } \\
\text { resilience? }\end{array}$ \\
\hline Date & Topic & Materials & $\begin{array}{l}\text { Session } \\
\text { Experiences }\end{array}$ & $\begin{array}{l}\text { Future } \\
\text { Expectations }\end{array}$ \\
\hline $\begin{array}{l}\text { January 20, } 2010 \\
1 \text { teacher absent }\end{array}$ & $\begin{array}{l}\text { Leadership and } \\
\text { Resilience }\end{array}$ & $\begin{array}{l}\text { Cox Dissertation } \\
\text { Surveys } \\
\text { Actions to foster } \\
\text { resilience }\end{array}$ & $\begin{array}{l}\text { Teachers } \\
\text { discussed what } \\
\text { they are doing } \\
\text { aligned to the } \\
\text { study information }\end{array}$ & $\begin{array}{l}\text { More time was } \\
\text { spent in this } \\
\text { session on study } \\
\text { models than } \\
\text { before }\end{array}$ \\
\hline $\begin{array}{l}\text { February 10, } 2010 \\
\text { Changed due to } \\
\text { Ash Wednesday } \\
1 \text { absent }\end{array}$ & $\begin{array}{l}\text { Presentation of } \\
\text { Projects }\end{array}$ & $\begin{array}{l}\text { Six study pairs } \\
\text { presented }\end{array}$ & $\begin{array}{l}\text { Voices were } \\
\text { recorded }\end{array}$ & $\begin{array}{l}\text { Homework: exit } \\
\text { survey, goal } \\
\text { setting, completec } \\
\text { projects }\end{array}$ \\
\hline $\begin{array}{l}\text { February Make Up } \\
\text { Session } \\
6 \text { present }\end{array}$ & $\begin{array}{l}\text { Presentation of } \\
\text { Projects }\end{array}$ & $\begin{array}{l}\text { Four additional } \\
\text { study pairs } \\
\text { presented }\end{array}$ & $\begin{array}{l}\text { Voices were } \\
\text { recorded }\end{array}$ & $\begin{array}{l}\text { Teachers wanted } \\
\text { additional } \\
\text { sessions }\end{array}$ \\
\hline March & Interviews & Exit Surveys & & \\
\hline
\end{tabular}


Teachers checked in during dinner, and engaged with study materials. Sharing and reflection increased as the study progressed. Study partners worked independently and collaboratively between sessions. While there was intense focus during each session, subsequent sessions became longer, due to conversations that emerged. After each session, participants lingered. September and October lessons followed the initial study plan, while participants shaped others. Teachers took the Unpacking the White Knapsack (Macintosh, 1988) work and the Guest speaker's presentation to heart in the October session. Two participants had a religious holiday conflict in February; the group changed the date to accommodate them. Those who missed sessions caught up with their partners.

Teachers began to share their worries, identities and desires to connect with and truly change the lives of their students - to know and love all students. Teachers honed in on resilience as a focus area. All teachers used their study models to connect with their students, and to strive to help students thrive.

As the study came to a close, all teachers requested additional study time, and most wanted to continue the roundtable format. All 10 teachers who began the study completed it. One additional culmination session was held to accommodate all the teams to present their projects. Follow up for interviews, goal setting and exit surveys was necessary to accommodate all participant presentations. Not every participant completed the final pieces of the goal setting or the exit survey activities. 


\section{Highlights of Individual Sessions}

\section{September Session: Orientation, Study Model Selection, Entry Survey}

The first session was somewhat awkward. Some teachers work with each other, while others had not interacted much due to their location in the building and their various curricular areas of responsibility. Eating dinner together, chatting and touching base with each other made the teachers relax and recharge. There was a tense air, with teachers curious about what they would need to do to complete their part in the study.

During this session, teachers reviewed the handbook as a group. Their clarifying questions were similar to those of any student - they wanted to know what they needed to do to succeed. The questions about the study model focused on specificity. When they learned that the models were new, exploratory and that they could develop any product or process they wished guided by the model, teachers remained curious.

When time to select study models, the group decided to reject all the traditional options. In fact, this decision led to the deletion of traditional models from the handbook. Participating teachers divided the group so that two to three teachers selected each transformative model. They checked in with each other and traded models until everyone committed to two models.

\section{Study methods selected by teachers.}

Educational History Model - Lillian Umbaugh, Marie Montag, Ona Clark. This model calls for teachers to explore their own educational histories with each other. Then, they reflect on the educational realities and histories of their students. The object is to discover each other and the realities experienced by their students. 
Iceberg Model - Lillian Umbaugh and Ona Clark. The Iceberg Model presents the Iceberg as a tool to delve beyond the surface level of observing events to discovering patterns and deeply held beliefs. At the deepest levels of reflection, deeply held beliefs and how they influence our interaction with the world are considered. Events can be superficial, but decisions regarding the events are often guided by deeply held beliefs.

Spiral Model of Continuous Improvement - Dora Adventurous, Martha Bauridel. The Spiral Model guides the reflective practitioner to chart a course, reflect, take stock and chart a new course. This continuous reflection presents a look back and a forward charting of work that teachers often do; this model guides the reflection and planning. By taking time to reflect with a structure, aspects of work or improvement can become more explicit.

Student Surveys - Sid Nye and Jerry Guy. Surveys are used to take stock and gather information. The surveys suggested in this model are designed to learn more about student and parent realities. With an increased awareness of student realities, teachers can find ways to connect with students or discover areas they need to improve in their work with their students in the classroom, in the halls, and in the community.

Community Visits - Lilly Strong, Marion Reliant and Marie Montag. Community Visits provide teachers who comfortably care for students in school the opportunity to interact with students in the student's home environment. Suggested visits include a place of worship, student homes, the catchment area of the school, or other places students and families go. If teacher reality is middle to upper class, while their students live in 
conditions of poverty, visiting student homes and the community can provide a wealth of increased awareness for teachers when trying to connect and teach their students. Democratic Attributes - Matthew Bill, Marion Reliant. If public education is necessary for a democracy, then contemplating and implementing democratic attributes in the classroom can act as a training ground for inclusive, responsible and informed interactions in the community. Additionally, if teachers are viewed as the orchestrator of learning and the students are mere recipients; the interaction of students with learning can be receptive, not empowered. This model provides little guiding structure, but defines a philosophical base.

SIOP Model - Matthew Bill and Jerry Guy. The Structured Instruction Observation Protocol model is used to assure that teaching is planned and implemented to be effective for ELL students. Designed to increase academic English skills, it benefits ELL students as well as students who lack academic vocabulary. This model guides lesson planning so that the teacher can assure that explicit vocabulary instruction, language structures, student engagement, group work and pacing are included.

Mind's Eye Model - Sid Nye and Dora Adventurous. The Mind's Eye presents many experiential and cultural realities that act as lenses. Aspects such as age, gender, religion and others influence how individuals interact with the world. This model helps the reflective practitioners to make their own identities explicit. It can also help teachers learn how they share some values or beliefs with students as well as areas in which their ideas are in dissonance with student realities. 
One of the elements of the study design was that each model would have to be selected by at least two teachers for it to be used. This built in collaboration beyond the study sessions. To select their models, teachers asked each other about their most-wanted model. The made sure among themselves that each teacher had at least one of their mostdesired study models. Teachers exchanged their second or third choices until all transformative models were selected by at least two teachers so they would be explored during this pilot study. They rejected the traditional models, opting to explore new ideas. Another interesting negotiation of the group was that they worked with one person familiar to them and at least one teacher relatively non connected to them in their past work.

At the end of this session, participants completed their initial survey on computers located in the library. Estimated time for the entry survey completion was 45 minutes, but participants spent up to two hours. Some took several days to reflect. Teachers talked with each other to clarify the meaning of questions. They shared that they had never been asked in depth questions about their teaching practice. Their deep and focused engagement was astonishing. This survey captured the teachers' hopes, ideas, identities and concerns. Some survey questions elicited detailed responses, while others did not.

The entry survey: Identities and hopes of participating teachers. The survey questions were selected to help teachers focus on teacher evaluation, professional development, connecting with their students and goals or hopes for the future. All teachers completed this survey, with many collaborating to do so. They sat side by side at computers in the Lincoln Middle School library. 
- How do teachers feel about teacher evaluation? Do they find it meaningful?

What do they expect from teacher evaluation?

Teachers valued collaboration with others more than teacher evaluation, one wrote:

I expect teacher evaluation to be honest, helpful, relevant and actionable. An administrator evaluated me in two minutes - he called it a "snapshot" and I found it offensive. He told me to change my bulletin boards! As educators we spend so much time alone in our classrooms that we can start to develop tunnel vision in regards to our routine and practices.

Marie Montag's statement captured another view when she wrote,

I feel that teacher evaluation has been a chore rather than a tool to help me improve my teaching. Occasionally, I have had an evaluator who has made my evaluation meaningful and an opportunity to improve. I have always wished that it were a dialogue about strengths and areas of improvement for future exploration.

Even though Marie is now a reading teacher, she was an administrator in the past. She also shared that when an evaluator is perceptive and collaborative, the experience of receiving feedback can be reinvigorating.

Table 11 depicts an analysis of words used in teacher responses when describing their teacher evaluation experiences.

Contract teacher evaluations are generally fully positive. It is interesting that in the word analysis teachers overwhelmingly reported negative feelings toward the teacher evaluation experience. Their responses mirror trends in the supervision evaluation literature, when they report that it is perfunctory, ritualistic and tedious (Peterson, 2000). Jerry Guy, a long-term teacher, shared his apathy and his hopes for the future:

I have been a teacher in this school district for over 16 years. During that time, I have developed a sort of apathy toward the district's evaluation system. I have been observed by at least 10 administrators. I can safely say that every formal evaluation I have had has done little to improve my overall performance in the classroom. From the snapshot observation administrators make of my teaching I do receive helpful critiques regarding the specific lessons I am teaching. 
However, I am looking for assistance in improving my philosophy and overall approach to education. This is a bit more daunting task that requires a bigger commitment than two observations a year. This is a commitment that I feel I should be responsible for and not rely on sporadic visits.

\section{Table 11}

Word Analysis of Initial Teacher Evaluation Response

\begin{tabular}{|l|l|l|}
\hline Negative & Neutral & Positive \\
\hline Nervous & Just a rating & Help teacher improve \\
\hline Disappointing & Just get it done & Makes focus possible \\
\hline No areas for improvement & Pleasant chat & Meaningful \\
\hline Focus on the negative & A chore & Opportunity to improve \\
\hline Clumsy & Agree with it & Outside eyes reflection \\
\hline Tedious task & Necessary & \\
\hline Get it out of the way & Apathetic & \\
\hline Not important & & \\
\hline Euphemizing flaws & & \\
\hline Tell the evaluator what they want to hear & & \\
\hline Offensive & & \\
\hline Insufficient & & \\
\hline Push through it & & \\
\hline
\end{tabular}

Another teacher hopes, "I want to be a lean, mean, teaching machine, and sometimes it takes outside eyes and self reflection to make those changes.” Later, likening evaluation to a doctor visit, Jerry Guy wrote, "It is like going to the doctor and telling her that you feel fine so that she won't have any reason to find anything wrong with you.”

- What benefits do you expect from participating in this process?

Teachers desired insight, knowledge and reflection with others. They welcomed a framework to guide their reflection. Some were unsure of what they expected, while 
others chose linear models that provided more structure. An example of the high commitment was shared by Marion Reliant, “...To deepen our mutual understanding of how we impact the lives of the young people we serve.”

Sid Nye revealed commitment, worry and hope:

I expect deep reflections and examination of my attitudes, my practices and myself. I expect to find tiny demons that I did not know existed... I expect part of this process to be uncomfortable and even painful at times. I also expect to come out refreshed, renewed, reinvigorated and able to handle even bigger challenges.

At this juncture, teacher responses showed hope as well as an underdefined expectation. I believe this trend was due to the structure of the study. The structure was loose enough to allow teachers to develop emergent knowledge. This lack of specificity is necessary for a problem based learning model design to be effective.

- Describe recent professional development you found meaningful. How would you like to develop as a teacher?

Teachers identified high quality professional development that provided them with collaboration, information and practical application. In fact, teachers were eager to share their classrooms and practices with others. None of the professional development experiences they described were curricular in nature. Their development goals were neither curricular nor aligned to the teacher evaluation rating areas rudimentary or beginning elements of teaching often rated in teacher evaluation processes. Sid Nye reflected back to conferences and training sessions the Leadership Team had experienced in the past. He wrote about me when he claimed, "The love and passion of the principal and her support has sustained my enthusiasm for teaching.” Professional Development valued by teachers included: 
- Learning to create blogs and Wikis on the computer is helpful and practical

- Teacher led professional development day

- Oregon Superintendent Summer Conference

- Model Schools Conference

- Reading Association Leadership Conference

- Sheltering Workshop Structured Instruction Observation Protocol (SIOP)

- Co-teaching with brother: daily collaboration, from data to frustrations, focus

- A speaker from Russian Oregon Social Services - helped teacher understand Russian students and identify more with her own Ukrainian cousins

- Positive Behavior Supports (PBS) training

- Professional Learning Communities (PLC)

Teacher goals included:

- Address multiple student concerns during a class period

- Know the students on a cultural level

- To build a relationship with families and students

- To be a better resource to others

- To become forceful, decisive and brave

- To reach a wider range of students and inspire them

- Better ways to teach students how to become independent learners.

All teacher goals aligned with democratic attributes. Every teacher hoped to make a change and to see positive outcomes for their students. These goals were emotive, not based on measurable outcomes, like test scores or attendance rates. 
- How do your cultural values compare and contrast with student values?

Most teachers believed that their own cultures and values have become more disparate from student cultures and values. They were aware of a change in student population. They reported more differences than similarities. They felt like they were in unfamiliar territory when they interacted with their students.

Marion Reliant characterized the shifting reality he has seen in his career:

The district has gone through a big change in student demographics from a primarily White middle school student body to a low-income ethnically rich community. As a result, I have found myself in a position feeling like a new teacher to education. Old approaches that used to work are no guaranty as to be effective to today's population.

Teacher responses showed two broad themes: a focus on connection of any kind or a description of difference and disconnection. More teachers cited differences between their students and their own experiences than similarities. Table 12 organizes the two trends from teacher responses.

The general themes in the area of connection or commonality with their students included family values and temporary poverty. Only one response truly celebrated diversity, and included love or diversity, cultural difference and values.

- How do you create enthusiasm in your classroom and in the building? How can you optimize learning for each student?

Teachers did not report specific strategies to create enthusiasm. They sought rigor, relevance, and relationship mirroring the model of Daggett (2008) that several teachers learned about during the Model Schools Conference one summer earlier. Some teachers sought to build a respectful learning community in the classroom. 


\section{Table 12}

\section{Teacher-Student Connection and Disconnection}

\section{Differences and Disconnection:}

- My cultural values clash pretty hard with those of my students. However, I would be naïve to say I understand all the cultural values of my students.

- I desire a personal connection... but many roadblocks exist for us.

- Most of the students are Christian and I am an atheist.

- I believe in the WASP-y traditions of thrift and hard work, whereas, many of our students come from a live for today type background.

- I grew up in an intact nuclear family that ate dinner together every evening. Many students hardly see their working parents or spend quality time together. Regardless of cultural background, all students look for stability in their life. I am looking for community building in my classroom that requires all points of view to be understood and appreciated.

- A lot of their families have immigrated to this country for better opportunities

- High achievement is a new value for my students

- My background matches only a small percentage of my students.

- I am a middle-class, middle-aged Protestant White academic. I speak English only. I do not play video games, participate in organized sports, or watch television. I desire a personal connection with each student, but many roadblocks exist for us.

- I grew up in a small rural poor town. Although I come from a diverse family, my town was not diverse.

- I know what it feels like to come from more than one country. However, I 'm not aware of all the similarities and differences in our cultural values.

- My values are faith, family, respect, education, professionalism, play, creativity, character and community. I think most people value these things at some level.

Connection:

- Many of the values of family and love are the same.

- My students and I share strong family values, I grew up with a large extended family... many of my friends never even knew their cousins.

- Growing up multiracial gave me an early cultural awareness that my students appreciate

- I love the diversity of my students and enjoy cultural differences and values.

- Growing up poor in East Multnomah County and then later moving to a wealthier neighborhood in high school helps me see where students are. Knowing that springboard helps me assist student along their learning path. 
While I had anticipated that teachers would have multiple strategies they had developed over time, teachers seemed not to have many tools to use to create enthusiastic, safe, engaged learning environments. Teachers did not directly voice negativity; all teachers want to help and connect with students. In fact, most teachers shared one sentence related to engaging and modeling a love of learning. Some teachers seemed to not know or even to be discouraged. One teacher quipped, “Wouldn’t it be nice to push the 'optimize' button?”

- What are your passions and hobbies? How do you feel when you engage in them? How can personal passions come in to your teaching?

All teachers linked their hobbies and passions to their teaching. For Martha Bauridel, her teaching is her passion, "My main passion is teaching. I feel that encouraging students to reach their highest potential is incredible! Making a difference in a student's life is the highest honor." Sid Nye recalled a passionate flow, "When I am engaged in my passions I feel like I don’t need to eat, sleep or drink. I can’t keep my personal passions out of my teaching. You are your passions. If you are yourself in the classroom, then your passions will pervade everything you do.” In another example, Matthew Bill connected his passions, hobbies, and teaching to a larger context:

Travel, snowboarding, climbing, learning, hiking, biking and camping. These are my favorite things and probably the reason that I am a science teacher. When I participate in these activities, my mind is constantly moving through the science behind them and it simply amazed me to think of the potential our bodies and our planet have.

This question was answered consistently and all teachers found ways to connect their passions to their work. Perhaps this is the one value they shared in common more than 
any other. Teaching for these high performing teachers is an avenue for them to explore and activate their passions - their love of learning.

- Have you experienced exclusion such as racism or ablism? Have your students? Matthew Bill shared the strongest statement reported by the group. He asserted, "I believe that no one has led a life free of racism in one form or another, even if they are unaware that it occurred.”

Most teachers did not report marginalization in their own experience, but were aware of challenges their students face on a daily basis. Although all teachers appeared White in the group, our multiracial participant, other-than-Christian participants and teacher who grew up in Indonesia, held complex views and deep awareness of marginalization. Women and men reported gender bias. Teachers felt convinced that students do not know them, make assumptions, and predict that the teacher will be unfair to them. Jerry Guy said that he works for trust, believing that if he does not gain it, the students “won’t learn a thing from me.” Other teachers did report an experience or time that helped them understand what students face.

Ona Clark shared her college experience,

When I was in college, I moved into a neighborhood with sophomore-approved housing. Most nights people would drive by my place and scream, "Get out White (insert curse words)." Neighbors helped me and started reporting to the police the license plates of those doing this. I told my story in class, and the professor said that they had every right to say those things to me. He said that when White people move into an area, the rent goes up and they were protecting their homes. 


\section{Overall Observations from Entry Survey}

Participants earnestly answered all questions, and requested additional time to complete the surveys. During the second session, they shared that nobody in their teaching experience had asked them this kind of deeply personal information. They appreciated exploring their responses with each other. Teachers anticipated meaningful engagement with other teachers. They were concerned about the disconnection between themselves and their students, but did not report many definite strategies they could use in their instruction to improve their relationship with students. All teachers were consistently passionate, knowledgeable, and committed to improving their practice to improve school for their students.

\section{October Session: White Privilege and African American Guest Speaker}

The October Study was based on the lesson plan contained in the original proposal. The dynamics of this session were intense. Teachers considered White privilege, racism alive today, racialized cartoons, articles from The Oregonian in which race was essentially the story, how to work with angry students, and the difference one teacher can make in the life of a child. The moments of realization emerged when some White teachers shared that they had never had to speak for their own race before. Our African American guest speaker, Miles Strong, was with the group during the viewing of a censored cartoon from YouTube, and the articles assembled since the last session that had appeared in the Oregonian. While Miles was with us, he interpreted some of the stereotypical characterizations in the cartoons. By his body language and comments, he 
acknowledged that he had experienced marginalization as an African American male in our society.

Miles Strong's visit provided teachers a safe space to learn about his experience in his own school career, his beliefs and dedication to helping young African American males in our building through his after school program Boys Reflecting Brotherhood, at Lincoln Middle school. Miles shared his artwork, his class expectations and the Respect Code.

Miles touched all teachers, almost bringing the majority to tears, when he told us about his abandonment, anger and hopelessness all around him when he was a child. Miles said that his grandfather told him that the hand that helps you has no color. During this time when Miles was intensely angry, one teacher forever changed his life. Miles’s teacher literally looked past Miles’s anger and pulled out the best in him. She showed him love and high expectations. Miles said his anger about being abandoned and poor treatment made him so angry that he lashed out.

He linked his experience to the current experience of his students. Teachers in the group learned from Miles about tools they can use when students may call them a racist to keep the focus on learning, to keep learning about their students and not to give up on them. Miles said that students often lash out with no real intention to harm the teacher's feelings. Teachers asked questions and began to consider student realities with a hope for how they could help students change. One teacher decided that he would move a little toward real and tough love. Teachers committed to ask more personal questions to learn 
more about our African American students. Miles offered himself as a resource to all teachers.

When reflecting on newspaper articles, teachers discussed the difference of Black and White life expectancy, the experience of Harvard Professor Henry Louis Gates, Jr. at his home, and the resultant Beer Summit. Miles participated with the group. Teachers wanted more time for small group sharing, but enjoyed the roundtable sessions. One teacher celebrated, "What a delight to carry on conversation with a great peer group." Teachers also reported that this was a great session that would benefit all staff and parents. Teachers recommitted to building relationships with their students. The group indicated that we have come so far but have so far to go in the understanding of race and class.

Marie Montag wrote, “A good reminder of the racism that is still going on in the media and with racial profiling today. It is always shocking that we really haven't gotten farther in our acceptance of each other.”

\section{November Session: Resilience, Race, and Class}

Teachers again said they reflected with others continually since the last session. In analyzing the articles for the week, several teachers tied in the themes to Miles's presentation. Matthew Bill attended the Brothers Reflecting Brotherhood group, as Miles uses Matthew’s room for this after school class. Matthew had never stayed before. While Matthew observed the class, he explored the expectations of Self Enhancement to respect each other. He looked for how Miles interacts with his students within the African 
American culture to explore how Matthew interacts with the same students, many of whom are in his classes. Matthew reflected about this interaction at a deep level.

Building resilience in students and connecting with them was the theme. Teachers wanted to understand the articles from The Oregonian, but the overall struggles of minority challenge, crime and poverty seemed overwhelming at times. During this session, teachers shared stories about talking with students directly about student experience different than their own, even though it was frightening at times. Resilience and how to teach it emerged as a new focus from the conversation in this session.

The art activity for the November session was to divide a paper in half, and to draw engaged students on one half, disengaged students on the other. All drawings included words. There was no apparent pattern of racial identities of students on one side or the other.

One drawing was an abstract cacophony on one side showing confusion, and an organized word-based side: ABC, fun, learning, happy, excited and safe. Another depiction showed a student looking at the teacher with the following words: positive attitude, engaged, notes, supplies, good book, and posture and student planner. On the disengaged side: student is turning away and the following words appear: turned away, inattentive, no engagement, poor posture, note to Pass Class, and no supplies.

In another, students working together are pulling a student out of a hole, forming a human chain to reach the student with a life preserver. The positive side has the following words: adaptable, empowered, prepared, working together. The negative side 
has struggle, feeling alone, and in over your head. Yet another shows a student under a desk, hiding away, and covering his mouth. The other side shows students smiling, working together, and organized. Successful words are: finds good work partners, put together, planner and plans. The unsuccessful side said chronic, worries, bottled up anxiety, problems, needs, unprepared students, empty hand, no expectations, play play play or hide away?

One drawing, by Dora Adventurous, ELD teacher, had no words. Students on the positive side sit at a desk, raise their hands and look happy. The negative side shows a face with a flat affect. Dora said that ELL students want to express themselves but have few words; she felt sad that they faced such strong isolation and that she could not connect with them using words because of the many languages represented. She yearns to make her students feel welcomed. See Table 13 for Art Project word analysis.

All teachers supported each other and were surprised at how much and how their feelings were captured through art. This opened up a new connection among teachers in the group. Each teacher who shared and described a drawing had many hopes and disappointments to share. This sharing went beyond what could have been written about. Clarifying questions helped teachers delve deep into their thoughts in a meaningful way. The group clapped for each person after they shared their artwork. 
Table 13

Art Project Word Analysis

\begin{tabular}{|l|l|}
\hline Engaged Students & Disengaged Students \\
\hline ABC & Turned away \\
\hline Fun & Inattentive \\
\hline Learning & No engagement \\
\hline Happy & Poor posture \\
\hline Excited & Note to Pass Class \\
\hline Learning & No supplies \\
\hline Safe & Struggle \\
\hline Positive attitude & Feeling alone \\
\hline Notes & In over your head \\
\hline Supplies & Chronic \\
\hline Good book & Worries \\
\hline Student planner & Bottled up anxiety \\
\hline Engaged & Problems \\
\hline Posture & Needs \\
\hline Adaptable & Unprepared students \\
\hline Empowered & Empty Hand \\
\hline Prepared & No expectations \\
\hline Working together & Play play play or hide away? \\
\hline Finds good work partners & \\
\hline Put together & \\
\hline & \\
\hline
\end{tabular}

\section{December Session: Ruby Payne, Personal Qualities, and Positive Attributes}

As we discussed the poverty article, Dora Adventurous shared, "When I was

young, I thought we were rich. We had a flush toilet. Wealth and poverty is all relative.”

Teachers connected classroom experiences to the Ruby Payne materials. They

brainstormed ways to move from a clash to a connection with students. The overarching 
realization of teachers is that student negotiates at least two realities - home and school - poverty reality and middle class reality - on a daily basis. They discussed teaching and coaching middle class behaviors as school success behaviors, or teaching students to be positive advocates for themselves. Sid Nye advocated including personalized and positive comments into the progress reports so that each student knows he is giving feedback to them as a person. He has begun giving encouraging comments to students failing or at risk of failing. Each comment begins with the student’s name, such as, “John, you can do it. By applying yourself to every assignment, you may be surprised at what you can do.” Over time, he sees student grades and work improving.

Teachers used surveys and other methods to ask students what really irritates them in class. A surprising response is that students are irritated when asked by others to borrow their things, not wanting to say no to classmates. If they have a special pencil, for instance, and cannot afford many special supplies, they do not want to have others use them and possibly not return them.

Jerry Guy and others talked about increased connecting with students through telling stories from their own lives. Martha Bauridel talked about learning more about her students in environments other than the classroom. She and others worked to learn about personal stories. They went to student basketball games and gave students socialization time - a conscious move from callous to practical to empathetic. Teachers contemplated what students accomplished when they blow out of school by acting in negative ways and get suspended. They worried about if students were safe and fed when away from school. If students are not at school, teachers cannot teach them. 
Resilience research states that the way to teach resilience is to model resilient behaviors. Resilience emerges in people who exhibit positive attributes. Teachers discovered that there is not a magic way - or a how to - to teach resilience. They connected this challenge to other complexities in the art and practice of teaching. This was a Gestalt aha moment for the group.

In one study session activity, teachers used a list of positive attributes shown by resilient people to reflect on their own positive attributes. Teachers highlighted attributes they valued and believed about themselves. They shared those attributes with the group and why they believed those attributes describe them. After a few minutes, they passed the list to the right. As highlighted lists were passed around the circle, more positive attributes were highlighted; teachers were surprised. Some teachers said to others such as the following, "You are totally a risk taker. Why didn’t you highlight that one?”

In the debrief portion of this activity, teachers learned about what they each believe about themselves and the surprising attributes others ascribed to them. Teachers gave positive feedback and encouragement to each other, an attribute shown in the resilience research. Each person developed a goal statement to increase some attributes about themselves. Each person left with a positive attribute card to carry with them and to reflect on as they teach.

Teachers became concerned about progress on their study model projects. This progress was elusive for some, and finding time to complete projects was challenging. Teachers asked some clarifying questions about the study models and expectations for the 
completion of their work. Since February is the culmination month, many teachers began to set times aside to work with each other.

\section{January Session: Leadership and Resilience}

Teachers spent more than half of the session in an animated dialogue focused on the doctoral work of Cox (2004) and on the actions she called for in order to build resilience and success in poverty learning settings. Cox called for leaders to foster resilience in schools by providing

- A caring environment

- Teachers who foster resilience

- Resilience is fostered at the building level

- Enlist community partnerships

- Choice is an aspect of resilience

- Changing paradigms, philosophies and practices Actions called for by various sources to provide a school environment to support students facing challenges and helping them thrive and grow their resilience are:

- The belief that all students can achieve at high levels

- High expectations

- Collaborative decision making access grade levels and curricular areas

- Teachers accept their role in student success or failure

- Strategic assignment of staff - highly qualified

- Regular parent-teacher communication

- Caring staff and faculty 
- Dedication to diversity and equity

- Ongoing assessment in the school and classroom allows teachers to individualize instruction for students

- Frequent assessment with multiple opportunities to improve

- Collaborative scoring of student work

- An emphasis on non-fiction reading and writing

- Aligning curriculum with instruction and assessment

- Collaborative leadership

- Family involvement positively affects student achievement

- Extend the school day

- Ongoing professional development

- Develop autonomy and social competence in students and teachers

The most interesting outcome of this session is that teachers began to connect their daily actions to the long term and complicated goal of fostering resilience in the daily realities of their students and their school. Another group realization is that teaching and resilience are complex. How does one person survive or even thrive in a situation when another does not? How can we help students facing marginalization, poverty, violence or other challenges develop their resilience? In fact, more questions than answers became evident. Some of the attributes were also reaffirming to teachers already working toward collaboration and caring among themselves and in their daily work within their classrooms. 
This session also helped me realize that one of my own goals in improving teacher evaluation is to build resilience within teachers so that they can, in turn, increase the resilience and success of their students. If teachers can love their students across difference and expect them to thrive, the students are more likely to excel.

Teachers spent half of this session sharing their worries that they may not be able to complete their projects for the February Culmination Session. In fact, high performing teachers wanted to get it right. They wanted to learn from the authors about what would constitute a high quality project. Since this was the first time these models were used, a clear explanation or body of examples was not available for them to use.

The other concern participating high performing teachers shared is that they are not mediocre teachers. They perceive that mediocre teachers may just be getting by in their teaching. Conversely, as high performers, teachers had many leadership commitments, university classes in the evening, held students in at lunch and provided support after school, and still accepted new tasks if they perceived the tasks would help the school or the students to improve.

At the end of the session, teachers had individual questions to ask me, and pairs of teachers stayed to touch base with their study partners. They set times to work with each other, or otherwise collaborated. Teachers also mourned the end of the study drawing near. These sessions were described as reinvigorating and necessary to their teaching lives and personal reflection. Teachers valued their ability to shape the experience of the group and the high degree of trust within the group. 


\section{February Session: Culmination Sessions}

Eight teachers attended the first culmination session. One teacher was sick; another had a household emergency. As this session started, teachers shared that they valued collaborating with others, holding a safe space, and learning how to improve their teaching. Sid Nye stated, “These sessions are powerful and necessary. They help us meaningfully reflect on our teaching in a trusting environment.” Teachers were curious about the authors who wrote the pieces that inspired the study models. Teachers appeared worried about their grade, and apologized that their products were not more finished or completed. The group observed that this process shows how complex teaching and learning are.

The group shared the belief that even in excellent evaluative processes, teachers come in one on one to sign their paperwork with an administrator. It is not collaborative. This process helped them continuously think about their teaching in new ways.

The culmination took written, photographic and artistic form. Some teachers wrote out their notes, compiled their work in graphs or charts or just orally shared their experience. Teachers were eager to share their learning with others. One teacher used garage band to voice record the session. With each presentation, attention was given fully to the presenters. Teachers spontaneously clapped after each person or pair presented. Not all groups could present, so a follow up session was scheduled for the following Wednesday.

No exit surveys were completed during the sessions, and while teachers committed to complete the surveys, give revisions to the handbook and write their new 
goals, teachers did not follow through independently. The researcher followed up with email, individual calls, and follow up individual meetings to support teachers to complete their tasks.

\section{Teacher Reports from Study Models}

\section{Educational History}

Lillian Umbaugh, Marie Montag and Ona Clark worked together on the educational history model. They focused on their own Kindergarten through eighth grade experiences as students. They selected this range to parallel the experience in school of their middle school students.

They learned about each other and characterized their educational history as a tapestry. They discovered that their educational experiences as students formed their beliefs about themselves as learners, teachers, and potential leaders. They captured their learning by producing a newsletter-format paper. Their overall commonalities were reported out first, and each person's discrete experience next. The discoveries they made helped them understand the commitment of each other as educators.

All three focused on making school better for their students as an outgrowth of struggles and learning they had as children. They each remembered one or more positive teachers and one or more negative events that motivated them to continue learning. Positive teachers had encouraged them as young students, telling them that they could succeed.

Teachers surveyed sixth and seventh grade students to learn about their educational histories. Students valued the relational aspects of their educational 
experiences. Paralleling teacher survey trends, many students could not recall specific content, but remembered their teachers. Many remembered difficult times and their teacher's responses, both positive and negative. The impact of these responses often set into motion how the students felt about themselves in their current school setting.

\section{Iceberg Model}

Ona and Lillian worked on the Iceberg Model together. They used it to reflect on a student they share. Ona is the Special Education teacher for the student; Lillian is his mathematics teacher. They tracked events, patterns, structures, and interventions they used with the student and how he responded. They tried strategies and debriefed about the student's reactions.

By focusing on positive outcomes and providing structure, they increased student on time arrival and preparedness. The student also found his seat with minimal distraction, decreased shout outs, improved grades, and homework completion. Teachers increased their positive encouragement, rewards for on-task behavior, positive tracking, and minimal detentions or office referrals. The student himself now predicts that he will be able to participate and know how to do work in class. Ona shares, "This model helped mold my reflections...I had to reflect on what could be at the bottom.” She started looking at patterns and beliefs instead of merely noticing or redirecting negative student behaviors.

Beyond time in the classroom, the teachers formed a strong connection to the student's parent. They learned that she has not been able to afford his medications. She 
wants her child to succeed in school. His mother is providing positive reinforcements at home based on the same school goals. The teachers and mother are in continual contact.

\section{SIOP Lesson Planning}

Matthew Bill and Jerry Guy learned that the SIOP model was extremely helpful to them in teaching science, since science is taught with specialized vocabulary. In science, vocabulary clarifies the concepts; without vocabulary, the learning is less precise. Before using the SIOP model together, Jerry and Matthew had not collaborated in their planning. Jerry teaches eighth grade science classes, while Matthew teaches seventh grade science and Lego Robotics. In the past, once in their classes, they were isolated.

They planned their lessons for all classes using SIOP Lesson Planning tools, and found that the strategy helped ELLs as well as students who experience poverty. Neither teacher had used the SIOP Lesson Planning tools with all lessons before. Both teachers acted as resources to each other.

This team shared that although this lesson planning was time consuming, the dividends in more student engagement and student learning was worth it. The SIOP model provided lesson-planning structure for both teachers. While both teachers are adept at connecting with students, the structure assured that they attended to precise aspects of each lesson. Matthew and Jerry debriefed after lessons, sharing discoveries as well as challenges. This format gave them a shared framework, making space for them to discuss their challenges in lesson delivery and student engagement in a precise structure. Also, once having prepared a lesson, that lesson was available to use and change for another application in the future. 


\section{Surveys}

Sid Nye and Jerry Guy used surveys and quick writes to gather feedback from students on a regular basis. They discovered Google Docs as a quick, easy way to set up classroom surveys. Students spent a few seconds clicking in their answers; graphs and outcomes were automatically compiled. Some interesting outcomes that students reported were different than the teachers perceived. In one instance, the teachers perceived one class as too noisy, but the students in that class were content. In another class, students were very dissatisfied with the lack of focus of their peers. Through surveys they learned that students do not like to share their supplies with their unprepared student neighbors. These were both trends that teachers were unaware of before they used surveys.

Students also completed quick writes for their information gathering such as, “What's the cause of all your problems?” It was interesting what emerged and how they learned to change their classroom environment or lessons to engage more students. Sid and Jerry want to continue to use surveys, quick writes and technology to guide their instruction and to learn about their students. They are concerned about data graffiti or data vandalism and if the outcomes will be useful and correct. However, the overall information and feedback they gained was very useful to their practice.

When Matthew Bill learned that these surveys took little time to conduct, and that the tallying was immediate and automatic, he reported,

It just hit me in the forehead working through this process. My use of surveys was so neat that it was another model for us to pursue. It is just a great snapshot. The unanticipated benefit is to learn from Sid how to use the Google docs for the surveys. I will fully use them much more often now. Some kids just get through, but most kids really feel safe to answer questions I am asking them. I got very candid question from kids, such as, “I knew I was lazy. If I didn’t do it the group 
would move ahead. I felt so put down by a bossy person in my group that I didn't answer. " This really helped me guide my decisions. It was a crazy coincidence to look at surveys. I was cursing at my own counting and calculations of surveys. Learning that you can do surveys on a computer in an instant? I cursed again. I just counted all that shit myself. I can use it much more frequently in the future.

\section{Mind's Eye Model}

Dora Adventurous and Sid Nye used the Mind’s Eye Model. Dora discovered how she brings her own identity to the classroom. Sid learned how his experience was different from Dora's and how their experiences were the same. They connected with each other to a deeper level than before the study.

The more Dora examined her own beliefs, the more she consciously brought that reality to the classroom. The more she learned about herself and her own experiences and how they affect her, the more her curiosity about her students increased. Dora interviewed several students about their beliefs, number of countries they lived in, school in the other country, home here and there, the work of their parents and their beliefs. As their English language teacher, she wants all her students to feel welcome and important.

Both Sid and Dora shared insight about the need to be aware of how much they can or cannot share with students. Dora and Sid both shared their own beliefs with the group. They shared what they learned about each other in caring ways. In describing Dora, Sid said:

The Mind's Eye? It has given me some pause. She looks like a little White girl born and bred in the city who was setting off poison dart pig traps to save the pigs living in different people. She feels most comfortable when there is a big mix of people. That makes me think how much stuff do I not know about other people here? It would be wonderful to know about others to appreciate them better. Even the crotchety people - because you could know why they are that way and know their challenges. Just like the students - we don't know what the students are 
dealing with or fleeing from on a daily basis. This work makes me have a much greater appreciation for Dora and other people.

Dora shared a situation that made her reflect on the Mind's Eye to help her contemplate what to do. Dora had a new student this year whose father wants her to wear her head covering at school, but the student takes it off at school, putting it back on before school is out. Should she let the father know, or honor the student's choice to make her religious observation not so obvious with her peers? While she did not come to a conclusion, that one event makes for an example of how complex the decisions teachers make, day in and day out, and how each decision can affect the lives of children.

\section{The Spiral Model of Continuous Improvement}

Martha Bauridel presented the Spiral Model of Continuous Improvement. Dora Adventurous and Martha both used this study method. They both used journaling and hand written notes to complete a spiral. Their spirals were tailored to their work and experiences during the study period. Teachers filled the margins around the Spiral Model with reflective notes.

Martha's role as a Literacy Coach is slightly different than the classroom teacher role. Her job is to coach her peers to improve lessons and student outcomes. She noticed what she otherwise would not have thought about by using the spiral. Martha used colors and words to reflect on an interaction with a teacher, what she did, the outcome, and how the whole process could change. Her ultimate goal emerged in the process: to make teaching and learning more effective for students.

Dora Adventurous anticipated larger classes this year, and decided to add organization and routines to her teaching. Her increased classroom organization led to 
teaching students to organize their work and notebooks. She determined through using the spiral that morning groups could handle small groups and partner conversations whereas the afternoon groups still could not. She added positive motivation and feedback, drew prizes and saw resultant higher student engagement. When she began rewarding the class as a group, the class self regulated. In her last coil of the spiral, students were able to earn one minute early The class earned the privilege release if all of the class made the goal, and the class left one minute early three days in a row. Dora determined to continue the focus on expectations, routines and positivity to shape the climate for learning.

\section{Community Visits}

Lilly Strong, Marion Reliant, and Marie Montag conducted community visits. While they did not follow the community visit model as presented in the handbook, they did explore the community from their perspectives. Conducting home visits, going to area churches, or other activities may have to be supported to a higher degree for study participants to be able to engage at such a deep level.

Lilly attended Lincoln as a student, and reflected quite a bit on the changes in the community and in the school since she attended. She drove around the area. She remembered her experiences in the neighborhood as a child and compared and contrasted those with the current reality students face today.

Marie Montag began taking photographs and driving the school’s attendance catchment area. Marie connected her passion for photography to the work. She learned about one of her students and the student's mother. They finally will qualify for a Habitat for Humanity home. Marie drove to the location of the home and took pictures, imagining 
how the house will change when occupied by a hopeful, thankful family. Marie compared the pockets of poverty and wealth. She also thought about what it would have been like to have grown up in various areas of the community.

An unexpected event in Marie’s life led to a personal interaction with the community. Marie’s dryer broke. She began taking her laundry to a local Laundromat. She saw her students and their families there, and thought about the chore of carrying the laundry as well as the economic impact of paying for laundry for a family. Marie began visiting a Mexican bakery, or panaderia, close to the laundry. Although she does not speak Spanish, she began to say, hola, and the store folks got to know her. Marie gained new awareness and appreciation for the Mexican culture, and looks forward to the laundry experience, even though it is inconvenient.

Marion Reliant did not do formal community visits, although he has conducted home visits in the past. He felt that he might have been viewed as an intruder, and that students often come to school hiding the challenges they face in their personal lives. He was also nervous, and reports feeling unsafe. Marion shared

I wanted to do home visits but I sensed that without a larger structure to make it a regular thing especially with families in crisis, it is not a good idea. A lot of people have strange places right now. I didn't feel personally safe or it would make the family feel strange. I did replacement work like observing some interactions with what is happening in the home and how it affects me in the classroom. Families are pretending that everything is normal and it isn't. Kids are crying and begging you not to let parents know that you know.

\section{Democratic Attributes}

Marion Reliant worked with Matthew Bill on democratic attributes. They both reflected on the tension of holding a democratic space and the tension of being the 
teacher in charge of classroom learning. Marion Reliant's advanced reading group did not have enough copies of the upcoming novel for the class. The students came up with a solution that included all students and let the group move forward. Marion appreciated this moment, and reported a different awareness of the group dynamics by using the democratic attributes model as a lens to reflect on his teaching.

Matthew Bill said that realizing democratic attributes in class can be elusive. He teaches a class using exploration. Lego robotics makes group work essential, and the democratic attributes helped the groups experience including all members as a democratic value. Although his other study, the SIOP model, provided structure for lesson planning, Matthew reflected far more on the democratic attributes. He shared:

The democratic attributes made me focus on the kids, their self-confidence, and their trust within their groups. That was huge for the kids. Kids are not willing to take risks in their work in the classroom. They want to be led by the hand. If everyone's ideas are valuable and you can respectfully include their opinion - that supports democracy. For kids, the loudest one at home gets heard. That is what you see in groups. Kids started developing that understanding. We need to do this way earlier than seventh or eighth grade. The fact that they don't feel comfortable sharing their feelings is nuts. The Democratic Attributes is what I have been about since I started being a teacher. The kids are comfortable, respectful, talking to each other and asking each other questions before they come to me - it is an alien thing to most of them. I started noticing big differences. I would like to talk to other teachers about how the same students changed in their other classes.

\section{Overall Trends from Study Model Presentations}

The handbook provided options to help teachers engage in critical, abstract reflection. Teachers shaped the lessons, collaboratively developed their learning projects and products, and created an open dialogic space. They changed the handbook by eliminating traditional teacher evaluation models. They connected professional development to teacher evaluation called for by Iwanicki (1998), and described their 
reflection between learning sessions as ongoing and embedded in their thinking. These teachers explored problems from many perspectives, generated alternative plans, and chose a plan for themselves Glickman (2002). Lillian said that she viewed classroom events with her students differently as a result of her work in this study. Lastly, teachers became lovingly angry about the achievement gap experienced by their students, and changed to better connect with them (Shields, 2003). Teachers also openly and publicly committed to loving each other. Sid asked, "How much more can we accomplish in our school if we know all of our colleagues who were not in the group in the way we now know each other?”

All study models were designed to improve teachers and student connections crucial to student learning in the classroom (Darling-Hammond, 1997; Nieto, 2002; Wood, 1998). They comprised a structure for teachers to explore their enduring, situated and endangered selves (Spindler \& Spindler, 1994). Teachers were motivated to consider their students' selves. Involving teachers to develop, interact with, and control the topics for study was central to the design. When teachers experienced agency, they committed to do the very hard work of defining and redefining their position, selves and teaching capacity.

All teachers found their study models helpful. Most models proceeded as designed. The least-developed study was the community visit option. Teachers found community visits daunting; teachers were concerned about being too intrusive. Teachers observed that some models were very loose and touchy feely while others fit better with teachers who needed more structure. Teachers appreciated that they had a variety of 
options that they could choose from, and that they had others to learn with. High

performers are hard on themselves, and some did not want to turn in their products

without a chance to make them better or more complete. It was parallel to the student behavior of wanting reassurance and structure in order to earn an $A$ on a project or in a course. These high performing teachers acted like students who jump at the chance to do extra credit to improve their grades.

\section{Trends from Exit Self Surveys}

Unfortunately, most of the Exit Self Survey questions appeared redundant, and most outcomes were integrated into study sessions and culmination presentations. All participants wanted to continue the sessions. They wanted to further evolve their teaching. They consistently wanted more time for the work and for reflection to be built in to sessions. The following quotes capture typical yet poignant points.

Jerry Guy committed to connecting more closely with his students as a result of this experience. He wrote:

Dive into the background. I've always understood that a student in a classroom is an incomplete total package. However, I've always thought that it was up to me to control everything that went on - but I can't, and it would beat me up. Watching this group dive deeper than I ever had into a student's life is inspiring. There is now way that I could predict what is going on in a student's life to be an effective educator toward them, unless I dedicate the time to learn about the child first. I plan to communicate and listen to student - What is in their background? Knowing their perspectives controls the way I direct my lessons.

Sid Nye learned that it is all about the relationships:

To be a better teacher, you need to know your audience. It is easier to assist a student if they trust you. This takes time. I wonder if this is a powerful argument for looping. By the time you get to know your students, they are gone. Then it is time to build new relationships. 
Marie Montag learned about our perceptions:

We each perceive differently, but this group is open to re looking at what we do and how we do it. I am also impressed at how our perceptions have changed about our teaching, classrooms and the families we work with. I plan to continue to build relationships with my students' families.

Lilly Strong planned to continue reflecting, writing and observing what happens

in the students' community. She appreciated the chance to reflect. She said, "I was

reminded how personal reflection is, even when it seems so structured on paper.”

Marion Reliant shared

I want to share my impressions. This is my first time around with my reading group, so I am like a first-time teacher applying what I want from the program to what I was creating from scratch. It did help direct my thinking. Working in a PLC with a bunch of colleagues from different areas with the same thematic core questions, meant that I felt refreshed, refocused, and invigorated. This is a way I don't feel when I have a one-day wonder in-service. The model of continuous improvement was valuable, certainly much more than traditional evaluation techniques or a one day in-service A principal who really wants staff to think about these issues, talk about it, go away and come back will get a lot more value out of this effort. It is a huge time commitment. I don't know how to resolve that.

Matthew Bill responded

As a teacher, it was more work, but it kept me thinking about it all the time. Someone watching me two times a year? Don't see how it gives you the education or the administrator a real view of how you can really improve. You see folks and you wonder how they have been doing it that way so many years and just doing the minimal?

Self-evaluation over the course of months is worth it. You look far out. It is costly to put in a much more costly evaluation system. What is it costing us to have teachers who are not making the grade? It is a much higher cost to the students in their long-term future.

\section{Goal Setting Process}

Goal setting forms completed by teachers included their desire to continue working with their models in the future. Two set mutual goals on their individual forms. 
All teachers plan to continue collaborating with members of the group, whether or not they share students or curricular areas with their colleagues. However, only 4 of 10 teachers completed Goal Setting Forms. I believe this is, in part, because I am not their principal.

The study was planned so that the researcher and facilitator would be the collaborative principal of the teacher group. Once the researcher's role changed to the district office role, then teachers had little urgency to complete goal setting forms different from district forms. They knew they would have to set goals and meet with their new principal or assistant principal in the fall of each year. Most importantly, teachers need to be in good standing with their principal. Teachers completing the goal setting form found it a bit artificial, but completed the form "for your study."

Two teachers set goals beyond the scope of evaluation. They both said that their work in the study motivated them to learn more. Matthew is enrolling in a master's program to begin in the fall following the study. Sid is contemplating applying to a doctoral program.

\section{Unanticipated Challenges Faced During the Study}

Planning the sessions, starting on time, keeping focus, and planning for the appropriate amount of material to present or discuss was difficult. It mirrored the challenges teachers face in planning lessons for the classroom. In most sessions, teacher behavior was focused and intense. Teachers indicated that embedding time to work on study models and including more firm expectations and timelines would have been 
helpful to them, although the balance of freedom and definition is difficult, especially in a new process.

Behaviors such as late arrival and note passing on the part of teachers were infrequent, but mirrored challenges teachers have in the classroom. Dialogue in initial sessions was somewhat guarded. As months progressed, conversation was richer, and topics moved from sharing observable events to trying to unravel deeply held beliefs of students, how experiences influence us, and how to connect with students and families in specific ways.

Another unanticipated challenge was the role of the researcher in relation to the teachers in the study. As I was no longer their principal, the teachers had to pay attention politically to their interactions with their new principal. This added complexity to the study not initially anticipated. In any case, the role of facilitator in the study sessions did help teachers make progress. The facilitator is essential in planning the next lesson, purchasing dinner, listening well and safeguarding a climate of openness for teacher reflection and dialogue.

The structure of the learning sessions was a benefit to teachers. Having an agreed upon time to meet, a dinner, and an agenda with materials to read in advance of the meetings enhanced the learning sessions. Most of the participating teachers were familiar with professional learning community structures, and had participated in one or more professional learning community groups in the past. One teacher used the professional learning community structure to begin reflecting on the efficacy of each of his classes using a professional learning community approach as a lens. 


\section{Conclusion}

Teachers deemed this process respectful, inclusive and transformational. It moved them from teachers who had evaluation done to them to teachers who conducted their own evaluations (Peterson \& Chenoweth, 1992; Woods, 1998). Teachers committed to understanding their students and each other in new ways (Shields, 2003). The walls between their classrooms and each other became permeable (Peterson et al., 2002). They valued collaboration over traditional teacher evaluation, and built lateral capacity by working in new ways with their peers in partners and in the study group. Dora

Adventurous aptly captured her experience and the group experience in her Exit Survey,

This self-study experience was more meaningful for me than the traditional observation process, because I did a lot more reflective thinking. Collaborating with other teachers was a powerful way for me to grow personally and professionally. I would like to have more collaborative learning experiences with other teachers. It's easy to become isolated as a teacher. Sharing ideas and experiences is energizing, and it makes the team more effective... None of us sees the world exactly the same way. I have to get to know my students and not assume things about them based on my cultural views. I have had an opportunity to learn more about my students through the Mind's Eye self study model. I am curious about how to relate to my students and co-workers with greater understanding of them and myself.

Already passionate as a group, teachers gained insight, compassion, and caring for their students. Teachers in this study put into practice an open dialogic space of communal reflection (Bohm, 1996; Schwartz, 2001; Wheatley, 2002) in which they openly reflected about how to develop their practices in response to our current reality in school. Participating teachers also examined their own values, beliefs and customs that were formerly unexamined. This is a step that Zhao (2009) called for in the work of understanding others across cultures. In a few months of sessions, and reflective dialogue 
using models to examine their teaching, cross cultural proficiency and resilience emerged as two consistent themes.

In retrospect, the amount of material in the handbook combined with the readings for the sessions was too much material for the allocated time. Timelines were based on the district evaluation calendar. This calendar did not lend itself to deep reflection or the time it takes to receive and analyze student testing outcomes. 


\section{CHAPTER V}

\section{OUTCOMES AND IMPLICATIONS}

Ten high performing teachers conducted a self-evaluation cycle using new study models in a pilot handbook, Teacher Evaluation Handbook: Self Evaluation for High Performing Teachers. This was the field test portion of a problem based learning model study reflecting on how to improve teacher evaluation for high performing teachers, connect teacher evaluation to professional development, and to improve school for all students so that they will be literate and able to negotiate their own future in our democracy (Dewey, 1944; Freire, 1973; Giroux \& Giroux, 2004, Iwanicki, 1998).

This study is important because teaching is complex, and many efforts are underway to improve schools for all students; and because in reform efforts, teacher evaluation is noticeably absent (Danielson, 2002; Iwanicki, 1990; NCLB, 2002). This work addresses a real problem in practice: how to make teacher evaluation meaningful for high performing teachers, who generally find teacher evaluation a meaningless, non event (Palmer, 1997; Peterson, 2000). Teachers reported that this study helped them improve, and because they worked with others, the informal conversations with peers in a kind of professional learning community structure (Blankstein, 2004) helped them sustain their focus on change.

High performing teachers in the study were passionate, life long learners who committed to improving their practice whether or not they experienced a formal a formal 
evaluation process. This study gave them the chance to move from being receivers to conductors of their own evaluation, a move from traditional to transformative evaluation (Pajak, 2000; Wood, 1998). Another action teachers took that moved them to a transformative arena was that they embodied the attributes of an exceptional teacher, as defined by Tucker and Stronge (2005):

Exceptional teachers... made school an exciting and interesting place. Those teachers possessed a passion for the subjects that they taught and genuine care for the students with whom they worked. They inspired us to play with ideas, think deeply about the subject matter, take on more challenging work, and even pursue careers in a particular field of study. (p. 1)

All 10 teachers described passion as essential to their teaching. They yearned to engage all students in learning. Caring for all students, they urgently wanted to create an environment of high engagement and rigor (Daggett, 2008). For many of them, teachers changed their lives in their early years of education.

Participating teachers engaged in what Anderson (2002) referred to as, “intentional systematic, self-reflective practitioner research” (p. 22). Teachers took on the responsibility of rigor. Teachers generated ideas, took charge of their learning, worked independently and together, persevered, were creative, and planned to continue using transformative study models. Teachers reported that they constantly reflected in the study sessions, between sessions and in their classrooms about how to improve school for their students (Lunenberg \& Ornstein, 2004). Teachers built their leadership capacity, and acted as resources to themselves and each other throughout the duration of the study (Knowles, 1984; Lambert, 1998). In fact, they valued collaboration and a lessoning of 
isolation (Heisinger, 1994; Peterson, 2000). The collaboration they experienced motivated them to learn even more.

These overall outcomes indicate that transformative teacher evaluation in which teachers have time to collaborate, analyze their practice and view the learning environment from various perspectives can make teacher evaluation more meaningful. As an outcome of this first step, I am certain that teachers hold overlooked answers about how to improve schools for all. Teacher experiences in the study show that teachers sought to engage students to a higher level, and to understand the learning environment from the student perspective. This school and others like it must improve, because with education, students can engage in a bright future and escape their apparent destinies (Danielson, 2002). If one believes that engagement is a crucial element to learning, then the teacher actions in the study to seek increased engagement in a safe, rigorous, loving environment is a first step toward increased student outcomes.

\section{Creation of the Handbook and Changes During the Study}

The researched and teachers collaborated to develop the handbook. The teachers in the study were primarily members of a multiple-year leadership team using a professional learning community process to meet for the purpose of improving school. These teachers are used to analyzing data, making plans and measuring outcomes. Prior to this study, they had considered continuous improvement as represented by The Spiral Model, and had used the Iceberg Model to begin to understand the complexity of personal identity in decision-making. Participating teachers had some experience sheltering their instruction for ELL students. The researcher from literature regarding 
transformative supervision and evaluation developed remaining models contained in the handbook. The central framework was to help teachers explore transformative teacher evaluation in order to be able to examine their own teaching in new ways to benefit their students.

Teachers read and helped revise the handbook before beginning the study; the handbook is less academic and more applied in its orientation than earlier versions. While the handbook looks easy to use, teachers discovered that questions of engagement and improvement are complex. At the end of the study, teachers asked for additional research information that guided the development of the models. Teachers wanted to continue the project, but also had other responsibilities that occupied their time and focus.

\section{Benefit of Problem Based Learning}

In this study, teachers were the principal investigators of an ill-defined problem: how to improve teacher evaluation and connect it to improving school for students. This is a real world problem, as these teachers consistently reported that teacher evaluation had not been an opportunity to learn or improve in the past. Additionally, they sensed a disconnection from their students that they wished to decrease. Teachers were self directed, able to use multiple sources of data, self-motivated, proactive, and able to work as a team. Their emphasis was on meaning and long-term growth, not just on checklist or gathering of proof of their work. Teachers shaped and owned the study, its content and their work. 
Marion valued his participation, and wrote, “The study was an opportunity to step back, be reflective and capture your experiences with your students. The study was open ended and welcoming, not a task to be completed.”

\section{Research Questions and Findings}

- How can teacher evaluation be meaningful?

- How can it contribute to improving school for all?

- Will teachers connect across difference with their students in new ways?

- Does transformative evaluation make a difference?

Table 14 summarizes teacher responses to the research questions. All teachers found that this model and studying together were more meaningful than past teacher evaluation experiences. It connects professional development to teacher evaluation. Embedded in all of their observations were their efforts and hopes to help students succeed, and their discoveries about how to engage students. In fact, in their entry surveys, teachers valued collaboration, information and practical application in their significant professional development experiences; they also had plans to further their knowledge and efforts to help all students succeed.

The teachers all believed that connecting with students and understanding their students’ perspectives would improve school. No teacher report focused on data driven outcomes, although all of the teachers used summative and formative evaluation information to inform their instruction on a regular basis. Over half of the teachers committed in their culmination session presentations or in their goal setting to continue to use their model of study or to use a model presented by a colleague. Teachers all reported 
that their students need to believe in them and connect with them, and that they need the

tools to look at student realities in new ways.

\section{Table 14}

\section{Teacher Responses to Research Questions}

\begin{tabular}{|c|c|c|c|}
\hline $\begin{array}{l}\text { Teacher } \\
\text { name }\end{array}$ & $\begin{array}{l}\text { Meaningful Teacher } \\
\text { Evaluation }\end{array}$ & $\begin{array}{l}\text { Improving School and } \\
\text { Connecting to Students }\end{array}$ & $\begin{array}{l}\text { Transformative } \\
\text { Evaluation }\end{array}$ \\
\hline Sid & $\begin{array}{l}\text { I learned that it is all about } \\
\text { relationships. I connected } \\
\text { with others in the group. } \\
\text { How could our school } \\
\text { change if we could all } \\
\text { connect in this deep } \\
\text { meaningful way? }\end{array}$ & $\begin{array}{l}\text { It is easier to assist a } \\
\text { student if they trust you. } \\
\text { This takes time. }\end{array}$ & $\begin{array}{l}\text { I just received a } \\
\text { summative evaluation in } \\
\text { my box. I thought, "So } \\
\text { What?" What a delight to } \\
\text { carry on conversations } \\
\text { with a great peer group }\end{array}$ \\
\hline Jerry & $\begin{array}{l}\text { I thought before that } \\
\text { students were incomplete } \\
\text { packages. There is no way I } \\
\text { can predict what is going on } \\
\text { in a student's life to be an } \\
\text { effective teacher, unless I } \\
\text { dedicate time to get to know } \\
\text { the learner first }\end{array}$ & $\begin{array}{l}\text { Communicate and listen } \\
\text { to students. Knowing their } \\
\text { perspective helps me } \\
\text { change the way I plan my } \\
\text { lessons }\end{array}$ & $\begin{array}{l}\text { Previous evaluations felt } \\
\text { artificial. I wrote or said } \\
\text { what they wanted to hear. } \\
\text { This process is all on my } \\
\text { shoulders. I feel the } \\
\text { responsibility for my } \\
\text { growth. I am not trying to } \\
\text { please an administrator }\end{array}$ \\
\hline Marion & $\begin{array}{l}\text { I really connected with } \\
\text { others. It was essential, not } \\
\text { merely an added task }\end{array}$ & $\begin{array}{l}\text { If we commit to know our } \\
\text { students they will trust us } \\
\text { and want to learn from us }\end{array}$ & $\begin{array}{l}\text { Open ended sustained } \\
\text { reflection. I will move a } \\
\text { little toward real and } \\
\text { tough love }\end{array}$ \\
\hline Matthew & $\begin{array}{l}\text { We develop tunnel vision. It } \\
\text { is so important for me to } \\
\text { learn from more } \\
\text { experienced teachers. There } \\
\text { is so much to improve on. I } \\
\text { learned that students can act } \\
\text { out with no real intention to } \\
\text { harm my feelings. }\end{array}$ & $\begin{array}{l}\text { Provide all students a } \\
\text { unifying vision of what } \\
\text { they can accomplish. My } \\
\text { cultural values clash with } \\
\text { student values. We need } \\
\text { to look at school from the } \\
\text { kid's point of view }\end{array}$ & $\begin{array}{l}\text { Evaluation had no } \\
\text { meaning to me in the past. } \\
\text { I don't see how someone } \\
\text { watching me two times a } \\
\text { year ... can give you a } \\
\text { view of how to improve. } \\
\text { Self-evaluation over the } \\
\text { course of months is worth } \\
\text { it. }\end{array}$ \\
\hline Dora & $\begin{array}{l}\text { I did a lot more reflective } \\
\text { thinking. I also collaborated } \\
\text { with other teachers. }\end{array}$ & $\begin{array}{l}\text { I need to know all of my } \\
\text { students' cultural views. I } \\
\text { have not experienced } \\
\text { racism like many of my } \\
\text { students have. }\end{array}$ & $\begin{array}{l}\text { Collaboration was a } \\
\text { powerful tool }\end{array}$ \\
\hline Martha & $\begin{array}{l}\text { I learned to act plan and } \\
\text { reflect on my practice }\end{array}$ & $\begin{array}{l}\text { Reflect on my } \\
\text { performance related to } \\
\text { school goals }\end{array}$ & $\begin{array}{l}\text { More relevant than } \\
\text { opportunities to be } \\
\text { evaluated in the past }\end{array}$ \\
\hline
\end{tabular}


Table 14 (continued)

Teacher Responses to Research Questions

\begin{tabular}{|l|l|l|l|}
\hline $\begin{array}{l}\text { Teacher } \\
\text { name }\end{array}$ & $\begin{array}{l}\text { Meaningful Teacher } \\
\text { Evaluation }\end{array}$ & $\begin{array}{l}\text { Improving School and } \\
\text { Connecting to Students }\end{array}$ & $\begin{array}{l}\text { Transformative } \\
\text { Evaluation }\end{array}$ \\
\hline Lilly & $\begin{array}{l}\text { In my quest to know the } \\
\text { unknown and see the } \\
\text { unseen, I learned about my } \\
\text { students and myself }\end{array}$ & $\begin{array}{l}\text { The relationship between } \\
\text { the teacher and student } \\
\text { makes up at least half of } \\
\text { the determining factors of } \\
\text { success }\end{array}$ & $\begin{array}{l}\text { I worked with others and } \\
\text { learned }\end{array}$ \\
\hline Lillian & $\begin{array}{l}\text { We get stuck in our own } \\
\text { view and need to see } \\
\text { through the cracks }\end{array}$ & $\begin{array}{l}\text { Making relationships with } \\
\text { students is so important }\end{array}$ & Collaboration is powerful \\
\hline Marie & $\begin{array}{l}\text { My perceptions have } \\
\text { changed about my teaching, } \\
\text { the classroom and our } \\
\text { families }\end{array}$ & $\begin{array}{l}\text { Racism our students face } \\
\text { is shocking. I will stay } \\
\text { encouraging and } \\
\text { supportive to my African } \\
\text { American students }\end{array}$ & $\begin{array}{l}\text { The discussions were } \\
\text { open. I wish we could } \\
\text { have continued and that } \\
\text { more people were } \\
\text { involved }\end{array}$ \\
\hline Ona & $\begin{array}{l}\text { I believe that students need } \\
\text { to feel better about our } \\
\text { school. If they do, they may } \\
\text { try harder }\end{array}$ & $\begin{array}{l}\text { I will continue to } \\
\text { collaborate with others. I } \\
\text { am overwhelmed. I want } \\
\text { to learn to not get burned } \\
\text { out }\end{array}$ & $\begin{array}{l}\text { This process was } \\
\text { collaborative and helped } \\
\text { us make a huge difference } \\
\text { in the hopefulness and } \\
\text { engagement of our } \\
\text { students }\end{array}$ \\
\hline
\end{tabular}

\section{Efficacy of Study Options}

The Handbook for High Performing Teachers is a prototype. It was developed locally and used only once by 10 teachers and an administrator for 7 months.

Nonetheless, all teacher participants found the models they used helpful to them and their work in classrooms with students. Consider the following information in Table 15. All teachers engaged with their models and applied their learning to the classroom. Some models were modified greatly, while others were used as presented. 


\section{Table 15}

\section{Study Models and Teacher Comments}

\begin{tabular}{|c|c|}
\hline Study Model & Teacher Comments \\
\hline Iceberg & $\begin{array}{l}\text { Lillian - It is so powerful to learn what is going on below the surface } \\
\text { Ona - We were able to restore hope for our student. He believes he now has something } \\
\text { to add in the classroom. Now, his mother is working with us to help her son succeed. } \\
\text { This model helped mold my reflections - I had to reflect on what could be at the bottom }\end{array}$ \\
\hline Mind's Eye & $\begin{array}{l}\text { Dora - I identified my beliefs and compared my beliefs with my student beliefs. This } \\
\text { helped me rethink my teaching. } \\
\text { Sid - Dora? She looks like a little White girl born and bred in the city...She was setting } \\
\text { off poison dart pig traps to save them when she was a little girl. How much stuff do I } \\
\text { not know about people here? }\end{array}$ \\
\hline Surveys & $\begin{array}{l}\text { Sid - Surveys showed me that students could be completely happy and engaged, but I } \\
\text { was perceiving the classroom differently } \\
\text { Jerry - If they are quick, surveys can act as formative assessments to inform my } \\
\text { instruction }\end{array}$ \\
\hline SIOP & $\begin{array}{l}\text { Jerry - Using this structure to organize my lessons really helped me assure that I was } \\
\text { consistently teaching an entire lesson } \\
\text { Matthew - I can use these plans again and recalibrate how lessons work }\end{array}$ \\
\hline Democratic & $\begin{array}{l}\text { Marion - It is interesting to help children negotiate challenges and not step in to solve } \\
\text { the problem. You are more like a democracy coach. } \\
\text { Matthew - I focused on the kids, their self-confidence, and their trust within the groups. } \\
\text { Kids became comfortable, respectful, and ask each other questions before they come to } \\
\text { me - it is an alien thing for them. }\end{array}$ \\
\hline Spiral & $\begin{array}{l}\text { Dora - Using the Spiral, I reflected on how routines and class practices worked or } \\
\text { didn't. I engaged with students in brainstorming solutions so that our class would run } \\
\text { smoother. Peer pressure and buy in worked. } \\
\text { Martha - Using the Spiral Model as a frame of reference to coach a teacher, I told him } \\
\text { to follow his instincts but also to reflect on the efficacy of the lessons. It was an Aha } \\
\text { moment. How can I build the capacity of staff to evaluate, plan, reflect and repeat? }\end{array}$ \\
\hline Home Visits & $\begin{array}{l}\text { Marie - My dryer broke. I began taking my laundry to a Laundromat and ran into our } \\
\text { students. There was a Panaderia nearby. I go in say hola, and order; they smile. I am out } \\
\text { of my comfort zone and learning } \\
\text { Marion - Home visits... I didn't feel personally safe, or it could have made the families } \\
\text { feel strange. Kids are crying at school and begging you not to tell their parents. }\end{array}$ \\
\hline $\begin{array}{l}\text { Educational } \\
\text { History }\end{array}$ & $\begin{array}{l}\text { Lillian - Mr. Gomez told me many times that I had opportunities and that I didn't need } \\
\text { to be bound by what life was giving me right now. } \\
\text { Marie - I would have done anything for Mr. Grey. He made learning fun and } \\
\text { interesting. I learned to use a spelling dictionary. This saved my life. } \\
\text { Ona - I was placed in Special Education and I hated leaving my class to go to the smelly } \\
\text { class. Now I am a Special Education teacher. }\end{array}$ \\
\hline
\end{tabular}


Because of their success and products, each model merits being used again to determine if a replication of the models will produce the same outcomes. Each study model acted as a lens or prism teachers used to consider a new reality or experience. Teachers wanted to understand their students and each other more fully, Even so, this work is limited, as Schwartz (2001) wrote, "W e can only understand another cultural perspective through the prism of our own cultural categories, and therefore any attempt to enter another cultural perspective can only be partial.” In spite of this limitation, participants openly shared and examined their own biographies. They celebrated discovering diversity of identity and experience within their group. They consistently described that the sustained reflection in this study was more meaningful than a one-day seminar or a three-visit observation cycle.

\section{Models, Intent, and Outcomes}

\section{Iceberg Model}

This study option was designed as a visual representation of the complexity of thought. Because only $10 \%$ of an iceberg is visible above water, there is little we can determine by looking above the surface. The above-the-surface view is generally how we gain information about classrooms, race, and observable actions. Below the surface we can determine patterns and structures that predict behavior. At the deepest level, we make decisions based on our beliefs that often are not evident to others. I anticipated that teachers would spend time at all levels of the Iceberg, and that they would analyze an event or a goal in their teaching. However, the teachers who used the model share the same struggling African American sixth grade student. They used the Iceberg to analyze 
his behavior, to work with his mother and to get to know him. Their ultimate goal was achieved when they changed his initial self-concept of a student who had nothing to offer in the learning environment of the classroom to a self-belief of efficacy. This was accomplished during the limited time of this study.

One teacher shared a moment when a student was so upset that he accused her of picking on him and hating him. Instead of internalizing this moment, blaming the student, or disengaging, the teacher anticipated helping her student. She teased out the underlying cause of the student's anger and frustration. Then she provided him with a redirect so he could turn around his day. This is an act of love.

\section{Mind's Eye Model}

The figure of the Mind's Eye makes hidden beliefs visible. Wink and Wink (2004) developed this figure to show how their love of literacy developed. They realized that race, religion, class, experiences, gender and other factors influence how we interact with the world. The Mind's Eye places these beliefs behind a figure of an eye. In this way, they show that how we read the world is individually framed.

I offered this model to teachers hoping that they would use it to explore their own beliefs and identities, and then compare or contract their beliefs with the beliefs of their students. This model worked very well. Two teachers learned far more about each other by completing their Mind’s Eyes. Then, one teacher interviewed her students, learning about the students' Mind's Eyes. An unanticipated benefit of this model is that it gave a teacher who is normally very shy and tentative the courage to bravely tell the group who she is. The Mind's Eye acted as a shared language to frame her explorations. 


\section{Surveys}

The surveys presented in the handbook come from Peterson (2000). He suggested that teachers can learn about their teaching by eliciting various sources of data. I

presented the student survey questions and parent survey questions with an explanation of how information gathered from surveys can provide teachers with formative evaluative information. I asked them to use the student surveys, and offered the parent surveys as optional.

Two teachers used this model. They used the student questions as they appeared. One teacher tabulated responses by hand, while the other initially made booklets by hand with student responses. Later, one teacher discovered Google Docs, and set up a survey station in his room. The program tabulated all answers, and each survey took only minutes. Subsequently, teachers wrote new survey questions and tabulated them. Student warm up questions became formative information also used as survey information to inform instruction.

\section{SIOP}

The SIOP was developed to benefit ELL students in the classroom. This is a lesson planning or observation tool that assures that picture cues, anticipatory sets and practice with others is built into each lesson. Because the outer urban middle school in this study has an enrollment of more than 35\% ELL students and more than $75 \%$ of poverty, I believe this model holds promise for both groups. Poverty students and ELL students both face the challenge of limited academic vocabulary necessary for school success. 
Because teachers using this model were teaching science, they found it particularly helpful. Science has discrete and complex language that students must master in order to engage in lessons and understand the content at hand. Also, teachers reported that they planned all of their lessons using SIOP, delivered the lesson, and debriefed. So, in this regard, their use of the lesson-planning tool was recursive, an attribute more central to the Spiral Model of Continuous Improvement.

\section{Democratic Attributes}

This model offers a list of the attributes of democratic education developed by Apple and Beane (1995). Because I believe that a democracy is impossible without an educated populace, and that democracy is essential to our public school system, democracy is incredibly important to me. I merely offered this list for teachers to use in reflecting on their teaching.

Teachers using this model went deeper than I imagined. They described this model acting as a lens they used when guiding student interactions in the classroom. Middle school students whose teachers used this model began to share, care, and negotiate their learning with their teachers. Teachers described that middle school students began to think of the good of the whole, and not just their own interests in a situation.

\section{Spiral Model of Continuous Improvement}

Teachers in the study group had contemplated the Spiral Model of Continuous Improvement before engaging in this study. The recursive spiral figure was adapted from 
the work of Chenoweth and Everhart (2002). The spiral allows for learning that is not merely circular, but iterative. To use this model, teachers act, reflect, plan and act. Teachers who used this model reflected on different areas of their work.

One teacher used it to analyze her actions and how they elicited behaviors of engagement or disengagement of her students. The other used it to capture her coaching experiences and to clarify her mission statement in her work.

\section{Home Visits}

Teachers rarely live in the location of the school in which they teach. In Lincoln Middle School, only two live in the community. What was once a White upper middle class neighborhood with truck farms, suburbs, and drive-ins has become filled with block upon block of dense apartment complexes. As a transit line connected the inner city with this area, the transit line brought crime, poverty, and diversity to a central core.

I believe that if teachers can understand the environment in which students live, they may understand their students differently. At least, they may be able to make their instruction more relevant to their students. I developed this model to encourage them to explore the living environments of their students when students are away from school. Teachers were asked to complete five steps with increasing levels of venturing out: (a) drive the attendance area and reflect, (b) visit our other two middle schools and then compare and contrast, (c) go on a home visit with a social worker or counselor, (d) ride

along with our Student Resource Officer, and (e) visit a church service with a student and his or her family. Teachers also could develop another protocol for visits. 
This model was the least successful. The study was designed to start with an easy initial activity followed by more involved and personal subsequent visits. If I had been the principal during the time of the study, I could have taken a teacher's class or facilitated cross-district or home visits. Also, I believe that teachers had a fear of entering the community on their own. In retrospect, a pair of teachers visiting a community location together could have reassured the teachers, who may have moved beyond the first step of driving the neighborhood and reflecting.

Teachers drove the attendance area, and one teacher recorded her experience by taking photographs. Because her dryer broke, a teacher decided to use the local Laundromat in the area in which her students live. She was able to interact with them and their families, and discovered a Mexican bakery, or Panaderia, that she began to visit regularly. She ventured out of her comfort zone, even beginning to use simple greetings. The other teacher engaged deeply and had made some home visits in prior years with me, but was uncomfortable to do so on his own. Both teachers were hesitant to visit students in their homes, at churches or at night.

\section{Educational History}

Because teachers often teach based on the teaching they experienced as children, I developed this model to help them reflect about what teachers they had, why they remember their teachers, and how they felt, etc. My goal was to have teachers describe their experiences from Kindergarten through eighth grade, the highest grade level of their students. I hoped that they would then compare their timeline and narratives with their students so they could learn their students at a deeper level. 
Teachers collaborated to a high degree in the Educational History model, and teachers described their histories as a tapestry woven with the threads of their experiences; they surveyed their students to compare their histories with the histories of their students. Teachers using this model agreed that, “The influence of a good teacher can never be erased.”

\section{Overall Observations of Teachers toward Study Models}

In reflecting on all of the study models, teachers appreciated having a range of models to select from. Some gravitated toward linear options, while others enjoyed thinking flexibly. One teacher described that the democratic model helped him have a theoretical awareness, and that his other model, the SIOP model, gave him a comfortable and clear structure.

Teachers sought more explanation of study methods, and how they were developed. There was a curiosity about if these studies had been used elsewhere and to what effect. Teachers wanted to speak to the authors who wrote about these approaches initially, and if this application aligned to what they intended.

\section{The Role of Professional Learning Communities}

Most teacher participants had participated in professional learning community study sessions in years prior to this study. Because the school is an outer urban, high poverty minority majority school some teachers had explored issues of poverty, data analysis, and school improvement planning in professional learning sessions in the past. Some teachers had not worked together before because they work in different instructional areas or with different grade levels. The professional learning communities 
provided a structure for all of the participants. Perhaps pairs of teachers could have made study models work, but the safe environment, lesson and schedule of the sessions helped teachers anticipate what they needed to do. All teachers safeguarded the shared group norms throughout the study.

During the study sessions, teachers determined the topics for upcoming sessions, they negotiated dates for the meetings, and they explored White privilege, poverty, racism and resilience. Teachers modeled open-mindedness, whole heartedness, respect, intellectual responsibility and inclusive dialogue, making space for each participating teacher to add to the dialogic experience Teachers were vested in this work. They modeled open-mindedness, whole heartedness, and intellectual responsibility (Bohm, 1996; Dewey, 1944; Shields, 2003; Wheatley, 2002). In fact, they were curiously including all in an attempt to know more about themselves and each other. Participating teachers also examined their own values, beliefs and customs that were formerly unexamined. Before this study, the majority of teachers were unaware of the values and beliefs they bring to the classroom (Bartolome, 1996; Nieto, 2002). This selfidentification is a step that Zhao (2009) called for in the work of understanding others across cultures. In a few months of sessions and reflective dialogue, using models to examine their teaching, two consistent themes emerged: cross cultural proficiency, and student resilience (Robins et al., 2002). Because this deep reflection in an environment of trust was so meaningful, teachers mourned losing collaborative group time toward the end of the study. 
To replicate this model would require several factors: time for teachers to meet, a transformative collegial leader, professional learning community structures, and a high level of trust that will allow dialogue to happen. All of these factors lessen teacher isolation. Teachers often enter the school, teach all day, and then return home with papers to grade. Returning the next day, the isolating days go on for weeks and years. In their culmination presentations and in exit interviews, teachers reported a commitment to and benefit from dialogue. They took on the task that Shields (2003) urged:

It will be the task of each transformative leader...To create the norms of continuous dialogue - in the halls, in the staff room, at staff meetings, by disseminating articles, by a judicious comment or a strategically posed question in daily e-mail...The possibilities are endless. (p. 290)

An unanticipated outcome was the depth to which teachers connected with each other and with their students. Teaching generally is isolating and individualistic. Furthermore, teachers are responsible for all students. This can be difficult. Anyon (1997) lamented, "students whose home circumstances are extremely stressful...make many of them restless and confrontational; they can be difficult to teach, and to love” (p. 28). By working together as a group, sharing successes in engaging students, and learning from each other, there were many stories of students becoming engaged and improving their self-images.

This engagement may be in part from teachers learning about their own identities and the identities of their colleagues. As many authors purport, once their values are explicit, teachers can strengthen their care or students in sustainable ways (Fullan, 2005, Noddings, 1992; Nolan \& Hoover, 2004). It is exciting that these behaviors were evident throughout the study. Teachers practiced complex and differential views of learning, 
informed and reflective judgment, self-discovery and democratic principles in their work together.

\section{Merit Based Pay, Portfolios, Rubrics, Classroom Walk Abouts, and so Forth}

This study does not reject clinical evaluation models. In fact, rubrics or other tools that form a shared language we can use to reflect on improving teaching are valuable. However, I agree with Peterson (2000), who proposed that these models use a discrepancy-based view. The idea of most evaluative models is to measure where a person is, prove it by evidence and determine advancement, employment or feedback. Peterson (2000) further suggested that there is no agreed upon list of the attributes of effective teachers; different settings require different teaching; and teaching can be effective but look very different from one teacher to another. I believe that these models cannot be objective, even if they are designed to assure objectivity.

In fact, teacher evaluation is mostly sociological and political. It is political because teachers can lose their employment as a result of the evaluation process, or they can continue their employment. It is mired in contracts, with unions bargaining for working conditions and benefits of teachers.

Sociologically, teacher evaluation can be based on favoritism, or familiar views of what a good classroom looks like can lead to a favorable evaluation. Additionally, the teacher can put on a show for the visiting evaluator. Teacher observations capture surface level, visual information, and often are informed by checklists. Because so few resources are dedicated to wrangling with the difficult nuances of excellence or understanding the 
complexity that teachers face in the classroom, teacher evaluation is based on little information with even less time to reflect and discuss teaching in deep ways.

This study invited teachers to invest time and energy with their evaluator to reflect deeply about all aspects of the teaching and learning happening in their classrooms. It provided a time for collaboration and dialogue. Teachers attended the learning sessions without compensation, apart from eating a dinner provided to them. They are hungry to improve and passionate about their craft.

\section{What is a High Performing Teacher?}

Although emergent literature is beginning to describe high performing teachers as star teachers, gifted or exceptional (Lunenburg \& Ornstein, 2004), this study simply identified the teachers who qualify for multiple year goal setting, who participate in school improvement and other leadership efforts, and who have consistently received positive evaluations. The teachers in this study are primarily White, but they teach in high poverty, minority majority, outer urban, schools with students of high mobility. They

persevere day after day and year after year hoping to educate all students. While other teachers lament the changing demographics and use this change as an excuse, these teachers take stock of where they are and plan singly or with others to move forward for the benefit of students. Teachers wanted to continue the project, but also had other responsibilities that occupied their time and focus.

In fact, these teachers and others like them may not have been evaluated in many years; many consider teacher evaluation a non-event (Peterson, 2000). Because of limited resources, the principal must prioritize who he or she evaluates, and must evaluate 
struggling or non-performing teachers. High performers are the teachers that the principal knows well. The principal can go into his or her office, and write up a laudatory summative evaluation without pause and without following an observation protocol. No matter how many observations they could conduct, the observations merely yield surface level information. High performing teachers are more interested in nuances and beauty in their teaching; they have mastered surface level aspects of their teaching practice.

High performing teachers take on new tasks for the benefit of students and the school community. High performing teachers had other projects to complete apart from the study. Some of these included attending classes and completing homework, or taking the lead in an improvement effort within the school or district. Participating teachers wanted more time for deep engagement in sessions and to complete their projects. When not in a study session, they were extremely busy, and had a difficult time finding time.

Some schools and teachers are closing the achievement gap and are gaining national attention. This group of teachers has reviewed and learned about many models through the work of Daggett (2008). Many teachers are implementing new models in an attempt to improve school. The school improvement model is a familiar process to them. There have long been checklists and descriptions of steps schools must take to be excellent, model, or accelerated, but this study is focused at a deep level on improving the connections of teachers with their students within the classroom (Nieto, 2002).

Because teaching essentially happens within the classroom between the teacher and student, the teacher relies on student feedback as the most readily available source of information they can use (Darling-Hammond, 1997; Peterson, 2000). By helping teachers 
to examine their own belief systems while learning their students, I believe that teachers can view a breach between them and their students, and then seek a connection across difference with their students.

Data from the urban middle school in the study, regarding student negative discipline referrals and student achievement, show an inordinate rate of referrals for Black and Brown students, while the achievement of students from high to low is predictably Asian, White, Black and then Brown. In our outer urban schools of rapid demographic shifts, White teachers teach students of others. It is not always easy to love students, but if teachers can begin to love them, do their own inner work to learn their own belief systems and gain an awareness and value of difference, this forms the groundwork to grow the teacher belief that all students can learn. Democratic practice cannot happen in classrooms where all students are not included as integral learners or where teachers enact a banker's model of education (Freire, 1970) in which students receive information and are responsible for their own learning or lack thereof.

\section{The Role of Love in Teaching and Learning and in this Study}

"A whisper of love in the teacher's instruction can bring to school the reluctant student on a holiday” - Iranian saying.

Teachers described love as central to their practice. A love ethic encompasses care, commitment, trust, responsibility and respect in our daily interactions (hooks, 2000; Liston \& Garrison, 2004). Teachers did not feel sorry for their students. Rather than blame the students, they reported that it is their responsibility to provide a meaningful 
education for their students, to seek high engagement and to love their students. When teachers refer to love, they mean the love that Nieto (1999) described:

By "love" I do not mean a mawkish or sentimental demonstration of concern for students. Rather Love is at the core of good teaching, because it is predicated on high standards, rigorous demands and respect for their students, their identities and their families. (p. 100)

Teachers in the study committed to learn their own belief systems, began to seek justice and to learn that racism is alive, attempted to understand student identities and began to bridge the gaps of difference partly responsible for the achievement gap.

\section{Importance of a Collaborative Principal or Leader to Facilitate this Study}

Sid Nye, in a conversation with me confirmed the importance of the collaborative leader when he said:

I am emboldened by you. You have helped me maximize my potential and the potential of my students. I've become very encouraged about what I've been able to accomplish. I can find the flow described by Mihaly Csinkszentmihalyi. I don't realize what time it is or if am hungry when I am fully engaged in working with students, or planning my work.

The role of the principal is essential to this work. The principal must be a collaborative leader that engenders trust and creates a space for dialogue. The ability of teachers to determine the topics for the next lesson, to self evaluate and to talk openly are essential elements to the success or failure of this approach. This requires humility and invitation to explore ideas on the part of the principal.

Lending credence to the importance of leadership, Smith (1992) conducted a quantitative study of effective middle school teachers. Smith’s results identified, among other factors, the importance of a concerned, listening principal who knows how to take 
action, team compatibility and commitment and adequate planning time, and participatory choice and teacher involvement in staff development.

I am a critical educator, a collaborative leader and a person who works to increase my own cultural proficiency in specific ways. Although no person ever is fully culturally proficient, this is one of my central values. The importance of a leader who helps teachers know themselves and their students is described by Lindsey, Roberts and CambellJones (2005):

Leaders who manifest cultural proficiency guide their colleagues to examine personal values and behaviors in such a way that the members of the school realize that it is they who must adapt their practices to meet the needs of the students and the community they serve. (p. 53)

The initial design of this study included me as the principal and leader of the teachers facilitating the study. Due to leadership changes and my own changing role, I was not the principal of the teachers during the study. This could have been a positive or negative factor. It could have been positive because I could not evaluate the teachers. This could have also been a detractor, as teachers were not as motivated to complete their goal setting process and final study products, because they were not part of their ongoing required evaluation materials.

\section{Limitations and Roadblocks}

Because this was the first time this study was attempted, evident improvements are needed. The timeline for the study mirrored the September through February evaluation calendar. This was not enough time for teachers to complete their projects, and teachers wanted to continue working together. It would have been better to begin in September and continue to the end of the school year. 
In this iteration, teachers were not compensated for their time; nor were the facilitator or the guest speaker. The school already owned all presentation technology and needed supplies. Teachers met after their contract day ended, as I was not their principal, and I wanted to assure their time would not be called into question. The only cost of the study was the dinner cost that the researcher purchased, and copies of lesson materials as well as the copying of the handbook itself. In the future, these costs could be considerable, if teachers were afforded substitute time, for instance, or if the facilitator and guest speaker were compensated. Matthew spoke to the cost of this study as being justifiable and valuable, when he said, “What is the cost if we don't do this work? How much is it costing our students to have mediocre teachers?”

This study could have been derailed, if this study included marginal or novice teachers. Because the work included only high performers, there were not issues of protecting teacher rights by the union or retribution of the principal toward the teacher participants for working with their former principal. Of course, I interacted on several occasions to describe the study with the new principal, as well as to invite him to visit our sessions that were held in his library. Political realities must be negotiated to complete a study of this nature.

Most teachers did not complete the exit survey and goal setting forms, again because I was not the principal and because the timeline was too short. Teachers knew they would have to set goals with their new principal, and did not want to complete goal setting just for the heck of it. Also, the exit survey tool could have been more effective if tied to initial questions, and if it could elicit less redundant responses. 


\section{Future Implications}

For an initial field test of a handbook containing methods of reflection on the cutting edge of teacher evaluation, the results are encouraging, and call for replication of this process in the future. This problem based learning experience succeeded in having enough built in ambiguity so that teachers explored multiple solutions. Instead of looking for the external, simple and non-existent magic bullet, teachers looked within. Teachers learned just as their students do in their classrooms. They studied, applied themselves, reflected, collaborated with each other, learned about their students and took responsibility for student understanding or lack thereof and shared their discoveries (Darling-Hammond, 1997). Teachers talked about loving their students and began to love each other. One teacher said, “Of course, I love her. I want to know other teachers on our staff including their joys and heartaches so I can understand them better.”

Perhaps in its next iteration, a group of high performing teachers can begin to help us develop a clearer definition of high performing teachers and what they believe it would take to improve student resilience. Or, another group may explore a totally unanticipated area of the highly complex, compelling quest we call education.

Another option for the handbook and its models is to use the handbook with a group of principals. Building a professional learning community among the principals, it would be interesting to see if the principals would learn about their own identities and the identities of their colleagues. This option would necessitate a skilled facilitator, and would have to be given timelines and clear expectations to be possible. 
A collaborative principal leader may choose to try this model with his or her staff. The principal would need to listen intently to the teachers, who may limit their sharing with him or her because of the hierarchical positional difference between principals and teachers, whether or not the principal intended this to happen.

The human resources department could choose to allow teachers to choose a model from the handbook to reflect on their teaching over a three-year period. This is currently an option for high performing contract teachers. However, due to a lack of clarity or structure, teachers rarely choose these options, relying on the same traditional evaluation models participants in the study rejected. To build in a study partner, the human resources department could offer this to teacher pairs or teams.

If this teacher group or a subset of it choose to study for another year, they could invite in a facilitator, maybe even their own principal. Teachers could each invite one more teacher to form a new group, realign models or even try new models that they can discover and try out or develop for themselves. The principal, in this scenario, could allow teachers into the group regardless of their contract status, if approved by the human resources department and the union.

One improvement to the study could be to offer college credit. In this case, a facilitator from a local college or university could be hired to work with a group of teachers with or without their principal. The continuing education department or education department of a local university could approve the study. Then, teachers would consider it a class, receive a grade, record continuing professional development hours and perhaps consistently complete all requirements. 
The tools in the handbook, and the handbook itself could benefit teachers at all stages of professional development and experience. If a trained team of teachers could be partnered with new, mediocre or struggling teachers in a professional learning community structure, it could help both partners. In this case, teachers would apply to be part of the study, and the principal and district office would have to approve the participation of teachers included in the year-long study.

For future teachers to all engage fully in this kind of an approach, they must have choice and be able to shape the experience. This requires a facilitator who is collaborative and who can stay in the role of responding to teacher curiosity and thirst for specific knowledge.

Although not anticipated, the attributes of resilience and methods of teaching resilience as a way to help close the achievement gap in challenging schools could be an area for further exploration. To conduct another study would help clarify the processes, and could further explore the evolution of the next generation of transformative teacher evaluation models.

In a different school setting, different questions or models may be more appropriate to their school or district challenges. This handbook was specifically developed to help one middle school that has experienced rapid and extreme demographic shifts in a short period of time. The school is an underperforming, minority majority, high poverty, high mobility school. This phenomenon is happening outside of other cities whose central areas are gentrifying. Truck farms in our Northwest school 
have been replaced by low income and affordable housing. That trend alone has brought new families seeking housing to our area.

Another possible next step would be to continue the study with the same group, but to add the work regarding outcomes students experience and student work produced. What would happen if all teachers set high goals for students, and the group worked supportively to realize those goals? How would their planning change? Would they learn to model and teach perseverance or resilience?

\section{Conclusion}

As a result of these positive outcomes, I believe that this approach to teacher self reflection and evaluation can improve teachers, schools and students. Exploring teacher evaluation as a shared practice situated in professional learning communities is a democratic next step for critical educators transforming school. This study confirms that teacher evaluation can support professional growth and school improvement for consummate teachers who constantly hone their teaching craft.

Teacher participants changed their current and future practice. Teachers began to talk about loving their students, and knowing and loving each other in new ways. Teachers reveled in the creativity and community they experienced. As one teacher termed it, "This study helped me reenergize and thrive in a very difficult time of immense change and challenge.”

The focus on high performing teachers, and the work to help them excel may help teachers move from high performing or star teachers (Ripley, 2010) to superb. I believe, as does Darling-Hammond (1997), that improving the qualities and commitment of 
teachers is the surest way to improve education for all students. High performing teachers explored problems from many perspectives, generated many alternative plans, and chose a plan for themselves (Glickman, 2002). What can teachers honing their skills at a level of high sophistication accomplish that we cannot anticipate?

“Teaching is demanding...it demands a long journey” (Tremmel, 1993, p. 106). It was beautiful to see teachers paired up to study in a communal way, in keeping with the ancient Jewish tradition of hevrutah, which means study in pairs. Every high performing teacher in this group is a disciplined, driven, passionate practitioner. They discussed even the most uncomfortable, often untouchable ideas in our society such as race, class, and love. Martha Bauridel shared her commitment to love her colleagues and to act in hevrutah when she wrote,

I try to allow myself to be myself when I present to and talk with staff. I think that an important way to stimulate and spark others is to listen empathetically and really hear what others say: what are their beliefs concerns and delights... I can provide the support teachers need to be the best they can be. Teachers often make amazing discoveries when they have someone with whom to talk things out.

Martha is ready to make herself fully vulnerable to her students and her colleagues, with the goal of improving school for all. She regularly acts lovingly and passionately in her work environment.

I believe that teachers began to believe all students can learn (Nieto, 2002). This is a first step that must be taken before we as educators can realize a high quality education for all students not dependent on where they live or who they are. Marie and other teachers discovered that by looking at their students as students of potential, they were able to support and understand their student in new ways. 
Instead of trying to contain the enthusiasm of her African American students who were learning to read using Green Eggs and Ham, Marie celebrated them. Marie said, “All of sudden, my students turned Green Eggs and Ham in to a rap and danced along to the rap. They used their creativity and culture beautifully. There was space for that expression in my class.” Instead of stopping her students or making them be quiet, Marie opened the curtain so that they could perform for an adjacent middle school classroom. She celebrated a reality much different from her own.

Teachers in the study continually explored their own identities and the identities and realities of their students. This is one of the attributes of critical thinking called for in transformative evaluation and in cultural proficiency literature. In effect, teachers jumped out of the water, as Marion Reliant illustrated, using a familiar aphorism:

A fish doesn't know its wet because he is always in the water. We get lost in our surroundings. We forget that everything is contextual. We become happily blind and content. We become the fish that doesn't know it is wet. We need to stretch what we know and don't know. What is the story of success? All survivors have a powerful story that they tell over and over. It motivates them and others. We all have our narratives. In our teaching, we have to teach ourselves and our students that we write our own narrative, and that our narratives are in context. We need to take risks. We cannot become bottom feeders. We have to jump out of the water, take risks and teach our students, our colleagues and ourselves. The relevance and impact of narrative and context is immense.

Teachers constantly stretched themselves and each other, in caring, critical, reflective ways.

What strikes me is how much I learned, and loved the teachers in the study. A colleague referred me to the cultural therapy work of Spindler and Spindler (1994). While the Spindlers used case studies in cultural therapy, my approach appears to be devising a 
structure so that informative case studies can emerge from the experiences of teachers and students. In 1994, the Spindlers wrote:

We are reaping the harvest of our own history, and we are making efforts to change it, but not fast enough, not thoroughly enough, not deep enough in our own psyches. There are very few consciously racist teachers but there are many teachers, perhaps even all teachers, who have very strong biases that are quite unmovable because they are integrated in their own sense of identity and self - in many cases, the enduring self. (p. 23)

Considering that the Spindlers were working far earlier than myself in the field, I wonder how far we have come and how far we have yet to go. How long will it take? Perhaps this work extends beyond teacher evaluation to the every day interaction of us all - one to another.

High performing teachers can create an inclusive, beautiful education for all. It is imperative that we learn from teachers in this study. We must never be done improving ourselves or school. Our students do not have time to wait. If they are in eighth grade, this is the only eighth grade they have. They are worth it and we are worth it.

We must urgently and completely commit to improving our education system, educators and ourselves. Students need us to love tirelessly without giving up - on them or on ourselves. We must tirelessly and relentlessly strive for improvement and passionate practice with the hope of a better reality - a beautiful, robust, classy education for all students.

Freire (1998b) urged me on in this quest to be courageous, to nurture excellence of myself and others and to critically continue to lead within the difficult environment of education when he wrote: 
We must dare, in the full sense of the word, to speak of love without the fear of being called ridiculous, mawkish, or unscientific. If not antiscientific. We must dare in order to say scientifically, and not as mere blah, blah, blah, that we study, we learn, we teach, we know with our entire body. We do all of these things with feeling, with emotion, with wishes, with fear, with doubts, with passion, and also with critical reasoning. However, we never study, learn, teach or know with the last only. We must dare so as never to dichotomize cognition and emotion. We must dare so that we can continue to teach for a long time under conditions that we know well: low salaries, lack of respect, and the ever-present risk of becoming prey to cynicism. We must dare to learn how to dare in order to say no to the bureaucratization of the mind to which we are exposed every day. We must dare so that we can continue to do so even when it is so much more materially advantageous to stop daring. (p. 3)

Any future steps we take as engaged, critical transformative educators will take us closer to realizing a loving, beautiful, truly democratic public education for all of our students regardless of where they were born, who they are or where they live. Today's educated students are crucial to our ongoing democratic society (Giroux \& Giroux, 2004). To do anything less than to teach all students well is to contribute to the same deeply-rutted path minority and poor children that limits their choices and ability to participate in deep democracy. 


\section{REFERENCES}

Acheson, K. A., \& Gall, M. D. (2003). Clinical supervision and teacher development: Preservice and inservice applications ( $5^{\text {th }}$ ed.). New York, NY: John Wiley \& Sons.

Adams, J. D., \& Kirst, M. (1999). New demands and concepts for educational accountability: Striving for results in an era of excellence. In J. Murphy \& K. S. Louis (Eds.), Handbook of research on educational administration ( ${ }^{\text {nd }}$ ed.; pp. 463-489). San Francisco, CA: Jossey-Bass.

Anderson, G. L. (2002). Reflecting on research for doctoral students in education. Educational Researcher, 31(7), 22-25.

Anyon, J. (1997). Ghetto schooling: A political economy of urban educational reform. New York, NY: Teachers College Press.

Apple, M., \& Beane, J. (1995). Democratic schools. Alexandria, VA: Association for Supervision and Curriculum Development.

Bartolome, L. (1996). Beyond the methods fetish: Toward a humanizing pedagogy. In P. Leistyna, A. Woodrum, \& S. Sherblom (Eds.), Breaking free: The transformative power of critical pedagogy (pp. 229-252). Cambridge, MA: Harvard Educational Review.

Bateson, M. C. (1994). Peripheral visions: Learning along the way. New York, NY: HarperCollins.

Bergmann, H., Hurson, K., \& Russ-Eft, D. (1999). Everyone a leader. New York, NY: John Wiley \& Sons.

Blankstein, A. M. (2004). Failure is not an option: Six principles that guide student achievement in high-performing schools. Thousand Oaks, CA: Corwin Press.

Blumberg, A., \& Greenfield, W. (1980). The effective principal: Perspectives on school leadership. Boston: Allyn \& Bacon.

Bogdan, R. C., \& Biklen, S. (2003). Qualitative research for education $\left(4^{\text {th }}\right.$ Ed). Boston: Allyn \& Bacon. 
Bohm, D. (1996). On dialogue. London: Routledge Press.

Bolman, L. G.., \& Deal, T. E. (1997). Reframing organizations: Artistry, choice and leadership. San Francisco, CA: Jossey-Bass.

Bridges, E. M., \& Hallinger, P. (1995). Problem-based learning in leadership development. Eugene, OR: ERIC Clearinghouse on Educational Management. (ERIC/CEM Accession No. EA 026 366)

Chenoweth, T. C., \& Everhart, R. B. (2002). Navigating comprehensive school change: A guide for the perplexed. Larchmont, NY: Eye on Education.

Chronicle News Service. (2008, March 2). A third of public school students lives in poverty. Muskegon Chronicle. Retrieved from http://blog.mlive.com/chronicle/ 2008/03/a_third_of_public_school_stude.html

Costa, A. L., \& Kallick, B. (2000a). Habits of mind: Activating and engaging. Alexandria VA: Association for Supervision and Curriculum Development.

Costa, A. L., \& Kallick, B. (2000b). Habits of mind: Assessing and reporting. Alexandria VA: Association for Supervision and Curriculum Development.

Costa, A. L., \& Kallick, B. (2000c). Habits of mind: Discovering and exploring. Alexandria VA: Association for Supervision and Curriculum Development.

Costa, A. L., \& Kallick, B. (2000d). Habits of mind: Integrating and Sustaining. Alexandria VA: Association for Supervision and Curriculum Development.

Cotton, K. (2000). The schooling practices that matter most. Portland OR: Northwest Regional Education Laboratory, and Alexandria, VA: Association for Supervision and Curriculum Development.

Cox, D. A. (2004). Leaders fostering resilience in schools (Doctoral dissertation). Pittsburgh, PA: University of Pittsburgh.

Creemers, B. P. M. (1994). The effective classroom. New York, NY: Cassell.

Cresswell, J. W. (2005). Educational research: Planning, conducting, and evaluating quantitative and qualitative research. Upper Saddle River, NJ: Pearson, Merrill Prentice Hall.

Daggett, W. (2008). Rigor and relevance from concept to reality. Rexford, NY: International Center for Leadership in Education. 
Danielewicz, J. (2001). Teaching selves: Identity, pedagogy, and teacher education. Albany, NY: State University of New York Press.

Danielson, C. (2002). Enhancing student achievement: A framework for school improvement. Alexandria, VA: Association for Supervision and Curriculum Development.

Darling-Hammond, L. (1997). The right to learn: A blueprint for creating schools that work. San Francisco, CA: Jossey Bass.

Darling-Hammond, L. (2002). Learning to teach for social justice. New York, NY: Teachers College Press.

Delpit, L. (Ed.). (2002). The skin that we speak: Thoughts on language and culture in the classroom. New York, NY: The New Press.

Dewey, J. (1944). Democracy and education. New York, NY: The Free Press.

Downey, C., Steffy, B., English, F., Fraise, L., \& Poston, W. (2004). The three-minute classroom walk-through: Changing school supervisory practice one teacher at a time. Thousand Oaks, CA: The Corwin Press.

Dufour, R., \& Eaker, R. (1998). Professional learning communities at work: Best practices for enhancing student achievement. Bloomington, IN: National Educational Service.

Duffy, F. M. (1998). The ideology of supervision. In G. R. Firth \& E. F. Pajak (Eds.), Handbook of research on school supervision (pp. 181-199). New York, NY: Simon Schuster \& Macmillan.

Duke, D. (Ed.). (1995). Teacher evaluation policy: From accountability to professional development. Albany, NY: State University of New York Press.

Farahmandpur, R. (2003). Preface to McLaren, P. Life in schools: An introduction to critical pedagogy in the foundations of education. Boston: Pearson Education.

Foster, W. (1986). Paradigms and promised: New approaches to educational administration. Amherst, NY: Prometheus Books.

Freire, P. (1970). Pedagogy of the oppressed. New York, NY: Herder and Herder.

Freire, P. (1973). Education for critical consciousness. New York, NY: Continuum. 
Freire, P. (1998a). Pedagogy of freedom: Ethics, democracy and civic courage. Lanham, MD: Bowman \& Littlefield.

Freire, P. (1998b). Teachers as cultural workers: Letters to those who dare teach. Boulder, CO: Westview Press.

Fry, R. (2009). The rapid growth and changing complexion of suburban public schools. Pew Hispanic Center. Pew Research Center Publications. Retrieved from: http://pewhispanic.org

Fullan, M. (2005). Leadership and sustainability: System thinkers in action. Thousand Oaks, CA: Corwin Press.

Gardner, H. (1999). The disciplined mind: What all students should understand. New York, NY: Simon \& Schuster.

Giroux, H., \& Giroux, S. S. (2004). Take back higher education: Race youth and the crisis of democracy in the post-civil rights era. New York, NY: Palgrave Macmillan.

Glickman, C. D. (2002). Leadership for learning: How to help teachers succeed. Alexandria, VA: Association for Supervision and Curriculum Development.

Glickman, C. D., \& Kanawati, D. G. (1998). Future directions for school supervision. In G. R. Firth \& E. F. Pajak (Eds.), Handbook of research on school supervision (pp. 1248-1257). New York, NY: Simon Schuster \& Macmillan.

Goals 2000: Educate America Act, Pub. L. No. 109-227, 103d Cong. 108 Stat. 125-280 (1994).

Good, T., \& Brophy, J. (2000). Looking into classrooms (8 ${ }^{\text {th }}$ ed.). New York, NY: Addison, Wesley \& Longman.

Greenfield, W. D., Jr. (1990, October). Five standards of good practice for the ethical administrator. The NASSP Bulletin, 74(528), 32-37.

Greenfield, W. D., Jr. (2004, April 11-16). Connecting value leadership, normative change and school improvement [Abstract]. Proceedings of the annual meeting of the American Educational Research Association, San Diego, CA.

Gregory, A., \& Weinstein, R. (2008, August). The discipline gap and African Americans: Defiance or cooperation in the high school classroom. Journal of School Psychology, 46(4), 455-475. 
Harris, B. M. (1998). Paradigms and parameters of supervision in education. In G. R. Firth \& E. F. Pajak (Eds.), Handbook of research on school supervision (pp. 1-37). New York, NY: Simon Schuster \& Macmillan.

Heisinger, D. A. (1994). Factors that motivate Washington state teachers to participate in professional growth and development (Doctoral dissertation, Portland State University, 1994).

hooks, b. (2000). All about love: New visions. New York, NY: Harper Collins.

hooks, b. (2003). Teaching community: A pedagogy of hope. New York, NY: Routledge.

Howard, G. R. (1999). We can't teach what we don't know: White teachers, multiracial school. New York, NY: Teachers College Press.

Iwanicki, E. (1990). Teacher evaluation for school improvement. In J. Millan \& L. Darling-Hammond (Eds.), The new handbook of teacher evaluation; Assessing elementary and secondary school teachers (pp. 158-176). Newbury Park, CA: Sage Publications.

Iwanicki, E. (1998). Evaluation in supervision. In G. R. Firth \& E. F. Pajak (Eds.), Handbook of research on school supervision (pp. 138-175). New York, NY: Simon Schuster \& Macmillan.

Kauchak, D., Peterson, K., \& Driscoll, A. (1985). An interview study of teachers' attitudes toward teacher evaluation practices. Journal of Research and Development in Education, 19(1), 32-37.

Knowles, M. (1984). The adult learner: A neglected species ( $3^{\text {rd }}$ ed.). Houston, TX: Gulf Publishing.

Ladson-Billings, G., \& Tate, F. F. (1995, Fall). Toward a critical race theory of education. Teachers College Record, 97(1), 47-68.

Lambert, L. (1998). Building leadership capacity in schools. Alexandria, VA: Association for Supervision and Curriculum Development.

Lindsey, R., Roberts, L., \& CambellJones, F. (2005). The culturally proficient school: An implementation guide for school leaders. Thousand Oaks CA: Corwin Press.

Liston, D., \& Garrison, J. (Eds.). (2004). Teaching, learning and loving: Reclaiming passion in educational practice. New York, NY: RoutledgeFalmer. 
Littky, D.,\& Grabelle, S. (2004). The big picture: Education is everyone's business. Alexandria VA: Association for Supervision and Curriculum Development.

Lunenburg, F., \& Ornstein, A. (2004). Educational administration: Concepts and practices $\left(4^{\text {th }}\right.$ ed.). Belmont, CA: Wadsworth/Thompson Learning.

Macintosh, P. (1988). White privilege and male privilege: A personal account of coming to see correspondences through work in women's studies. Wellesley MA: Wellesley College Center for Research on Women.

Marzano, R., Pickering, D., \& Pollock, J. (2001). Classroom instruction that works. Alexandria, VA: Association for Supervision and Curriculum Development.

Melton, K. (2006, April 23). In east county, a cultural shift: African American families flow in, bringing adjustments for schools and the new students. The Oregonian. Retrieved October 15, 2006 from OregonLive.com

McLaren, P. (2003). Life in schools: An introduction to critical pedagogy in the foundations of education. Boston, MA: Pearson Education.

Neville, R. F., \& Garman, N. B. (1998). The philosophical perspective of supervision. In G. R. Firth \& E. F. Pajak (Eds.). Handbook of research on school supervision (pp. 200, 229-241). New York, NY: Simon Schuster \& Macmillan.

Nieto, S. (1999). The light in their eyes: Creating multicultural learning. New York, NY: Teachers College Press.

Nieto, S. (2002). Language, culture, and teaching: Critical perspectives for a new century. Mahwah, NJ: Lawrence, Erlbaum Associates.

Nieto, S. (2003). What keeps teachers going? New York, NY: Teachers College Press.

No Child Left Behind Act of 2001, Pub. L. No. 107-110 (2002) (enacted).

Noddings, N. (1992). The challenge to care in schools: An alternative approach to education. New York, NY: Teachers College Press.

Nolan, J., \& Hoover, L. (2004). Teacher supervision and evaluation: Theory into practice. Hoboken, NJ: John Wiley \& Sons.

Orfield, G. (2001). Schools more separate: Consequences of a decade of resegregation. Cambridge, MA: Harvard University. Retrieved from http://www. civilrightsproject.ucla.edu/research/deseg/separate_schools01.php 
Pajak, E. (2000). Approaches to clinical supervision ( $2^{\text {nd }}$ ed.). Norwood, MA:

Christopher-Gordon.

Palmer, P. (1997). The courage to teach: Exploring the inner landscape of a teacher's life. San Francisco, CA: Jossey-Bass.

Palmer, P. (1997, November/December). The heart of a teacher: Identity and integrity in teaching. Change Magazine, 29(6), 14-21.

Payne, R. (1996). A framework for understanding poverty ( $3^{\text {rd }}$ rev.). Highlands, TX: Aha! Process.

Peterson, K. (2000). Teacher evaluation: A comprehensive guide to new directions and practices ( $2^{\text {nd }}$ ed.). Thousand Oaks, CA: Corwin Press.

Peterson, K., \& Chenoweth, T. (1992, December). School teachers' control and involvement in their own evaluation. Journal of Personnel Evaluation in Education, 6(2), 177-190.

Peterson, K., Kelly, P., \& Caskey, M. (2002). Ethical considerations for teachers in the evaluation of other teachers. Journal of Personnel Evaluation in Education, 16(4), 317-324.

Peterson, K., \& Peterson, C. (2006). Effective teacher evaluation: A guide for principals. Thousand Oaks, CA: Corwin Press.

Ribas, W. (2002). Teacher evaluation that works: The educational, legal, public relations and social-emotional standards and processes of effective supervision and evaluation. Westwood, MA: Ribas Publication.

Ripley, A. (2010, January/February). What makes a good teacher? The Atlantic Online. Retrieved from http://www.theatlantic.com/magazine

Robins, K. N., Lindsey, R.B., Lindsey, D. B., \& Terrell, R. D. (2002). Culturally proficient instruction: A guide for people who teach. Thousand Oaks, CA: Corwin Press.

Salowe, A., \& Lessinger, L. (2001). Healing public schools: The winning prescription to cure their chronic illness. Lanham, MD: Scarecrow Press.

Samaras, A., \& Freese, A. (2006). Self-study of teaching practices. New York: NY: Peter Lang. 
Saphier, J. (1993). How to make supervision and evaluation really work: Supervision and evaluation in the context of strengthening school culture. Carlisle, MA: Research for Better Teaching.

Schwartz, E. (2001). Bal tashchit: A Jewish environmental precept. In M. D. Yaffe (Ed.), Judaism and environmental ethics (pp. 230-249). Lanham, MD: Lexington Books.

Senge, P. (2000). Give me a lever long enough... and single-handed I can move the world. In The Jossey-Bass reader on educational leadership (pp. 13-25). San Francisco, CA: Jossey Bass.

Sergiovanni, T. J. (1995). The principalship: A reflective practice perspective. Boston: Allyn and Bacon.

Shields, C. (2003). Good intentions are not enough: Transforming leadership for communities of difference. Lanham, MD: Scarecrow Press.

Short, P., \& Greer, J. (2002). Leadership in empowered schools: Themes from innovative effort. Upper Saddle River, NJ: Merrill Prentice Hall.

Sleeter, C. (2001). Preparing teachers for culturally diverse schools: Research and the overwhelming presence of whiteness. Journal of Teacher Education, 52(2), 94-106.

Smith, J. (1992). Effective middle school teaching: Factors that promote and maintain it (Doctoral dissertation, Portland State University).

Smith, W., \& Andrews, R. (1989). Instructional Leadership: How principals make a difference. Alexandria, VA: Association for Supervision and Curriculum Development.

Spindler, G., \& Spindler, L. (1994). Pathways to cultural awareness: Cultural therapy with teachers and students. Thousand Oaks, CA: Corwin Press.

Starratt, R. J., \& Howells, M. L. (1998). Supervision as moral agency. In G. R. Firth \& E. F. Pajak (Eds.), Handbook of research on school supervision (pp. 987-1005). New York, NY: Simon Schuster \& Macmillan.

Stillwell, D. (2003). Trust as a systemic structure in our organization. The Systems Thinker, 14(2), 2-6. Retrieved from http://www.pegasuscom.com

Stronge, J. H., \& Tucker, P. D. (2003). Handbook on teacher evaluation: Assessing and improving performance. Larchmont, NY: Eye on Education. 
Systems Thinking and Dynamic Modeling Project. (2002). Iceberg analysis worksheet. Portland, OR: The Waters Foundation.

Tremmel, R. (1993, Winter). Zen and the art of reflective practice in teacher education. In Harvard Educational Review, 63(4), 87-109.

Tucker, P., \& Stronge, J. (2005). Linking teacher evaluation and student learning. Alexandria VA: Association for Supervision and Curriculum Development.

Wheatley, M. J. (2002). Turning to one another: Simple conversations to restore hope to the future. San Francisco, CA: Berbett-Koehler Publishers.

White, E. C. (2004). Alice Walker. New York, NY: W. W. Norton \& Company.

Wink, J., \& Wink, D. (2004). Teaching passionately: What's love got to do with it? Boston: Pearson Education.

Wood, C. (1998). Human dimensions of supervision. In G. R. Firth \& E. F. Pajak (Eds.), Handbook of research on school supervision (pp. 1085-1103). New York, NY: Simon Schuster \& Macmillan.

Zhao, Y. (2009). Catching up or leading the way: American education in the age of globalization. Alexandria, VA: Association for Supervision and Curriculum Development. 
APPENDIX A

SELF EVALUATION HANDBOOK FOR HIGH

PERFORMING TEACHERS 


\section{TEACHER EVALUATION HANDBOOK: SELF EVALUATION FOR HIGH PERFORMING TEACHERS}

This handbook offers high performing teachers several options to use in reflection and improvement of their own teaching, while meeting summative evaluation requirements. These high performing teachers are teacher leaders who are involved in school improvement. They qualify for multiple-year goal setting. The study options give structure to self-study, and help teachers connect with traditionally underperforming students. Several options help teachers reflect on their identities, learn about their own practice, understand student identities, and measure outcomes.

"When all is said and done, what matters most for students' learning are the commitments and capacities of their teachers"(Darling-Hammond, 1997, p. 293).

Transformative Teacher Evaluation:

High Performing Teachers Conduct Self Evaluation

April 26, 2010

By: $\quad$ Carla Sosanya-Tellez

Portland State University 


\section{TEACHER SELF-EVALUATION HANDBOOK}

TABLE OF CONTENTS

$\begin{array}{ll}\text { Title and Abstract } & 1\end{array}$

Table of Contents 2

Core beliefs 3

Introduction 4

Glossary of terms 9

$\begin{array}{ll}\text { Group Norms } & 12\end{array}$

$\begin{array}{ll}\text { Timeline } & 13\end{array}$

$\begin{array}{ll}\text { Initial Self Survey } & 15\end{array}$

$\begin{array}{ll}\text { Study Options } & 16\end{array}$

Transformative Options

Option 1: The Iceberg Model 18

Option 2: Mind's Eye Model 23

Option 3: Democratic School Attributes 25

Option 4: Spiral Model of Continuous Improvement 26

Option 5: Student Questionnaires 28

Option 6: Community and Home Visits 31

Option 7: Structured Instruction Observation Protocol (SIOP) 33

Option 8: Educational History 35

Quick Write for Self Evaluation Learning Session 36

$\begin{array}{ll}\text { Exit Self Survey } & 37\end{array}$

Goal Setting Process and Form 38

$\begin{array}{ll}\text { Exit Interview Questions } & 40\end{array}$ 


\section{CORE BELIEFS}

Excellent public education is our goal.

Trust and confidentiality are essential.

Democracy is impossible without a literate populace.

All students deserve a beautiful education.

Love is central to all education.

Teachers are committed professionals.

Teachers reflect and think of problems from many perspectives.

All students can learn.

Optimism - teachers strive for what can be.

The commitment and abilities of their teachers predict student ability.

Passion and fun are essential elements in the classroom setting.

High performing teachers are open to change.

(Sosanya-Tellez 2009)
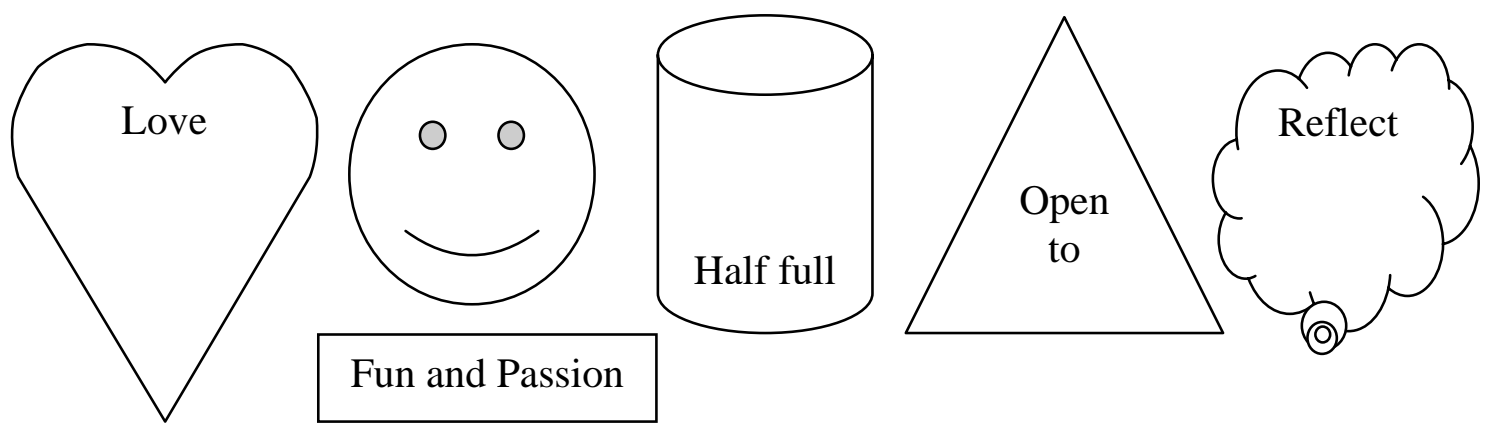


\section{HANDBOOK FOR TEACHER SELF-EVALUATION}

\section{INTRODUCTION:}

Ten teachers have completed a pilot project using this handbook. Their input has shaped this handbook, just as future teachers who use these study models will also change the handbook. With each iteration, models, processes and resources should become more articulated.

High performing teachers who use this handbook will take stock of their current practice, use tools to reflect on their teaching, and recalibrate their teaching to improve student outcomes. Teaching is a passion for high-performing teachers. Internally motivated, they are excited to learn all they can about their subject matter and school improvement for all students. Many of these teachers are teacher leaders who lead wholeschool improvement sessions. Traditional evaluation often holds little meaning for these exceptional teachers; they are often not evaluated regularly. Sometimes they are not evaluated at all.

In traditional clinical evaluation, teachers sit with their administrator to set goals, pre conference about upcoming observations and the evaluation process, are observed by the evaluator, meet to debrief the observations, and then meet for a summative evaluation conference. This approach assures due process, works well with novice or struggling teachers, but is not meaningful for high performing teachers. This work furthers ideas of many researchers (Wood, Pajak, Starrat \& Howells) who call for moving beyond traditional clinical evaluation to relational or transformative evaluation. Transformative evaluation moves teachers central to their own evaluation and considers critical issues. 
Teachers using this self-study method will:

Maintain a journal during the seven-month study period

Choose two study models to use to guide their reflection

Choose a study method with a partner for sharing and support

Examine issues of race, culture, and class

Provide feedback in the process to further explore transformative evaluation

Schedule regular monthly study sessions with others

Work with a facilitator for coordination and support

Present their work during the study period in a culmination event

This model considers issues of identity, poverty and democracy. As schools

experience increasing poverty and diversity within their student bodies, critical

evaluation to focus on these issues is essential for teachers and whole school

improvement. This work considers the family of evaluation approaches described by

Pajak (2000) as developmental or reflective. As Pajak described:

These models are sensitive to individual differences and the organizational social, political, and cultural contexts of teaching... (they) call for supervisors to encourage reflection and introspection among teachers in order to foster professional growth, discover context-specific principles of practice, and promote justice and equity. (p. 280)

When I was a teacher, I would have welcomed taking control of my own evaluation. In fact, growth I made in my practice resulted from my own commitment to improve. I also grew from observing and working with other teachers more than from clinical traditional evaluation. 
Pajak’s (2000) representation comparing established and emerging practices

provides another depiction of how aspects of teaching and learning are viewed:

\section{Moving to Emerging Practices}

\begin{tabular}{|c|c|c|}
\hline & Established Practice & Emerging Practice \\
\hline View of Learning & $\begin{array}{l}\text { Predictable, standard procedures } \\
\text { and outcomes }\end{array}$ & Complex and differential \\
\hline View of Teaching & $\begin{array}{l}\text { Mastering simple effective } \\
\text { routine behaviors }\end{array}$ & $\begin{array}{l}\text { Exercising informed reflective } \\
\text { judgment }\end{array}$ \\
\hline View of Supervision & $\begin{array}{l}\text { Reinforcing prescribed teacher } \\
\text { behaviors and skills }\end{array}$ & $\begin{array}{l}\text { Helping teachers discover and } \\
\text { construct professional knowledge } \\
\text { and skill }\end{array}$ \\
\hline View of Professional Knowledge & $\begin{array}{l}\text { General teaching methods context } \\
\text { and content free }\end{array}$ & $\begin{array}{l}\text { Practice is dependent on context, } \\
\text { subject and responsive to } \\
\text { individuals }\end{array}$ \\
\hline $\begin{array}{l}\text { View of Teachers and } \\
\text { Supervisors }\end{array}$ & $\begin{array}{l}\text { Isolated and independent } \\
\text { technicians }\end{array}$ & $\begin{array}{l}\text { Collegial team members, mentors } \\
\text { and peer coaches }\end{array}$ \\
\hline View of Schools & $\begin{array}{l}\text { Bureaucratic teaching } \\
\text { organizations }\end{array}$ & $\begin{array}{l}\text { Democratic teaching and learning } \\
\text { communities }\end{array}$ \\
\hline
\end{tabular}

Another source that calls for new directions in teacher evaluation is Peterson

(2000); this study examines many of the attributes he described. This study concentrates

heavily on moving the teacher to the center of evaluation and capturing good teaching.

The 12 new directions that Peterson called for are:

1. Emphasize, seek out, document and acknowledge good teaching

2. Use good reasons to evaluate

3. Place the teacher at the center of evaluation activity

4. Use more than one person to judge teacher quality and performance

5. Limit administrator role of judgment

6. Use multiple data sources

7. When possible, include actual pupil performance data

8. Use variable data sources to inform judgments

9. Spend time and resources to recognize good teaching

10. Use research on teacher evaluation correctly

11. Attend to sociology of teacher evaluation

12. Use results to encourage and form professional dossiers, publicize aggregated results, and support teacher promotion systems

I believe that high performing teachers are capable of complex self-analysis leading to

the realization of democratic, beautiful school for all. 
This chart outlines timelines, and purposes of a 7 month cycle of study activities:

\begin{tabular}{|c|c|}
\hline Teacher Steps and Timeline & Purpose of Each Step and Timeline \\
\hline $\begin{array}{l}\text { Receive invitation to participate } \\
\text { Attend orientation session } \\
\text { Receive materials } \\
\text { Begin personal journal } \\
\text { Complete Initial Self Survey } \\
\text { Select two study options } \\
\text { Identify at least one other teacher using the } \\
\text { same options }\end{array}$ & $\begin{array}{l}\text { Mid September } \\
\text { Fully understand steps in the study } \\
\text { Receive resource materials } \\
\text { This process is designed to fully inform each } \\
\text { teacher about what he or she will commit to do } \\
\text { and provides the opportunity to answer } \\
\text { questions at the beginning of the study. } \\
1^{\text {st }} \text { feedback forms completed }\end{array}$ \\
\hline $\begin{array}{l}\text { Read materials for learning session } \\
\text { Attend learning session } \\
\text { Share with other teachers progress or } \\
\text { challenges experienced in the study } \\
\text { Review Journal entries }\end{array}$ & $\begin{array}{l}\text { October } \\
\text { Explore culturally responsive teaching } \\
\text { Receive feedback and help from others } \\
\text { Share updates on self study progress/questions } \\
\text { Homework: White Privilege materials } \\
2^{\text {nd }} \text { set of feedback forms completed }\end{array}$ \\
\hline $\begin{array}{l}\text { Watch video clips or share readings } \\
\text { Engage in dialogue } \\
\text { Share with other teachers progress or } \\
\text { challenges experienced in the study } \\
\text { Review Journal entries }\end{array}$ & $\begin{array}{l}\text { November } \\
\text { Explore culturally responsive practices } \\
\text { Share updates on self study progress/questions } \\
\text { Homework: resilience information } \\
3^{\text {rd }} \text { set of feedback forms completed }\end{array}$ \\
\hline $\begin{array}{l}\text { Prepare for study session } \\
\text { Guest speaker } \\
\text { Share identities as a group } \\
\text { Reflect on study progress } \\
\text { Review journal entries } \\
\end{array}$ & $\begin{array}{l}\text { December } \\
\text { Explore identities and how they affect the } \\
\text { classroom for teachers and students } \\
\text { Share updates on self study progress/questions } \\
\text { Homework: Poverty information } \\
4^{\text {th }} \text { set of feedback forms completed } \\
\end{array}$ \\
\hline $\begin{array}{l}\text { Explore issues of social class } \\
\text { Work on study models } \\
\text { Review journal entries }\end{array}$ & $\begin{array}{l}\text { January } \\
\text { Explore how social class affects the classroom } \\
\text { for teachers and students } \\
\text { Prepare for culmination presentation } \\
\text { Share updates on self study progress/questions } \\
5^{\text {th }} \text { set of feedback forms completed }\end{array}$ \\
\hline $\begin{array}{l}\text { Participate in Culmination Gathering. } \\
\text { Share learning experiences with the group } \\
\text { Optional individual interview } \\
\text { Conduct exit self evaluation form }\end{array}$ & $\begin{array}{l}\text { February } \\
\text { Exhibit and celebrate learning during the study } \\
\text { Share any concerns or difficulties } \\
\text { Share suggestions for improvement } \\
\text { Share updates on self study progress/questions } \\
\text { Last set of feedback forms completed }\end{array}$ \\
\hline $\begin{array}{l}\text { Second set of Culmination Presentations } \\
\text { Goal Setting } \\
\text { Exit self evaluation completion }\end{array}$ & $\begin{array}{l}\text { March } \\
\text { Turn in all study models and presentation } \\
\text { materials } \\
\text { Sign up for individual interviews }\end{array}$ \\
\hline $\begin{array}{l}\text { Provide feedback } \\
\text { Updates to Handbook }\end{array}$ & $\begin{array}{l}\text { Spring } \\
\text { Prepare for next round of goal setting and study }\end{array}$ \\
\hline
\end{tabular}


During the culmination sessions, the group will reflect on guiding questions. Teachers will be active participants in developing meaningful questions for use in the culminating event. The following questions are examples of the types of questions that may be used:

- Describe what you did in your attempt to grow in your areas of focus.

- How did this compare with former evaluation experiences?

- What are your results?

- What support did you receive from others that you found helpful?

- What obstacles did you encounter?

- How has your work influenced others?

- Is there a benefit to this process?

- How did your work benefit students?

- Would you do this process again?

- What suggestions can you make to improve the handbook or process?

- Did the network of teachers in the group help build lateral capacity?

- How has your teaching changed during this time?

To sustain democracy, students must emerge from our schools with a high level of literacy. Apple and Beane (1995) called for educators to engage at deep levels. They also expected educators to live their values, trust each other, be responsible for their learning, work with other organizations, and commit to the good of all. By empowering teachers, I believe we can realize democratic schooling - even a classy education for all students (Meier, 2001). To me, classy education assures that all students have literacy and numeracy, and all aspects of that education are engaging, meaningful, and transformative. I believe, as did Freire (1998a), that, "Whoever teaches learns in the act of teaching, and whoever learns teaches in the act of learning” (p. 31). I also ascribe to the view of school held by Freire and others that children are not empty vessels to be filled, but wonderful individuals who need the skills to be able to explore their world. I hope this process will hold meaning, lessen isolation, improve school, help teachers improve their own teaching, and build capacity for shared learning in the school. 


\section{GLOSSARY OF TERMS}

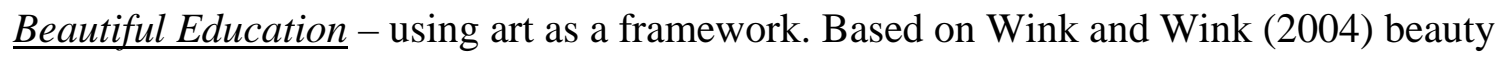
is compelling, elicits positive feelings and is consummate in its application in the classroom.

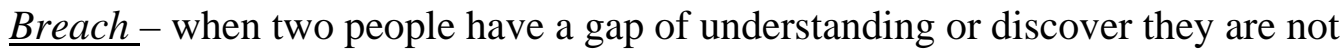
connecting, a breach develops. Awareness of this gap can lead to both people learning to bridge the gap, thereby connecting more effectively with each other.

Clinical Supervision and Evaluation - Emerging from the seminal work of Robert Goldhammer in the late 1960’s and Morris Cogan in the early 1970’s, clinical supervision is the most prevalent model of teacher evaluation. This approach includes goal setting, a pre-observation conference, in-class observations, and a post-observation conference. Contract Teacher - After working successfully for three years, the district designates a teacher as a contract teacher. Contract teachers can set one, two or three-year goals. Cycle of Continuous Improvement - based on work of Deming in which a person or group defines current reality, sets goals, plans, acts, then reviews reflects or evaluates and engages in change again - an iterative process. The spiral is used rather than the circle, because a learner can reflect back and look ahead on the spiral while working to improve. Democratic Education - calls for literacy as a moral imperative to future democracy. Makes space in the classroom for disparate views of all.

Dialogue - sharing ideas in a way that is not power over, but listening with the other person or people. Dialogue members strive to listen to understand the other person's position, not to impose their ideas on the other; can help all gain new insights. Formative Evaluation - captures continuous growth in teacher practice over time. 
$\underline{\text { Goals }}$ - are completed by contract teachers at the beginning of a new evaluation cycle.

Goals can be attainable in one, two or three year increments. Goal setting outlines an area of improvement set by each teacher. Goals are also set at the department, school, district and state levels, and are generally part of the School Improvement Plan (SIP).

Hermeneutics - the ongoing task of understanding the significance of lived experience, or the belief that meaning is based on interpretations of events of data. This knowledge is influenced by prior knowledge and presuppositions.

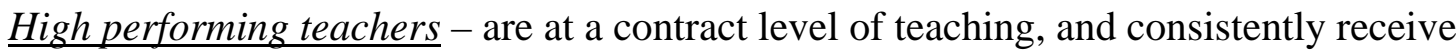
positive evaluative reports. They often take leadership roles within the school or district and participate in one or more school-wide improvement efforts. These teachers wish to re-examine and improve their own teaching. High performing teachers in this study will commit to the time required to journal, meet in a learning group and complete at least two study options.

Iceberg Model- based on Freud's initial work that there are conscious and subconscious ways of making observations. Ten percent of an iceberg is easily visible, with $90 \%$ below the water. Similarly, $10 \%$ of what we know when we interact with others is visible; $90 \%$ is not. Our actions are informed at all levels, including: structures, beliefs, and behaviors. Love in Education - It is impossible to teach without the courage to love (Freire, 1998). Love is predicated on high standards, rigorous demands and respect for students, their identities and their families (Nieto, 1999). Love connects us at deep levels (hooks, 2000). Mind's-Eye Model - from Wink and Wink (2004), a view that a person's experiences and identities inform all decisions they make interacting with those around them. 
$\underline{\text { Praxis }}$ - critical educator's practice of reflecting and questioning all decisions to determine if they help lead toward a democratic education for all students.

Problem Based Learning (PBL) - addresses a real problem and tool in education, and often helps practitioners offer improvements to aspects of practice.

Professional Learning Communities - groups of teachers who collaborate as a professional community to improve practices toward individual and shared goals based on work by Dufour and Eaker (1998) and Blankstein (2004).

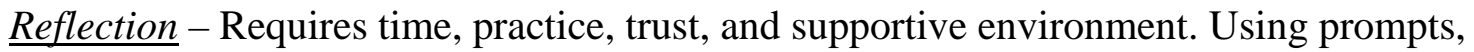
process or questions about instruction can lead to deeper reflection.

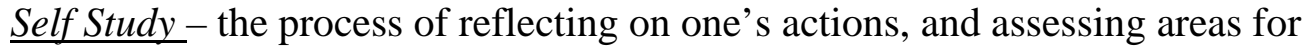
improvement or change. This is an iterative process.

Teacher-Leader - Teacher who is beyond probation, novice, or intermediate levels of performance. Refines practice. Serves on school improvement teams and may represent their curricular area at decision-making building or district level.

Teaching-learning - based on the work of Paulo Freire (1998a), who believes that teaching and learning cannot be separated (p. 29).

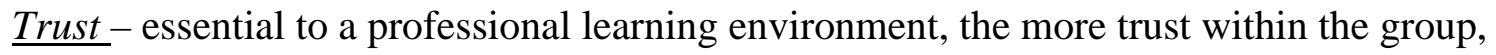
the greater the results they can achieve. Trust is an aspect of love. Trust is increased by honesty, integrity, reliability and dependability. High trust environments have a low rate of crises, and are focused on outcomes (Stillwell, 2003).

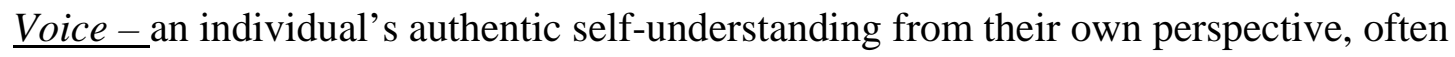
empowered and given credence by others in a dialogic environment. 


\title{
GROUP NORMS
}

\author{
Assume Good Intent
}

Come to this work fully engaged

Presume and extend welcome to all

Listen to understand the meaning of others

Embrace differences

Focus on what is possible for our students and ourselves

Learn from difficult feelings

Celebrate learning and accomplishment

Preserve deep confidentiality
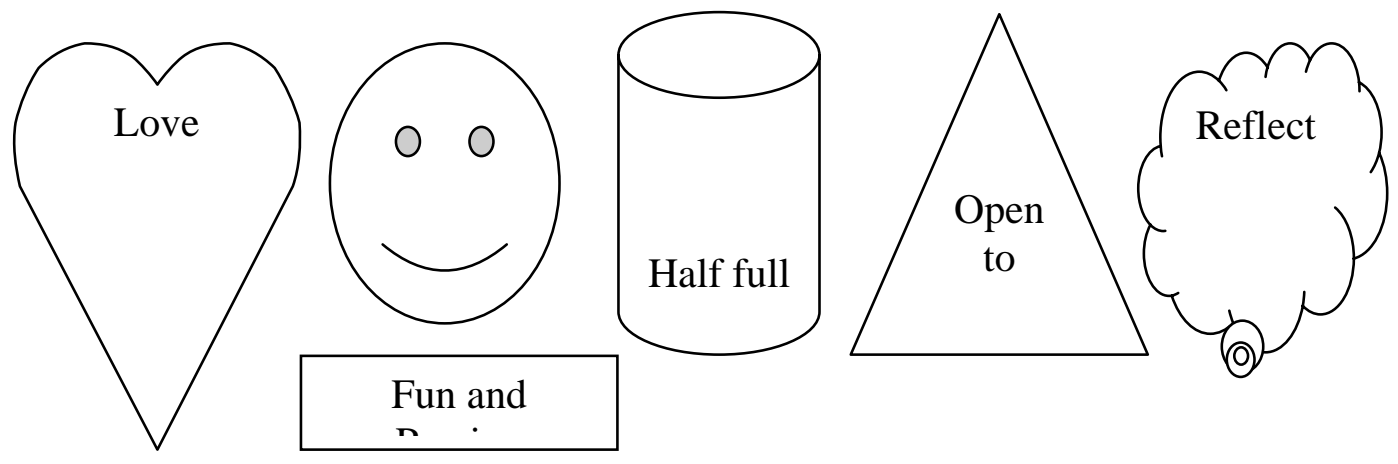


\section{TIMELINE}

The group will work from this example timeline.

\begin{tabular}{|c|c|}
\hline Assigned Topic and Reflection Questions & Purpose of Learning \\
\hline September & $\begin{array}{l}\text { Meet as a group } \\
\text { Conduct a self assessment } \\
\text { Set initial goals } \\
\text { Receive all materials } \\
\text { Select two options for self reflection } \\
\end{array}$ \\
\hline $\begin{array}{l}\text { October } \\
\text { Read Educational Leadership April } 2008 \\
\text { Poverty and Learning; and MLive.com } \\
\text { Kuskegon Chronicle “A third of public } \\
\text { school students live in poverty” } \\
\text { Question: How do we include all students? }\end{array}$ & $\begin{array}{l}\text { How do we make space in the classroom for } \\
\text { culturally responsive teaching so that students } \\
\text { feel included in their learning? The group will } \\
\text { explore suggested strategies and share strategies } \\
\text { that work in their classrooms. }\end{array}$ \\
\hline $\begin{array}{l}\text { November } \\
\text { Watch excerpts from Freedom Writers. } \\
\text { Question: How do your students’ realities } \\
\text { have space in your classroom? }\end{array}$ & $\begin{array}{l}\text { What do teacher and students do in the film? } \\
\text { Share out strategies used in classrooms or new } \\
\text { ones we can try. }\end{array}$ \\
\hline $\begin{array}{l}\text { December } \\
\text { View an interview with one student or } \\
\text { family. Use the Mind's Eye or Cultural } \\
\text { Iceberg to reflect on their perspective. } \\
\text { Question: How do your cultural values } \\
\text { compare and contrast with the values of } \\
\text { your students? Interviewees to explore this } \\
\text { question with us. }\end{array}$ & $\begin{array}{l}\text { Teachers will complete "T" chart to compare } \\
\text { and contrast their values and those they believe } \\
\text { their students hold. Teachers will be encouraged } \\
\text { to explore ways to learn more from their } \\
\text { students about the student reality in school and } \\
\text { in the community. }\end{array}$ \\
\hline $\begin{array}{l}\text { January } \\
\text { Read White Privilege P. McIntosh } \\
\text { Take Ruby Payne surveys of survival in } \\
\text { Poverty, Middle Class, and Upper Class. } \\
\text { Question: } \\
\text { What are the hidden rules of your classroom } \\
\text { and how do you teach them to your } \\
\text { students? }\end{array}$ & $\begin{array}{l}\text { Share reactions to White privilege, How can we } \\
\text { teach hidden rules in our middle class reality at } \\
\text { school to help students who do not have that } \\
\text { reality? }\end{array}$ \\
\hline $\begin{array}{l}\text { February } \\
\text { Participates in Culmination Session. }\end{array}$ & $\begin{array}{l}\text { Presentations and sharing products/experiences } \\
\text { Individual interviews of some teachers }\end{array}$ \\
\hline $\begin{array}{l}2^{\text {nd }} \text { session in February } \\
\text { Culmination presentations } \\
\text { Exit Survey } \\
\text { Goal setting }\end{array}$ & $\begin{array}{l}\text { Submit materials and goal setting forms for next } \\
\text { study and review processes }\end{array}$ \\
\hline
\end{tabular}




\section{INITIAL SELF-SURVEY}

In your self-reflection journal, please answer the following questions:

1. How do you feel about teacher evaluation? Do you find it meaningful? What do you expect from teacher evaluation?

2. What benefits do you expect from participating in this process?

3. How long have you taught in public school? At this school?

4. Please describe your age, gender, or other identity.

5. Describe recent professional development you found meaningful.

6. How would you like to develop as a teacher? Are you willing to make your classroom accessible to others?

7. How do you and your students analyze and improve learning tasks?

8. How do your cultural values compare and contrast with student values?

9. How can you optimize learning for each student?

10. What are your classroom's rules? How do students know them?

11. How do you create enthusiasm in your classroom and in the building? What can you commit to lead? How do you stimulate and spark others?

12. What are your passions and hobbies? How do you feel when you engage in them? How can personal passions come into your teaching?

13. Have you experienced exclusion such as racism or ablism? Have your students? 


\section{SELF STUDY JOURNAL}

Each teacher will maintain a reflective educational journal to reflect on his or her experiences. Writing in the self-study journal helps teachers thoughtfully and regularly reflect on their professional experiences and instructional practice to improve student learning. It forms a record of responses to professional reading or training, observations, feelings and insights about educational practices. When shared with a colleague, journals can start meaningful discussions about teaching and learning.

Some examples of events you can record are:

- $\quad$ Successes or challenges with lessons, units, programs or activities

- Interactions with parents or parent conferences

- Professional development sessions

- Ideas from books or articles

- Interactions with other teachers, students, specialists or administrators

- Student outcomes as evidenced by testing or other measures

- Students individual, small group or whole class experiences

- Insights or questions 


\section{SELF STUDY OPTIONS}

One effective school improvement strategy is to make classroom walls more permeable. To increase collegial connections, at least two teachers must select each option for that option to be used. Additionally, since one goal is to improve student outcomes, each teacher or teacher team will determine what impact their participation in a study option has on students in the classroom.

\section{Transformative Options: (Choose two)}

1. The Iceberg Model. This model provides a structure to reflect on any area of teaching and learning; the goal is to reflect below the surface.

2. The Mind's Eye Model. This model helps teachers reflect on their own beliefs, then learn about student beliefs to better understand both perspectives. The goal is to learn about disconnections or assumptions between the teacher and the student so that they can build closer connections in the classroom.

3. Democratic School Attributes in Your Teaching. This set of questions leads to conditions in the classroom in support of deep inclusive democracy. These questions could guide all the teacher's work in the classroom.

4. Spiral Model of Continuous Improvement. This schema helps a teacher select a practice, try it, reflect on the experience and outcomes, and then plan again. If selecting this model, the teacher will use the model to characterize one or more aspects of his or her teaching during the self-evaluation process. 
5. Student Surveys. Questionnaires or surveys are often used in university settings to gain feedback from students about their experiences in class. The purpose of this survey is to make sure students understand classroom processes and to gather their perceptions. Teachers can use student feedback to improve class. A parent survey is included for teacher consideration.

6. Community and Home Visits. Teachers will accompany others to conduct home visits. Teachers can then reflect about the interactions in the home and how they can apply this knowledge to connect more effectively with students.

7. Use the Structured Instruction Observation Protocol (SIOP) as a framework for evaluating your teaching. SIOP is a best practice for teaching English as a Second Language, but may prove effective for children of poverty.

8. Educational History. Create your own educational history. Ask one or more students to create their educational histories, then, compare and contrast. You may also compare educational histories with colleagues. 


\section{OPTION 1: THE ICEBERG MODEL}

The Iceberg Model helps examine what happens below the surface. An actual iceberg is located of $90 \%$ below the surface. Only $10 \%$ is readily visible. In most teacher evaluation cycles, the administrator comes in to view the classroom several times; there is a post conference and a final write up. Without additional reflection with the teacher, the evaluator can view only what is readily seen. In fact, the visits capture a tiny fraction of the teacher's experience in the classroom. Therefore, it is highly unlikely that this kind of process can capture the complexities of teaching and learning.

You are uniquely situated as a teacher with students to reflect below the surface. You know your students and their interactions with you better than any outside observer. To use this model, you will assess one aspect of your teaching using one blank iceberg. Then, you can reflect on the same aspect of your teaching each month, perhaps setting a goal to see change in one area or at a particular level of interaction with students. At the close of the project, you will present the completed iceberg, and journal about your learning in the process. 


\section{ICEBERG MODEL OF TEACHER EVALUATION REFLECTION}

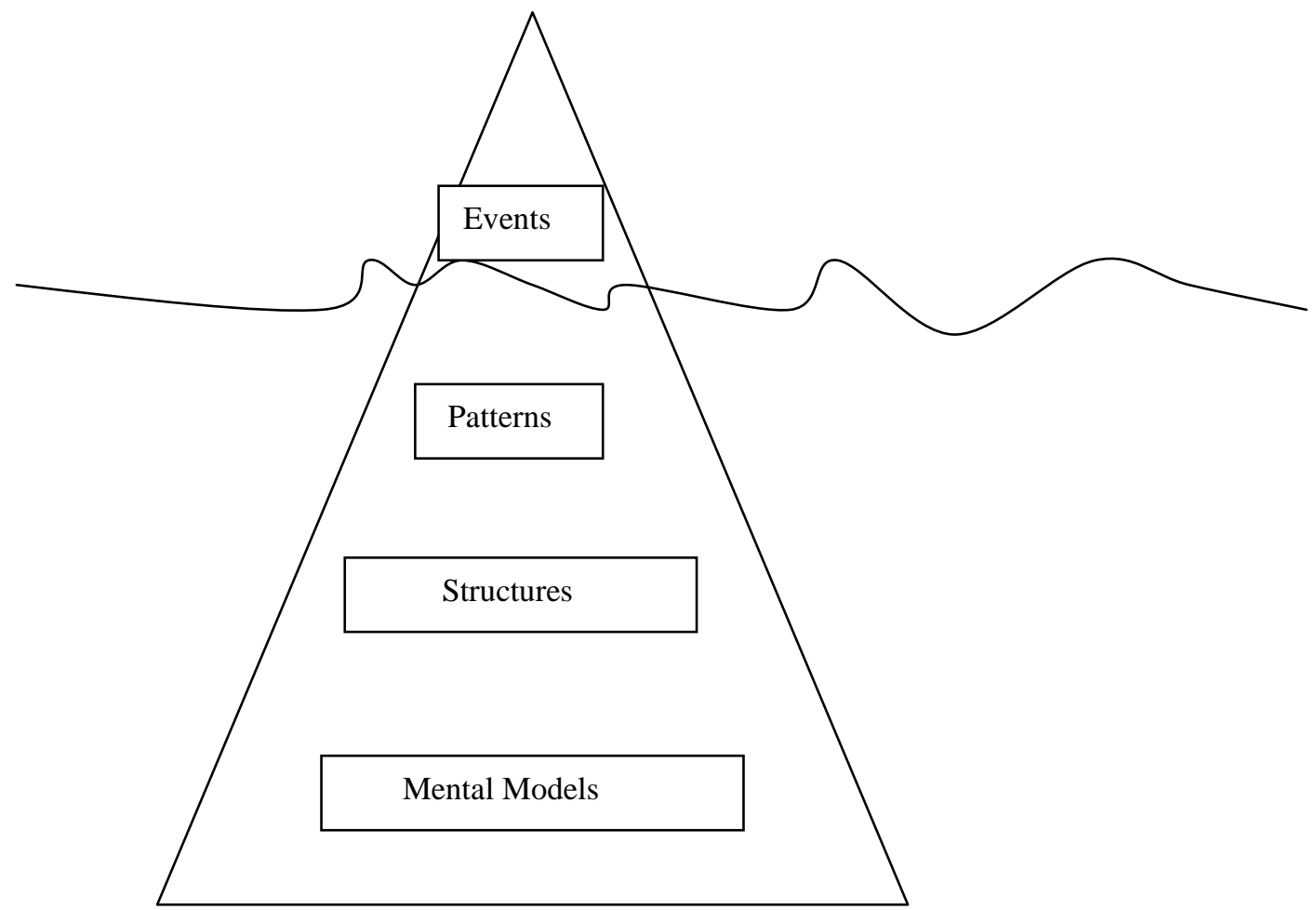

Events are observable and account for a small part of how we make decisions in any situation. Teacher evaluation observations only capture obvious information or activities. What was seen or heard? Knowledge is made up of concrete facts.

Patterns are events that repeat in similar ways, trends. We can chart behaviors over time to observe patterns. Examples in education are: behavior plans, tardy trends, or student tracking charts. These are measurable and reportable. Another example is a pattern of trustworthy behavior. What events predict what outcomes? How do we want the trend to change? Facts follow patterns and are organized by predictions observed in the past.

Structures are ways that we predict behavior. School examples are: the Master Schedule, hiring practices, leadership, evaluation, bell schedules, and rules. Structures predict what will or most likely will happen. What structure do we use in school - middle class expectations? What are the hidden rules of school? What interconnections produced the structure? What structures guide student realities? How can we optimize each student's learning? Is my classroom practice helping students to be their best?

Mental models are belief systems. Examples are love, humanism, cultural values, attitudes, ethnocentrism, history, trust, bias, moral purpose, consistency, commitment, openness to change, adherence to tradition, and integrity. One belief is that school improvement is continual, complex, and dynamic. What changes in mental models would produce improved patterns, trends, and events? Consider another perspective. What inferences do we make based on our mental models? What are strengths and weaknesses of different views? Learning happens from making abstractions, or understanding reality in a different way.

To work more effectively with others, we must look below the surface! 
The following is an example of how you could use the Iceberg Model to reflect on your own teaching with your students.

$\underline{\text { Steps for using the Iceberg as a model for Reflection }}$

Adapted from Bogdan and Biklen (2003)

Step 1: $\quad$ Pick a focus problem

Examples could be: a troubled relationship with a student or group of students, a particular habit of yours you want to change, or a specific style you want to nurture.

Step 2: $\quad$ Keep detailed notes on the issue, recording observations and dialogue whenever possible. Enter them on the Iceberg Model to determine the depth of the interactions. Record what the student does and says to you and others. Write down when you exhibit the behavior you want to change or nurture and with whom. What are students’ reactions? Do any students reinforce positive behavior? Do they react negatively?

Step 3: Look through your data for any patterns that emerge. Ask questions about what stands out. Find areas of disconnect with students. Do you discover behaviors that work? How would you characterize the atmosphere in your classroom?

Step 4: $\quad$ Use data to guide your continued teaching practice. Sometimes, recording vents can improve teacher practice. You may use knowledge in a new way to improve your teaching. You may share what you discover with students or other teachers. Decision-making is specific to your individual situation. 
You can use this in-depth description of the levels of inquiry to guide your reflection. Reflection happens at each level of inquiry.

\section{LEVELS OF INQUIRY}

Professional inquiry about your own practice can happen at different levels. These levels are similar to the visual representation of surface and deep learning offered by the Iceberg Model. My hope is that teachers will delve deep, at the mental model level or the critical level. Each teacher will determine the level of his or her own reflection. The levels offered by Holland et al, are:

Empirical Perspective - a study of observable and measurable events. Can be detailed and descriptive of the environment. This is the surface level with some implications for below the surface reflection using the Iceberg Model.

Hermeneutic Perspective - a study based on interpretations of events of data. This knowledge is influenced by prior knowledge and presuppositions. This equates to a just-below-the-surface level in the Iceberg Model or slightly below that.

Critical Perspective - a study to expose power relationships and mental models or deeply held beliefs. The concern is how teachers and students can be empowered as active participants in a democratic creation and use of knowledge. Freire (1998a) contends that teaching and learning cannot be separated and are political. This level places teaching and learning in a socio-economic context. This aligns to the Mental Model level. 


\section{ICEBERG MODEL FOR TEACHER REFLECTION}

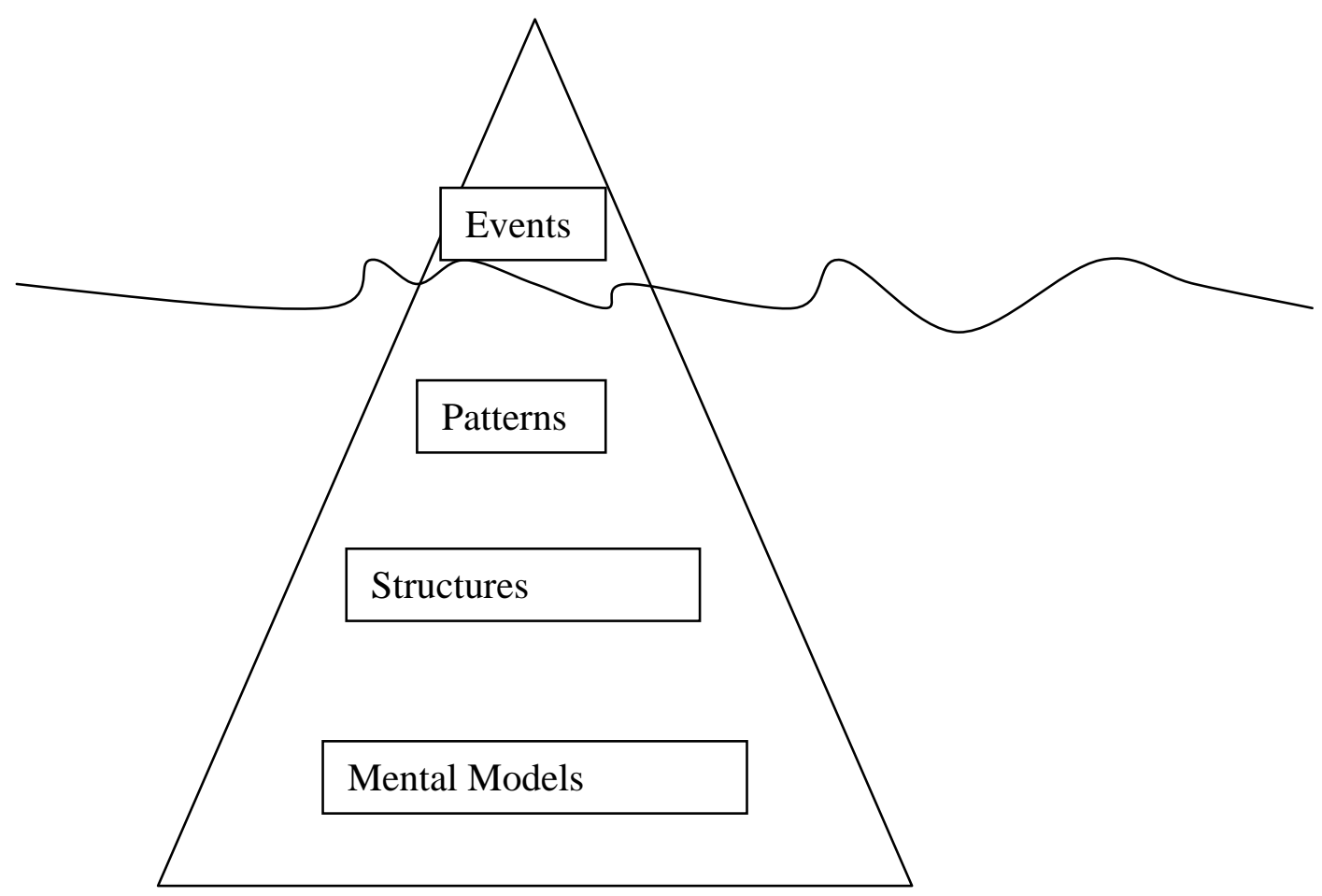

What event happened?

What patterns do you want to improve or change in your classroom?

What structures predicted events and patterns in your classroom? What do you want to keep or change?

What mental models do you and your students hold? Where are the connections or disconnections? 


\section{OPTION 2: MIND’S EYE MODEL}

We all come to this work with our personal experiences, cultural realities, religious beliefs, and socioeconomic class. In our talking and actions, Wink and Wink (2004) remind us that our human experience determines the lenses we use:

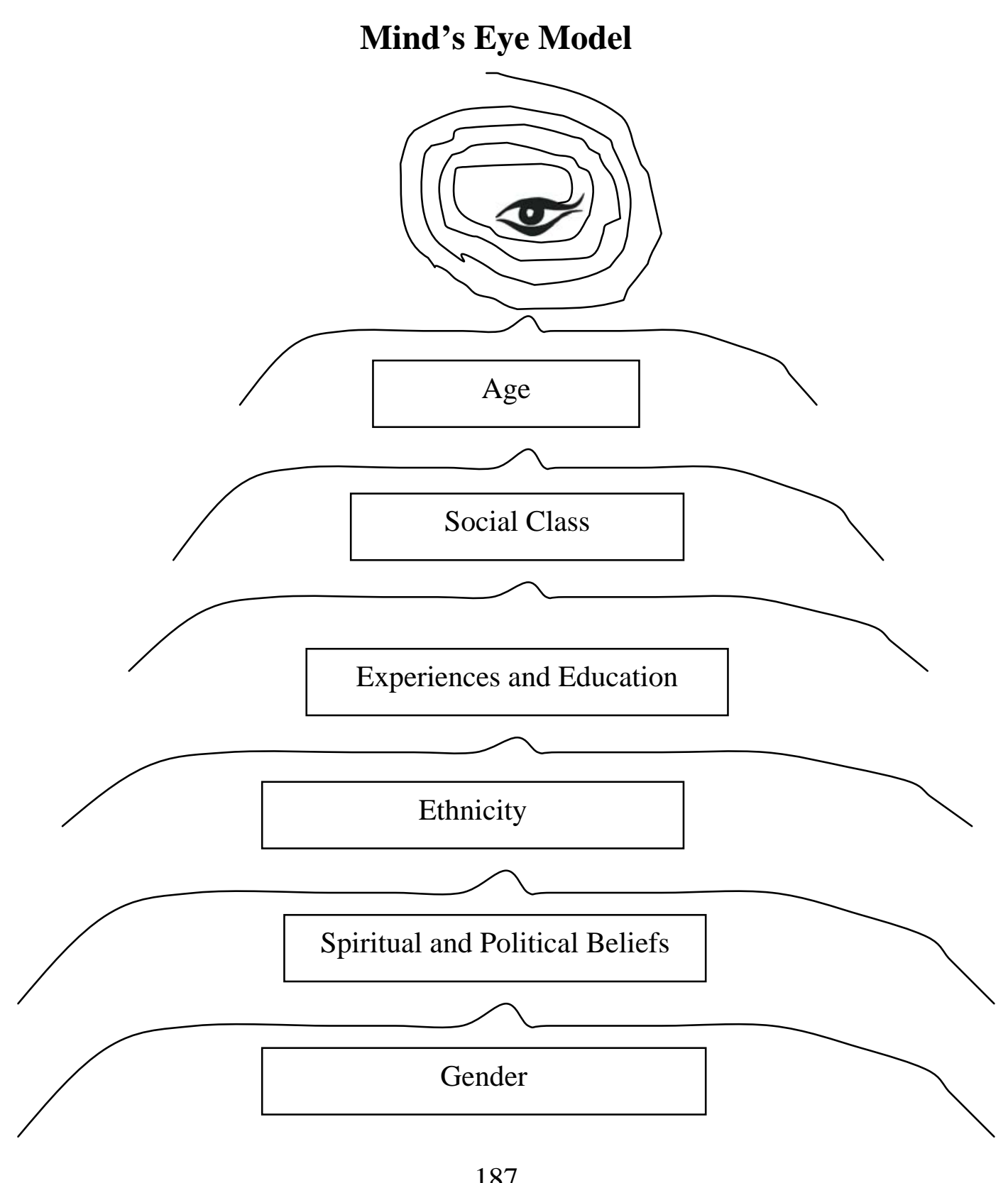


From our earliest existence, life happens within a cultural, spiritual, political, economic context. Shared beliefs determine how age, gender, education, and ethnicity influence group members. Many students have experiences other than our own. Explicitly knowing our own and our students' beliefs can help us connect with each other at deeper levels. To treat our students as they would wish to be treated (sometimes the same and sometimes different from how we wish to be treated) is an act of love and empathy. We think for a purpose, within a point of view, use our assumptions and experiences, make inferences, and come to judgments. When we know our values, love others, and view difference as strength that beautiful education become possible.

Complete a blank Mind’s Eye to represent your own experiences. Reflect on what you bring to the classroom from your own identity. During this study, consider one student or group of students in your class who you would like to better understand. Complete a Mind's Eye model of the student's reality as you know it or think about it. Then, conduct a family conference and let the family know you really want to understand their experiences. Complete one Mind’s Eye a month, or construct a comparative table. Each month, complete the following reflective questions in your journal:

o What strikes me about my own Mind's Eye?

o What strikes me about the student's Mind's Eyes?

o What steps can I take to learn more about my students' realities?

o How can I close the gap between their reality and my reality? 


\section{OPTION 3: DEMOCRATIC SCHOOL ATTRIBUTES}

Apple and Beane (1995) identified the essential attributes necessary for democratic school:

- The open flow of ideas, regardless of their popularity, that enables people to be as fully informed as possible.

- Faith in the individual and collective capacity of people to create possibilities for resolving problems.

- The use of critical reflection and analysis to evaluate ideas, problems and policies.

- Concern for the welfare of others and "the common good."

- Concern for the dignity and rights of individuals and minorities.

- An understanding that democracy is an "ideal" to be pursued as an "idealized" set of values that we must live and that must guide our lives.

- Social institutions organized to promote and extend the democratic way of life.

Reflect on your classroom. Which aspects can you focus on within your teaching? Chose one or more aspects and begin measuring the presence, absence or challenge to make these aspects realities in your classroom. Do students gain experiences that prepare them to live in a democratic society within your classroom? Are the rights and dignity of all safeguarded? 


\section{OPTION 4: SPIRAL MODEL OF CONTINUOUS IMPROVEMENT}

The Spiral Model of Continuous Improvement is a schema that represents a commitment to continuous improvement. This approach has been central to the work of Costa and Kallick, Chenoweth and Everhart, and Deming. This spiral schema helps guide a self-study cycle. This is a process that schools use to reflect on their mission and goals, practices and results, and general operation through collection, creation and review of documents and other information. The spiral as a representation suggests that there is no beginning and ending point, but that improvement is continuous. It allows for implementation dips or for progress that is not always linear.

Essential questions suited to the Spiral Model of Continuous Improvement are: Why is performance as it is?

What is the whole picture?

What is the school doing to enable all students to make progress?

What is the teacher doing to make sure all students are making progress? 


\section{SPIRAL MODEL OF CONTINUOUS IMPROVEMENT}

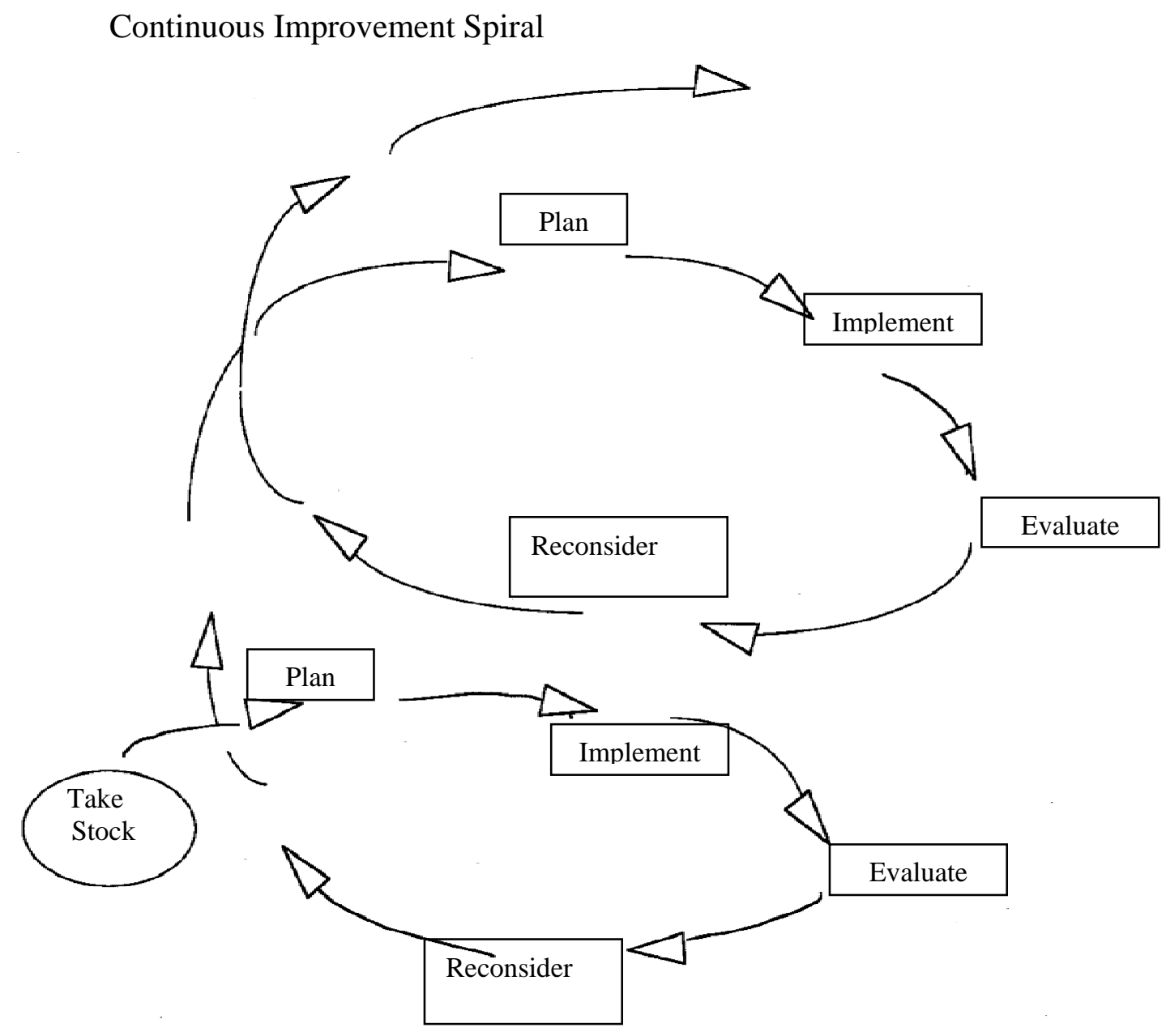

Select an aspect of your teaching such as a lesson. How did the students learn from a lesson or a structure in your classroom? Complete one spiral a month depicting your own classroom experience. Reflect in your journal about your experience with this tool. 


\section{OPTION 5: STUDENT QUESTIONNAIRES}

Surveys are used to gather views about school from perspectives other than our own. Parent and student surveys have been used to provide feedback for school improvement. At many universities, students regularly complete surveys at the end of a course. Information is gathered anonymously and then shared with the professor.

Students experience teaching and learning in the classroom with the teacher every day. Surveys help students share their perspectives with their teachers. Teachers can compare student responses and observations with the intended lesson or practice. The Middle School and High School Survey Form used in this study was developed by Peterson and Peterson (2006). They suggest teachers use this survey form as a source of data to use to reflect and recalibrate instruction.

Another option used by many school districts is a parent survey. A sample parent survey is included in this pilot handbook for your consideration. It is similar to the student survey, and could be helpful to gather parent perspectives.

You can use this questionnaire at the beginning of this study and regularly thereafter. You may add a question as you use the survey. What trends or changes emerge? You may develop your own questions. If these questionnaires were used within a grade level team, how could our teaching improve? Do we believe what our students tell us? 


\section{$\underline{\text { Middle School and High School Student Survey Form }}$}

\begin{tabular}{|c|c|c|c|c|c|}
\hline \multirow[b]{2}{*}{ I know what I am supposed to do in class } & \multirow{2}{*}{$\begin{array}{l}\text { Agree } \\
5\end{array}$} & \multicolumn{2}{|c|}{ Not Sure } & \multicolumn{2}{|c|}{ Disagree } \\
\hline & & 4 & 3 & 2 & 1 \\
\hline Teacher shows us how to do new things & 5 & 4 & 3 & 2 & 1 \\
\hline There is enough time to finish class work & 5 & 4 & 3 & 2 & 1 \\
\hline This class is not too noisy or rowdy for learning & 5 & 4 & 3 & 2 & 1 \\
\hline I like to come to this class & 5 & 4 & 3 & 2 & 1 \\
\hline I learn new things I can tell you about & 5 & 4 & 3 & 2 & 1 \\
\hline I know how well I'm doing in this class & 5 & 4 & 3 & 2 & 1 \\
\hline This is a good teacher & 5 & 4 & 3 & 2 & 1 \\
\hline We have enough materials and supplies to learn & 5 & 4 & 3 & 2 & 1 \\
\hline \multicolumn{6}{|l|}{ At the end of class, I understand the assignment } \\
\hline well enough to finish it & 5 & 4 & 3 & 2 & 1 \\
\hline This teacher treats me fairly & 5 & 4 & 3 & 2 & 1 \\
\hline I know why we learn what we learn in this class & 5 & 4 & 3 & 2 & 1 \\
\hline This class is not too slow or fast to learn well & 5 & 4 & 3 & 2 & 1 \\
\hline The rules in class help us to learn & 5 & 4 & 3 & 2 & 1 \\
\hline
\end{tabular}

(From Peterson \& Peterson, 2006, p. 54) 


\section{Middle School and High School Parent Survey Form}

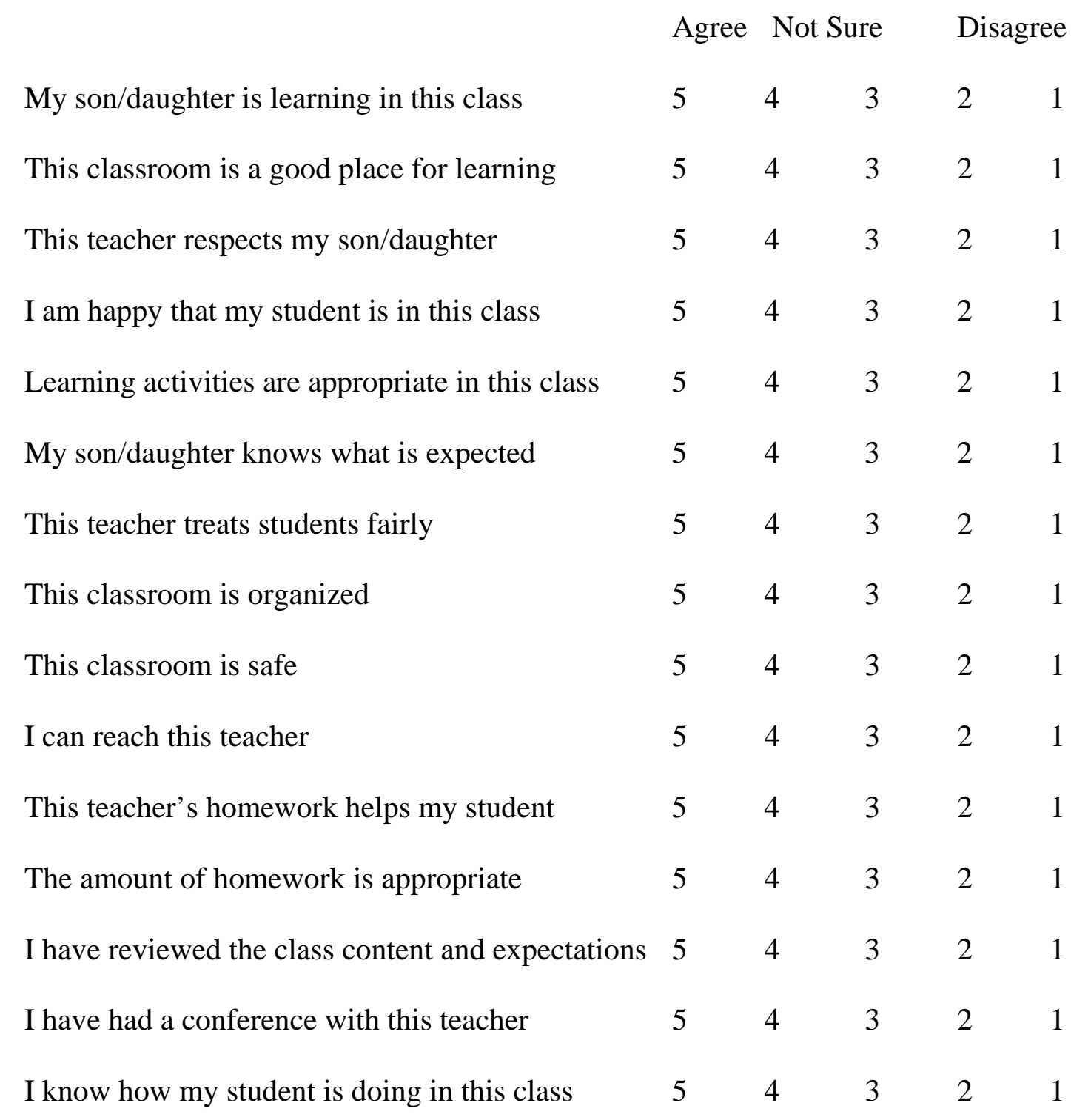




\section{OPTION 6: COMMUNITY AND HOME VISITS}

Student experiences in their community affect how they view the world. Although teachers care about their students, they are often unfamiliar with the community in which students live. This is particularly true if teachers live outside student community and commute to work. Humans naturally make assumptions about others to make sense of the world. We make these assumptions informed by our individual experiences. While the majority of our students experience poverty, teachers experience middle class. While our school is a minority-majority school, teachers are predominantly white. Additionally, when students and teachers return home, they generally stay within their own communities.

Teachers are curious about their students' lives outside school. This option gives teachers in pairs or in groups a chance to know their students' community. How do student realities outside of school inform our classrooms? How can we make space in our classrooms for students? How can the community support our work? If a breach of understanding occurs, teachers can bridge the gap, learn about students, and be more aware of themselves and steps they can take to connect with students. 


\section{Steps for Community and Home Visits}

Step 1: $\quad$ Drive our school attendance area. Compare and contrast wealth and poverty. What do you notice about where our students live? How does what you see compare with your home community?

Step 2: $\quad$ Visit our other two middle schools when they are in session. How does our school compare to the other schools. Develop a chart to compare the schools.

Step 3: $\quad$ Go on a home visit with a social worker or attendance counselor. What are your reflections?

Step 4: $\quad$ Ride along with our Student Resource Office.

Step 5: $\quad$ Visit a church service with a student and his or her family

You may develop another protocol for community visits. In any case, reflect in your journal about what you have learned. What else can you learn in our community about our students? 


\section{OPTION 7: SIOP LESSON PLANNIG}

Structured Instructional Observation Protocol (SIOP) is a best-practices approach to teaching English as a Second Language. All aspects of this lesson planning approach focus on increasing student academic language skills. SIOP lessons provide ample options for speaking, listening, reading, and writing. These are the elements of literacy. Although it was designed with English Language Learning (ELL) in mind, this approach may prove valuable, as it may be quite effective in helping children experiencing poverty or those experiencing challenges in literacy to improve.

Poverty research reports that children experiencing poverty often have fewer words in their vocabulary as compared to the vocabulary of middle or upper class children. Because SIOP pre teaches vocabulary and scaffolds learning for students, this model should be tried in general classroom settings.

This option gives you the SIOP lesson-planning framework. You can plan a lesson, reflect on the lesson's effectiveness, and use the model again. Explore this model as a potential way to improve instruction. Have FUN! 


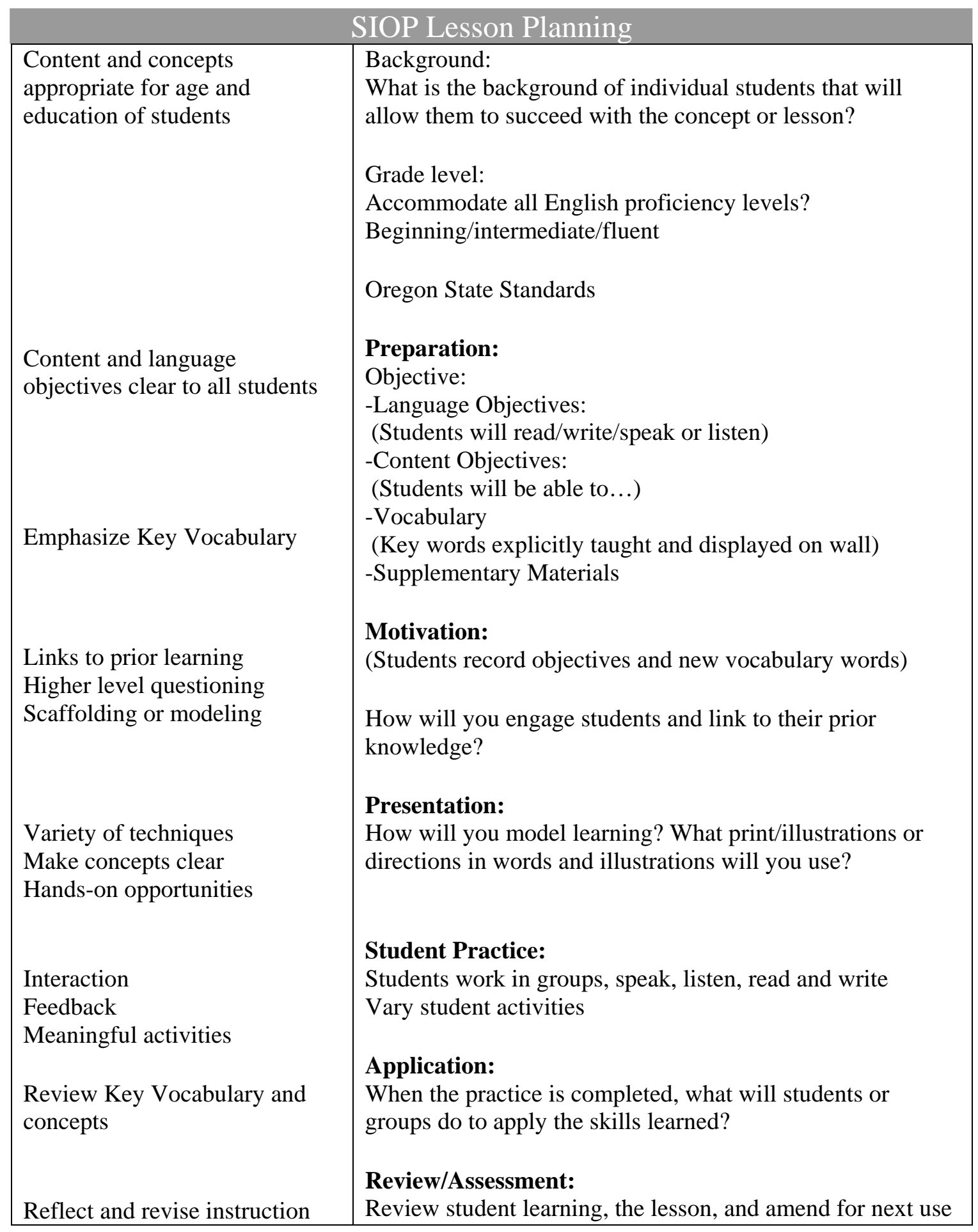




\section{OPTION 8: EDUCATIONAL HISTORY}

\section{Introduction}

This exercise gives you the opportunity to capture memorable events in your own educational experience. Once you complete your timeline and narrative, you can compare them with students or colleagues. Often, we teach by repeating practices we experienced in our childhood, or we make assumptions that others had similar experiences. By developing a keen understanding of similarities and differences, a breach can be evident. The steps we take to close the breach can help teachers and students or teachers and colleagues connect in more informed ways.

\section{Reflection Questions}

- Who is the first teacher you remember and why?

- Describe classroom settings you remember, negative, and positive.

- How did you feel emotionally and physically during these years?

- What do you remember about $\mathrm{K}$ to $2^{\text {nd }}$ grade? $3^{\text {rd }}$ to $5^{\text {th }}$ ? $6^{\text {th }}$ to $8^{\text {th }}$ ?

- How did a teacher do when a learning opportunity was difficult for you?

- Describe the teacher who influenced you most during this time.

- Describe attributes you show during teaching with your students.

- Develop a timeline and any highlights you recall from K through $8^{\text {th }}$ grade. 


\section{QUICK WRITE FOR SELF EVALUATION LEARNING SESSION}

Teacher Name

Date

What I learned during this session
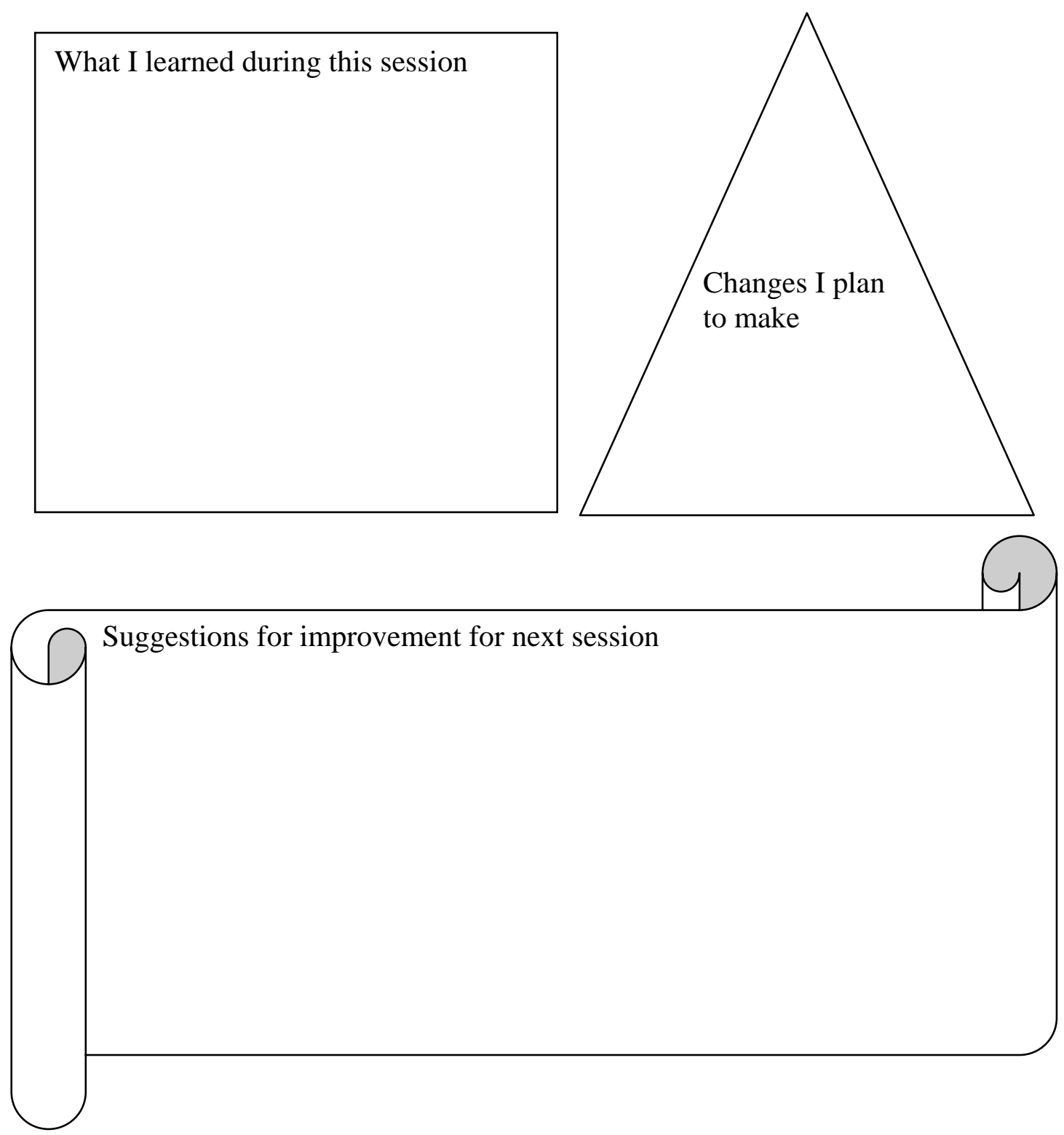


\section{EXIT SELF SURVEY}

Now that this study period is ending, how do you feel about this process? What have you learned? Please answer the following questions. What has changed?

1. How was your experience in self-study process compared to past experiences? How was it meaningful or different? Would you do this process again?

2. How would you like to develop as a teacher? Have your ideas changed?

3. Did you make your classroom accessible to others? What was this experience like?

4. How do you and your students analyze and improve learning tasks?

5. How do your cultural values compare and contrast with student values?

6. How can you optimize learning for each student?

7. What are your classroom's rules? How do students know them? Did you change them during this time? If so, how?

8. How do you create enthusiasm in your classroom and in the building? What can you commit to lead? How do you stimulate and spark others?

9. During this time, were you able to bring your personal passions into your teaching?

10. Have you experienced exclusion such as racism or ablism? Have your students? Did you learn about new experiences in this study?

11. At this time, what are your curiosities about your teaching? 


\section{GOAL SETTING PROCESS}

The following suggestions help guide teacher goal setting for the next professional development cycle. Goals align to the school improvement plan, performance standards, District values and District goals. Goals can be written in concert with another colleague or group of educators. Set one to two meaningful goals, and focus on your growth.

\section{Suggestions:}

$\checkmark$ Write a goal that enhances your strength in an area for which you excel.

$\checkmark$ Write a goal that requires you to work closely with at least one other colleague.

$\checkmark$ Write a goal that leads you to learn and implement new areas in your instruction.

$\checkmark$ Write a goal that creates chances for you to closely interact with a student or group of students with whom you want to be more effective.

$\checkmark$ Write a goal that leads you to use data in your teaching and planning.

$\checkmark$ Write a goal that builds on your use of technology.

$\checkmark$ Write a goal that helps you learn about a culture not familiar to you.

$\checkmark$ Write a goal to increase literacy in your instruction.

$\checkmark$ Write a goal to improve work sample quality that you elicit from your students.

$\checkmark$ Write a goal that leads you to share your ideas with others such as: presenting at a conference, publishing, competing with a group of students, or leading professional development sessions. 


\section{PROFESSIONAL GOAL SETTING AND ACTIVITY FORM}

EDUCATOR: Subject/Grade:

Date:

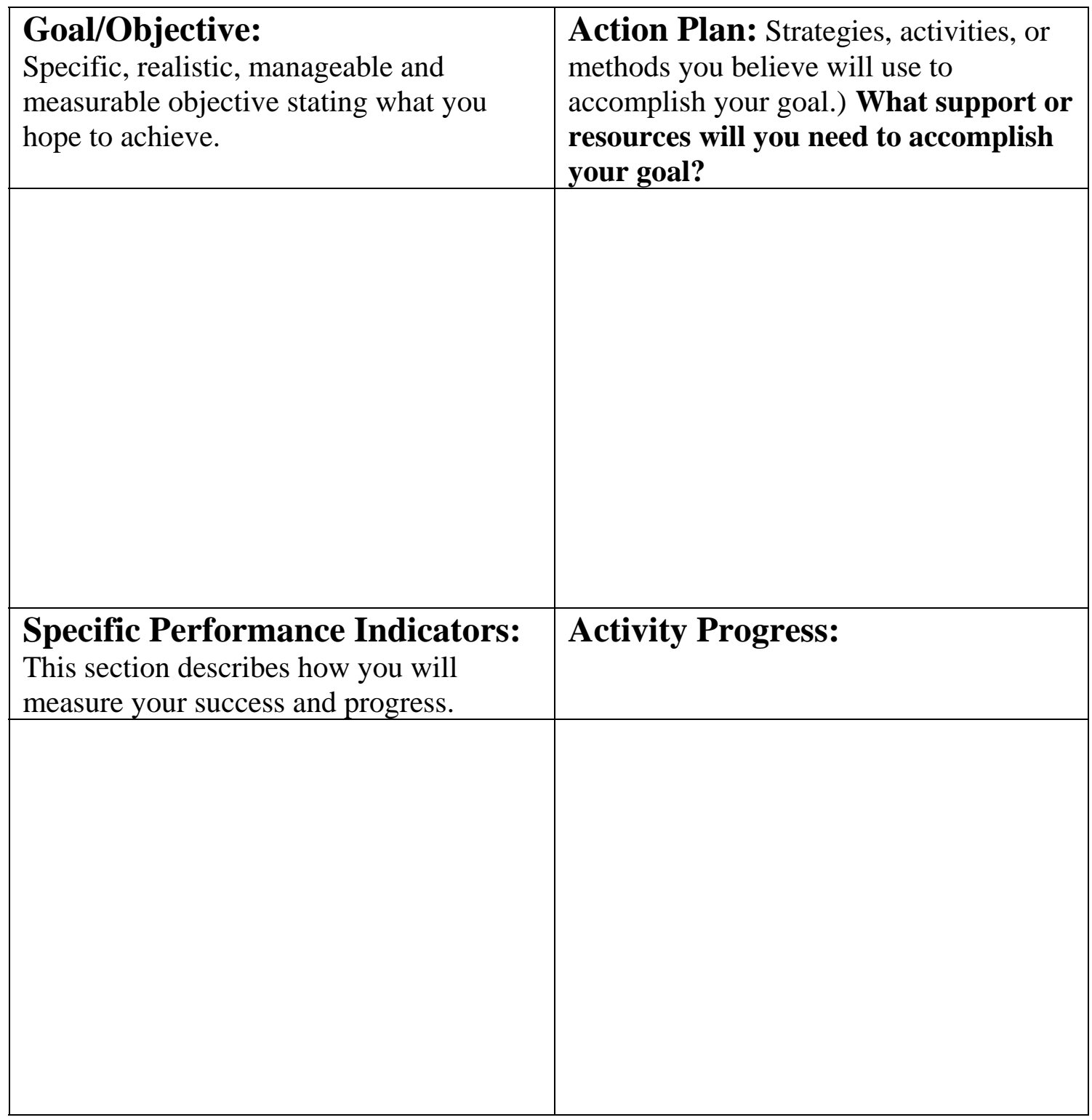




\section{EXIT INTERVIEW QUESTIONS}

- Describe what you did in your attempt to grow in your focus areas.

- How did this compare with former evaluation experiences?

- Provide a summary or other evidence of outcomes

- What support did you receive from others that you found helpful?

- What obstacles did you encounter?

- How has your work influenced others?

- Would you do this process again?

- What were the unanticipated benefits or pitfalls?

- Did teachers in the group help build lateral capacity?

- Has your teaching changed during this time?

- What suggestions can you make to improve the handbook or process?

To prepare for the culmination sharing activity, teachers will select a few of these questions or develop different questions; the group may revise these questions. 
APPENDIX B

TEACHER PRODUCTS 

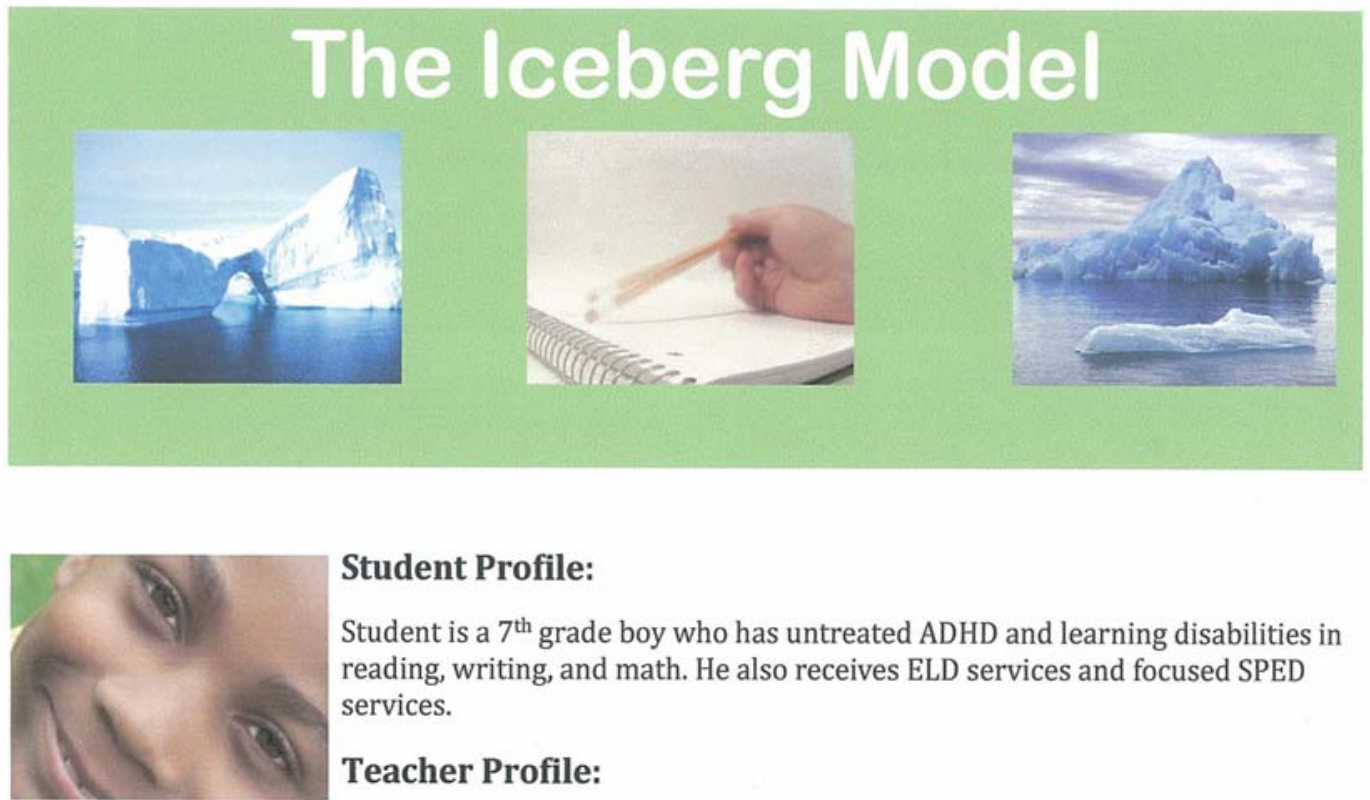

\section{Student Profile:}

Student is a $7^{\text {th }}$ grade boy who has untreated ADHD and learning disabilities in reading, writing, and math. He also receives ELD services and focused SPED services.

\section{Teacher Profile:}

Teacher \#1: $7^{\text {th }}$ grade SPED teacher. Case manages student and provides intervention by way of Tutorial 2 periods per day with student.

Teacher \#2: $7^{\text {th }}$ grade math teacher. Provides direct service to student in a supported class.

\section{Prior to Intervention}

\section{Events:}

Student Behavior: Impulsive shout-outs, constant talking, tapping of pencil/pen, interfering with other students learning. off-task even if quiet (drawing, etc.), consistent tardiness and unprepared, seemed to want to entertain class

Teacher Behavior (in response): taking away distracting materials, warnings, tracking behavior, lunch detentions, parent phone calls, seating chart, after-school detentions, removal from class, office referrals, referral to support services

\section{Patterns:}

Student involved in lesson, student on time and with materials, improve in-class instructional time, improve homework completion and class participation, to improve skill level, create an environment without interruptions so everyone can learn.

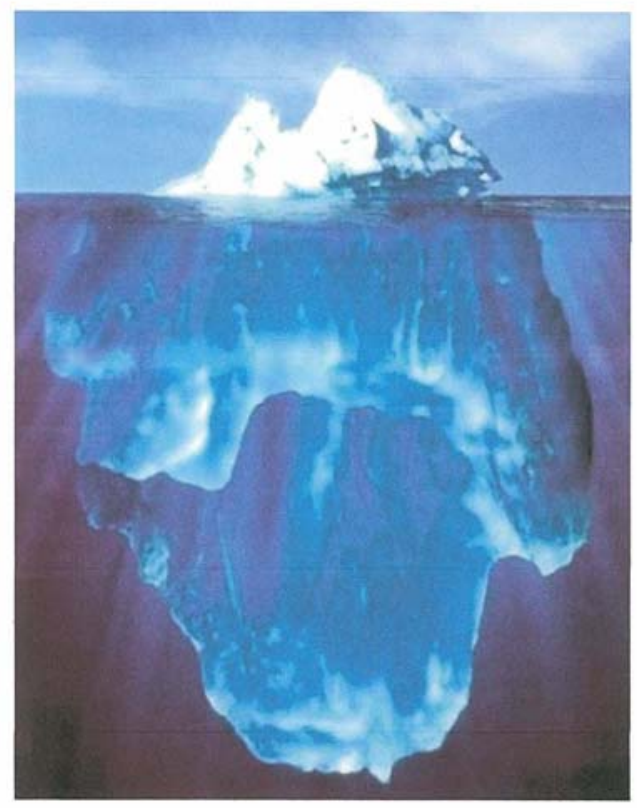




\section{Structures:}

Student's behavior when entering the classroom often indicates the type of behavior that will be displayed in the classroom. If student does not have work completed, will be off task and distract others. If student is around certain other students, the student feels the need to entertain them.

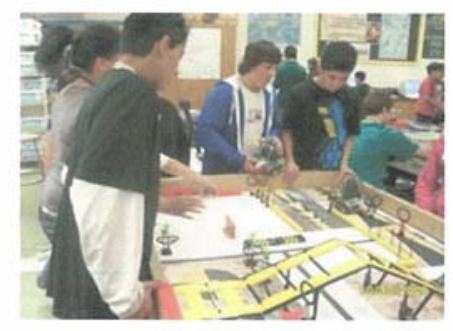

\section{Mental Models:}

Student Belief System: Negative image of self, both academically and physically. Comedy is a method to get social approval from peers, does not view self as a "student." Sees very limited hope for the future.

\section{Teacher Belief System: The} belief system was that the student had the ability to be successful regardless of the current behavior that was being shown. The belief system among the teachers was that a collaborative and consistent approach would increase student success.

\section{Intervention}

Student was given a referral to El Programma Hispano which gave information regarding students inability to stay after for detentions due to childcare responsibilities at home.

Student's schedule was changed to place him in two Tutorial classes to provide greater academic support and placed in a different math class to minimize contact with another student who was making academic improvement a challenge.

Student had behavior goals added to IEP during meeting with parents and a check-in/ check-out was added to daily routine.

Parents shared about ADHD diagnosis and the reason that it was untreated was due to lack of insurance or ability to access free healthcare in the community.

\section{After Intervention}

\section{Events:}

Student Behavior: On-time to class with supplies ( $80 \%$ of time), finds seat with minimal distraction to other students ( $85 \%$ of time), decreased shout outs, increased appropriate student behavior (raising hand, participating in lesson, listening to lesson), increased academic grade, increased homework completion

Teacher Behavior: Positive encouragement, rewards for on-task behavior, positive tracking, minimal detentions or referrals to office. 


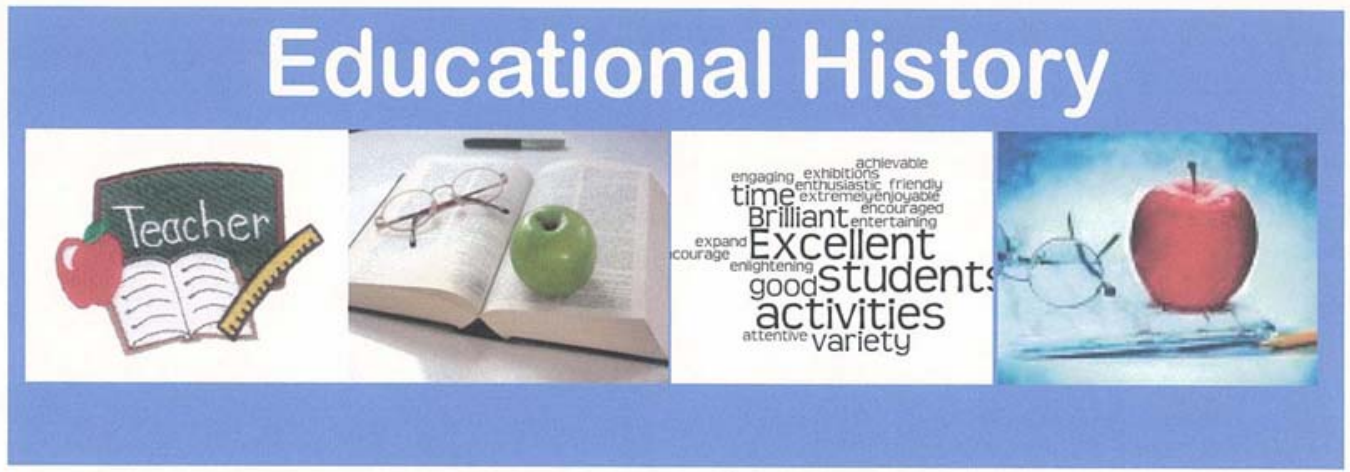

Our Educational History is a tapestry woven with the threads of our educational experiences. Each thread an experience that is forged from teachers, students, and others who we come in contact with. Each of these experiences help to determine what type of student we will be and ultimately, for those who choose the field of education, what type of teacher we will become.

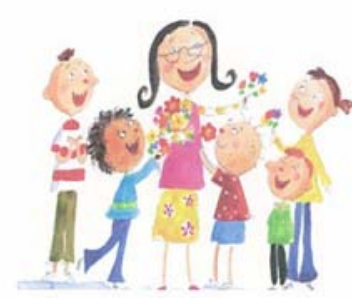

educational experiences. Writing these experiences down can illustrate patterns that have occurred over time. These patterns of success or failure have molded how we view ourselves as learner. Woven into this view is the impact of teachers and other adults who crossed our path.

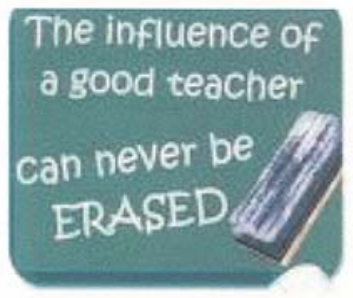

How does our educational history impact our desire to teach?

Our experiences as a student help form our beliefs about ourselves as learners and potential leaders. Although these experiences are powerful teachers, our actual teachers are often the ones who make the greatest impact on us. This impact often guides us to have the desire to mold and impact other young lives and become a teacher.

\section{How do our educational experiences make us better teachers?}

Each of us walk away from our educational experiences changed. We walk away with a firm grasp of who we see ourselves to be and our desire to be that same impact on our own students is strong. We take all of our experiences and use them to provide a framework for our students so they can achieve to their fullest. Providing academic opportunities based on the framework of our experiences is our ultimate goal. 
Adaptable

Impowered working Joget

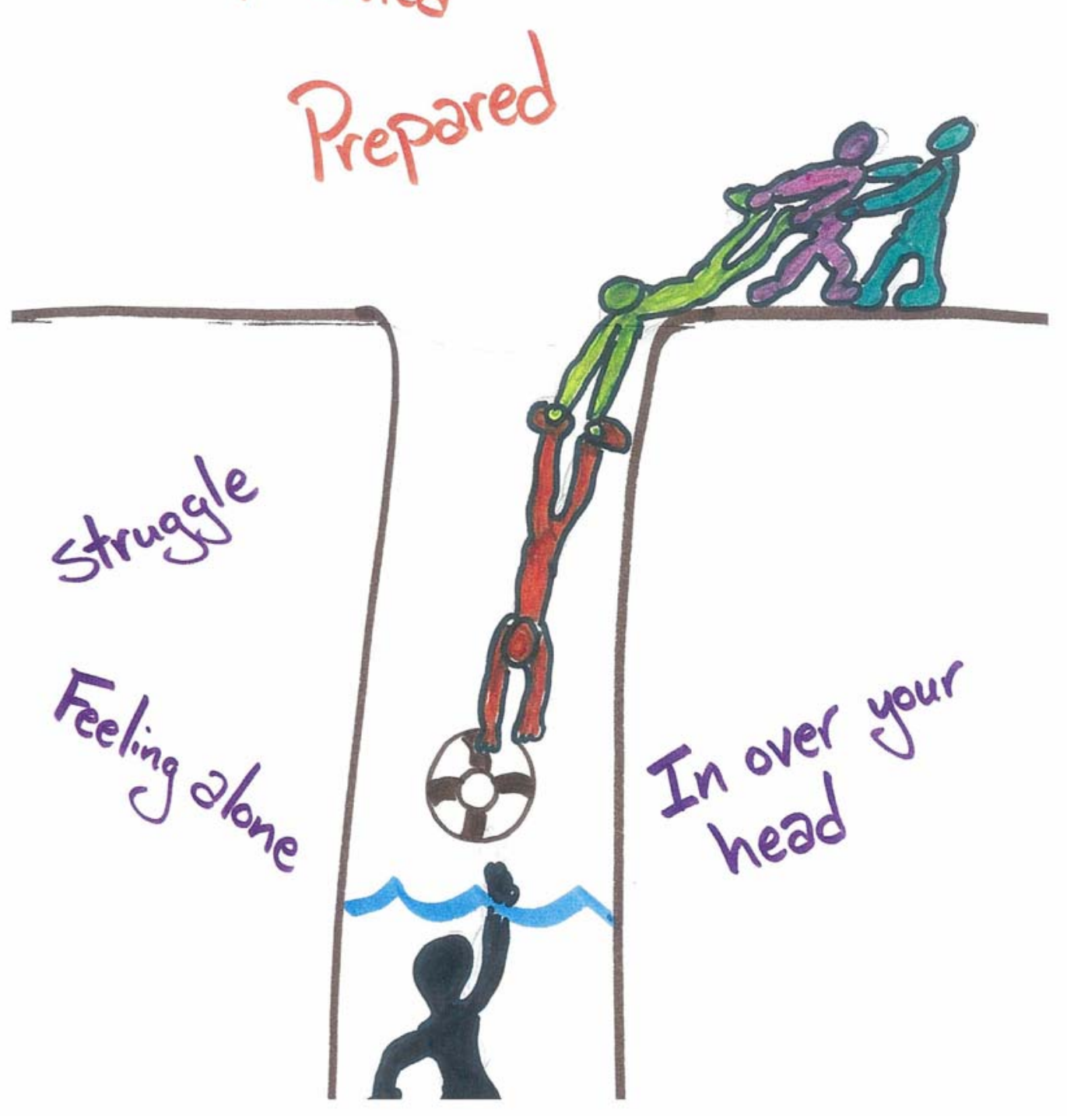

209 

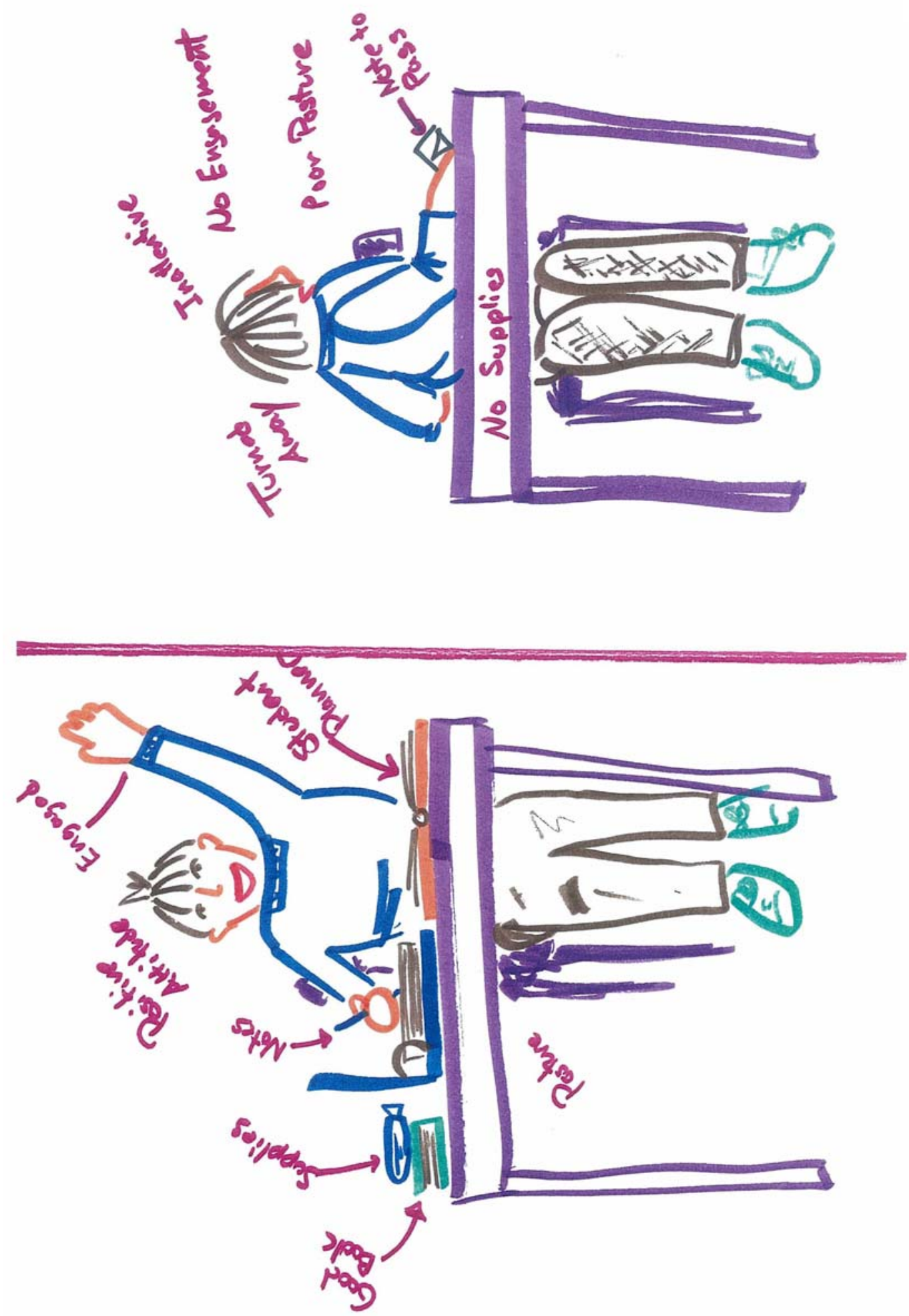
(20)
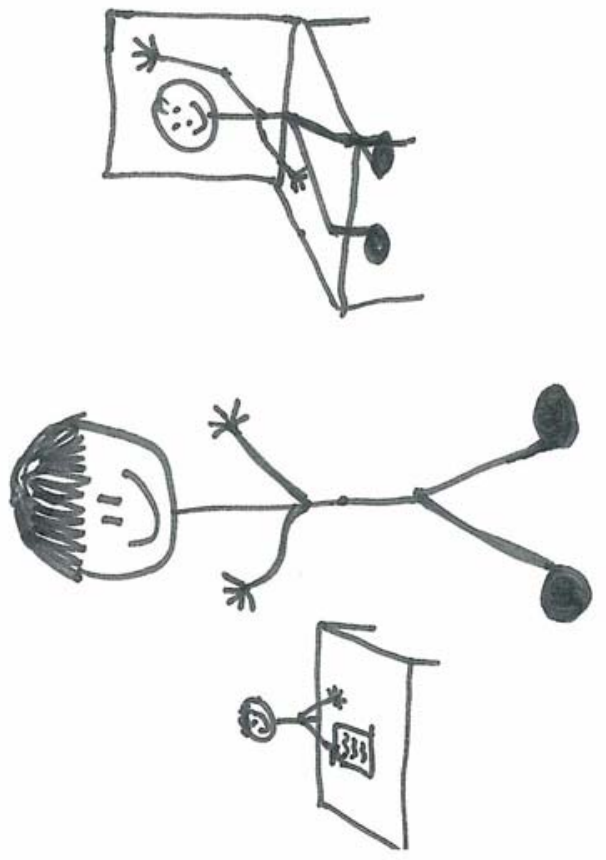


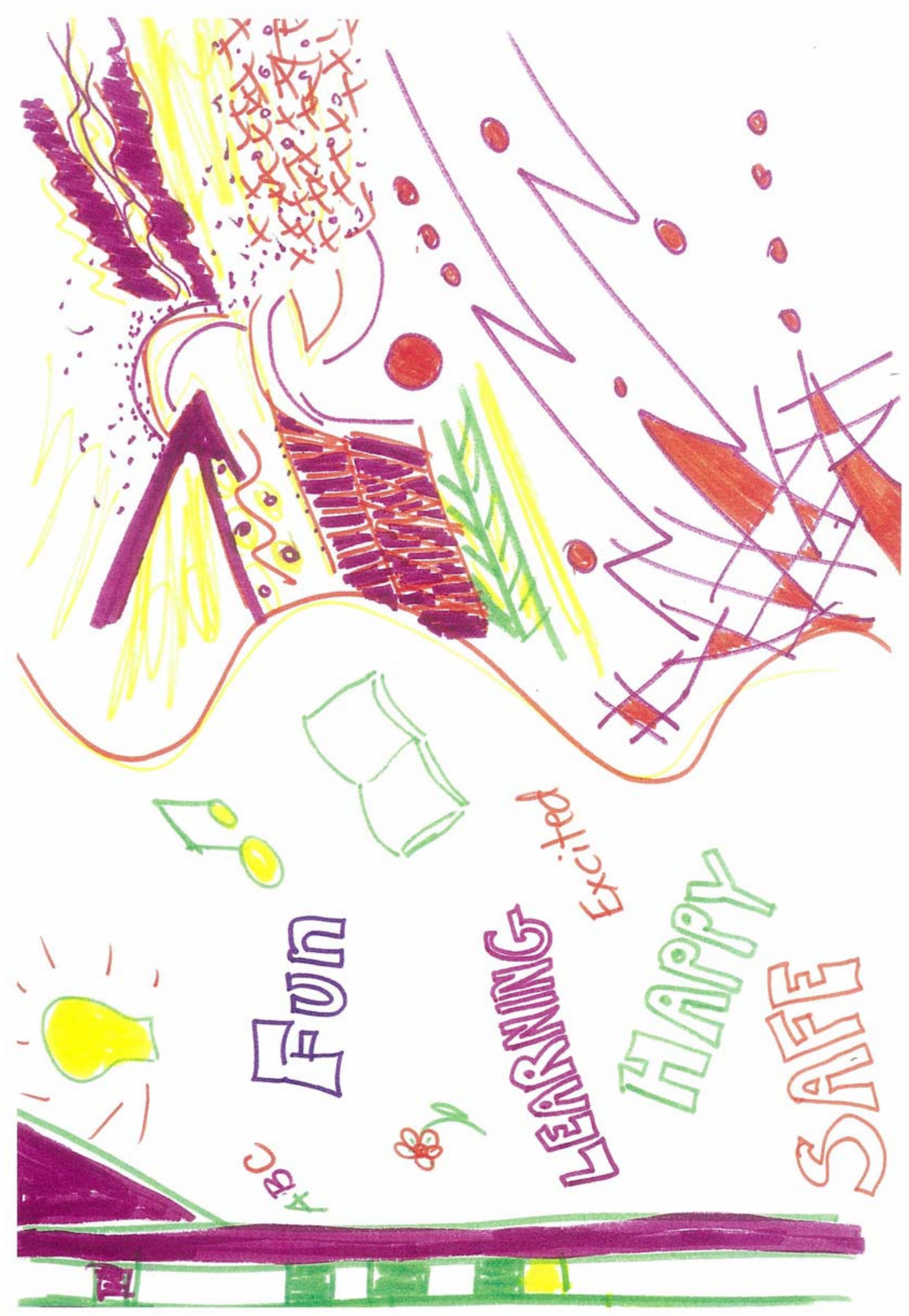



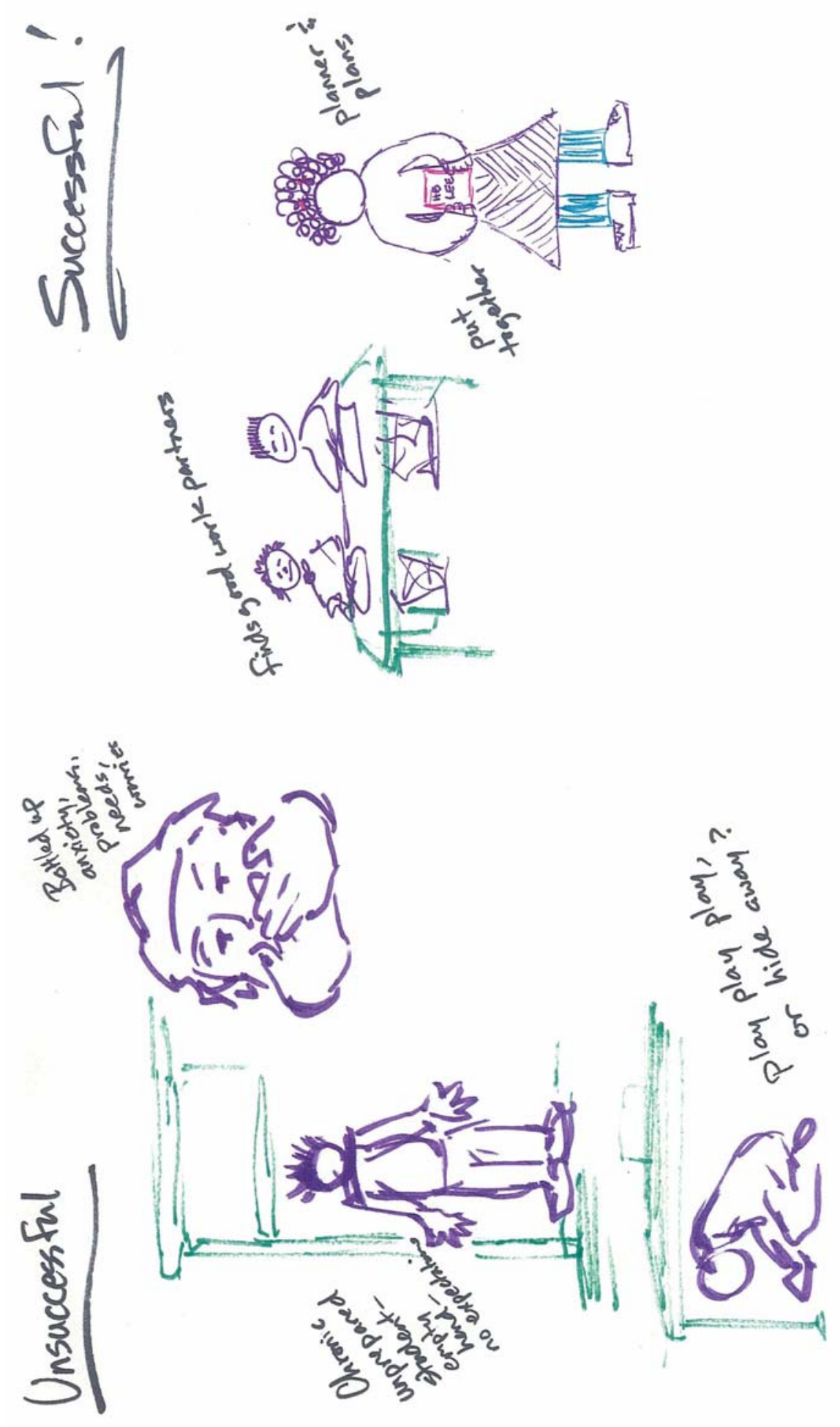

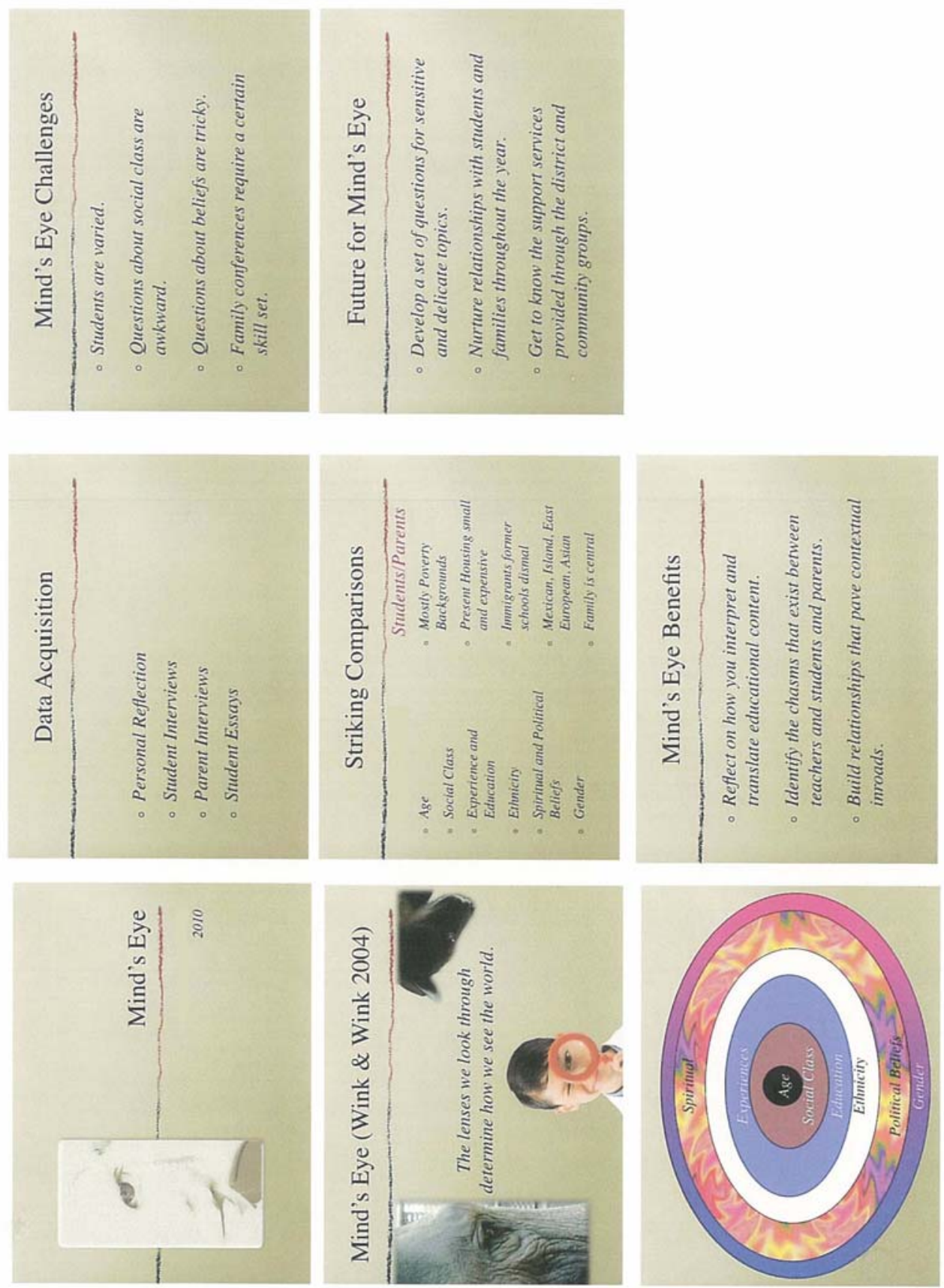

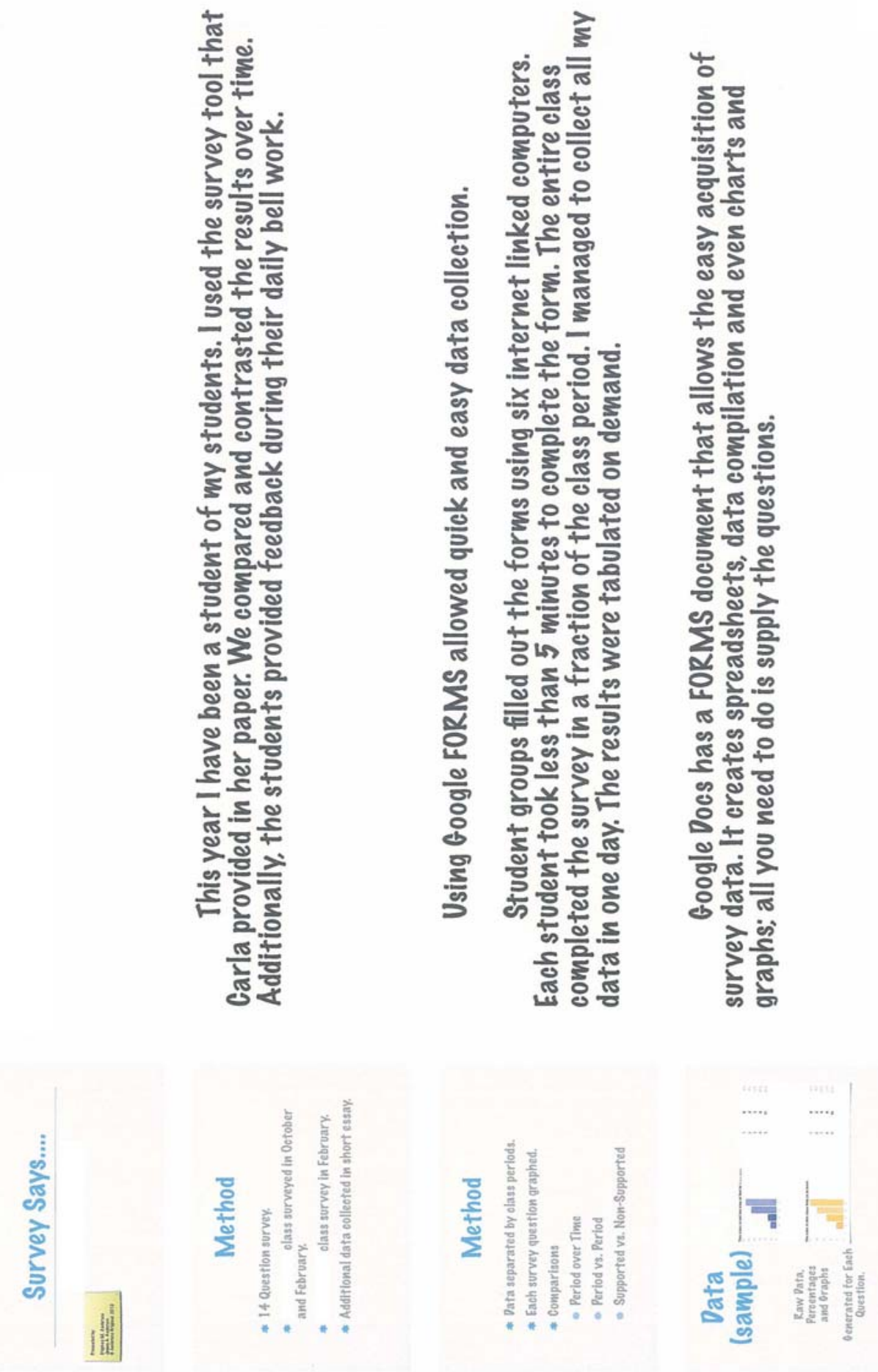

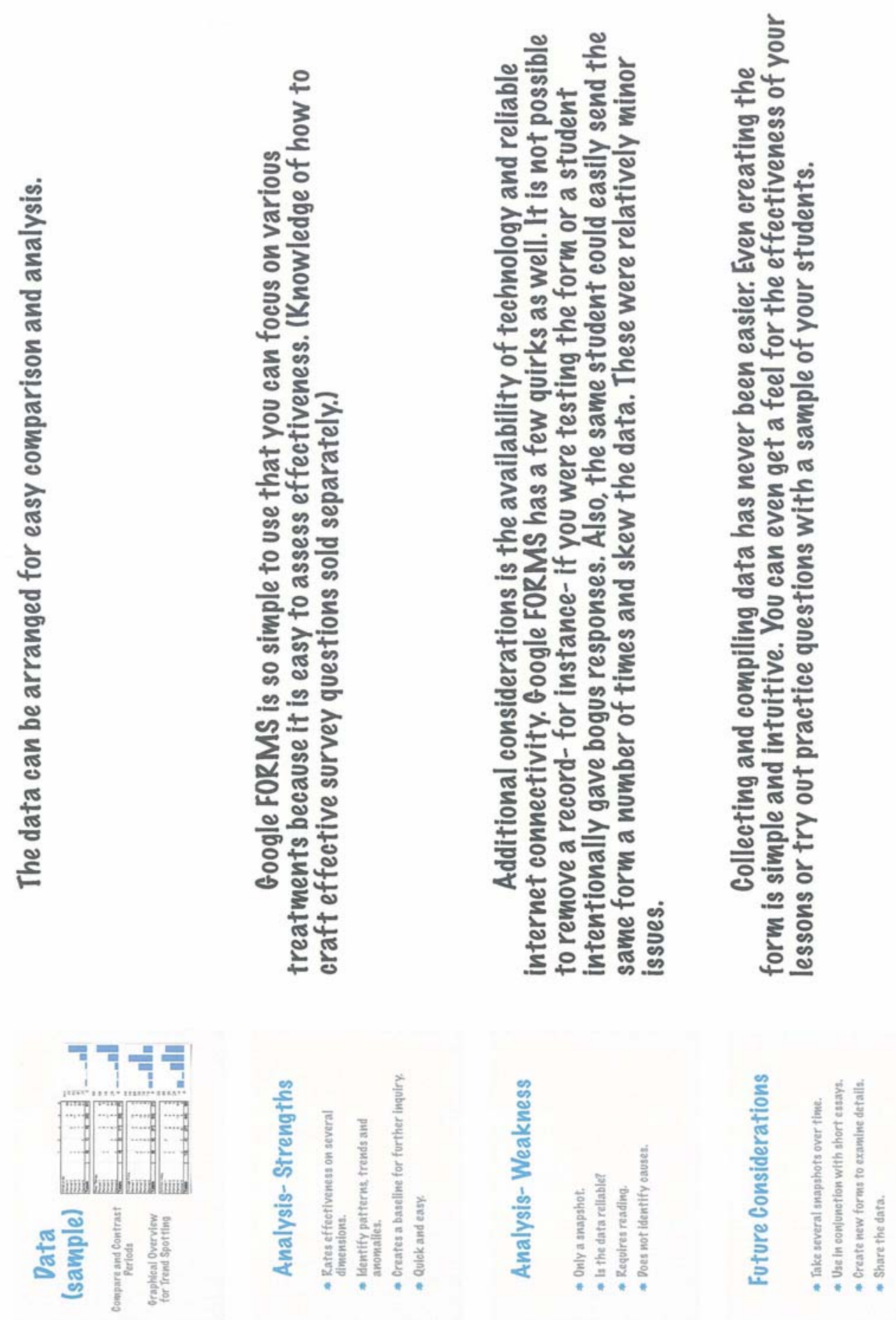
I know what I am supposed to do in class.

20

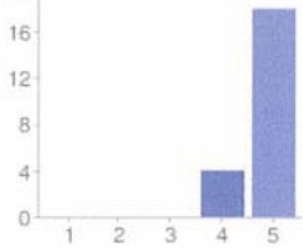

Teacher shows us how to do new things.

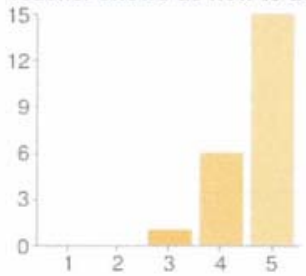

There is enough time to finish class work.

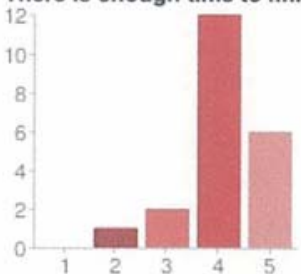

This class is not too noisy or rowdy for learning.

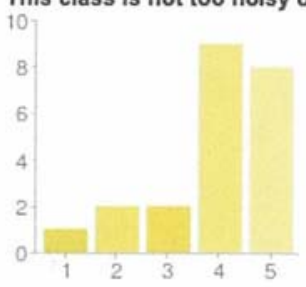

$0 \%$

$0 \%$

$0 \%$

$18 \%$

$82 \%$

$\begin{array}{rrr}1 & 0 & 0 \% \\ 2 & 0 & 0 \% \\ 3 & 1 & 5 \% \\ 4 & \mathbf{6} & 27 \% \\ 5 & \mathbf{1 5} & 68 \%\end{array}$

$\begin{array}{rrr}1 & \mathbf{0} & 0 \% \\ 2 & \mathbf{1} & 5 \% \\ 3 & \mathbf{2} & 10 \% \\ 4 & \mathbf{1 2} & 57 \% \\ 5 & \mathbf{6} & 29 \%\end{array}$


TAW921R v 4.0 .02

Page:

\section{Report Cycle Marks And Comments}

31-JAN-2010 02:12 am

Teacher Name

$B$ This is a B +.

A

F Mark, improvement comes with practice. Attempt more work. Ask for the help you need. Complete assignments outside of class.

B Andrew, your attitude has really helped salvage a low progress report. Keep up the hard work and the positive attitude. You win the most improved award.

D Vanessa, improvement comes with practice. Attempt more work. Ask for the help you need. Complete assignments outside of class.

F Jacob, I noticed that things seem harder for you right now. Let's work together to change things for the better.

F Jonathan, your motivation needs to begin inside of you. Your contributions to discussions is great. I do not understand why you don't produce more schoolwork.

Help me.

F Valeria, your grade went down since the progress report time. We need to build a new strategy for your success. I know people who can help.

8 Gladys, this is a B+

F Detrick, your friends are leaving you behind academically. I understand that you are capable of catching up. Show your mother that you can do better before it is too late. The longer you wait, the harder it will be to succeed.

C This is a minus grade.

D Tyler, your grades have slipped. It's time to do something about it.

B Laura, you have demonstrated incredible progress. Your hard work is paying off. Keep up the pace.

D Rachelle, your grade has slipped since progress report. I will check your assignments before you turn them in so you have time to work on improving your scores.

B Zach, work on your penmanship. It will help you communicate more clearly.

F Amanda, show me the principles of AVID and I will show you improved grades and a

F Ofelio, there are many doors that are open. Walk through them before they close. The longer you wait, the harder your life will become. The change begins from inside of $B^{\text {you. }}$

C Theo, you have improved a great deal since your progress report. Work hard.

$\mathrm{B}$ This is a $\mathrm{B}+$.

F Erika, your grade has dropped since your progress report. School requires hard work, A determination and perseverance.

A

D Yoana, your grade has dropped since your progress report. School requires hard work, determination and perseverance. 

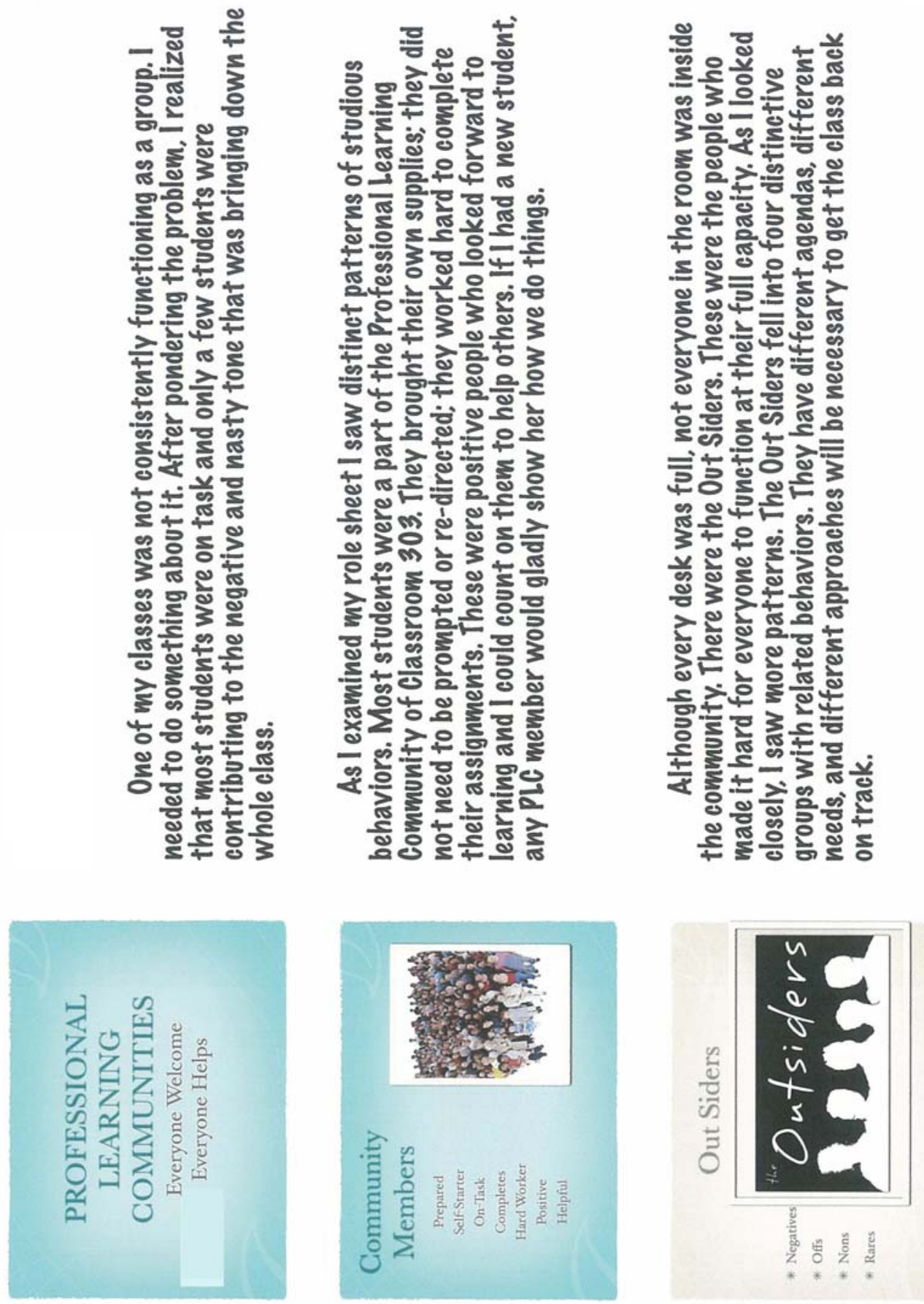

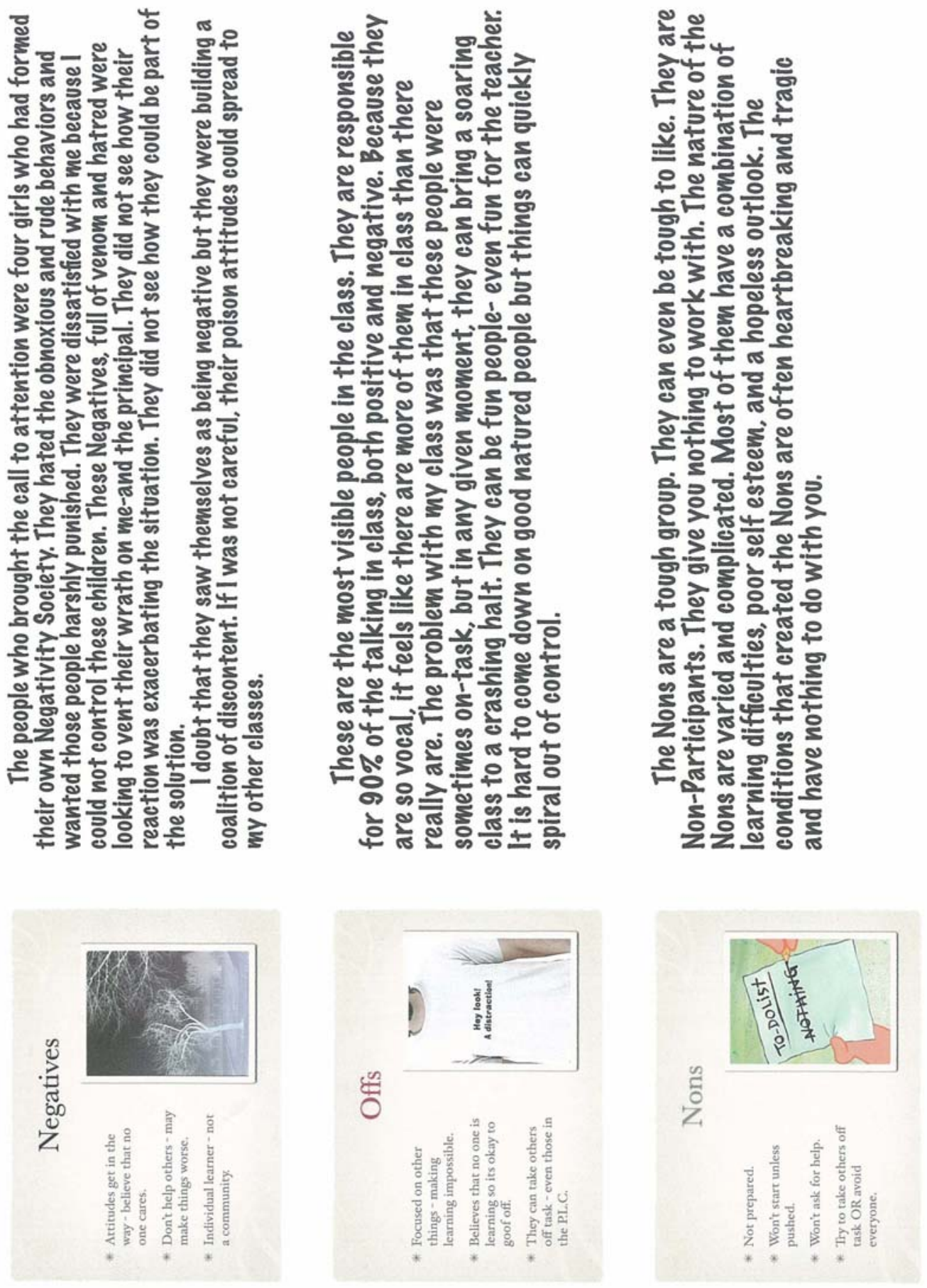

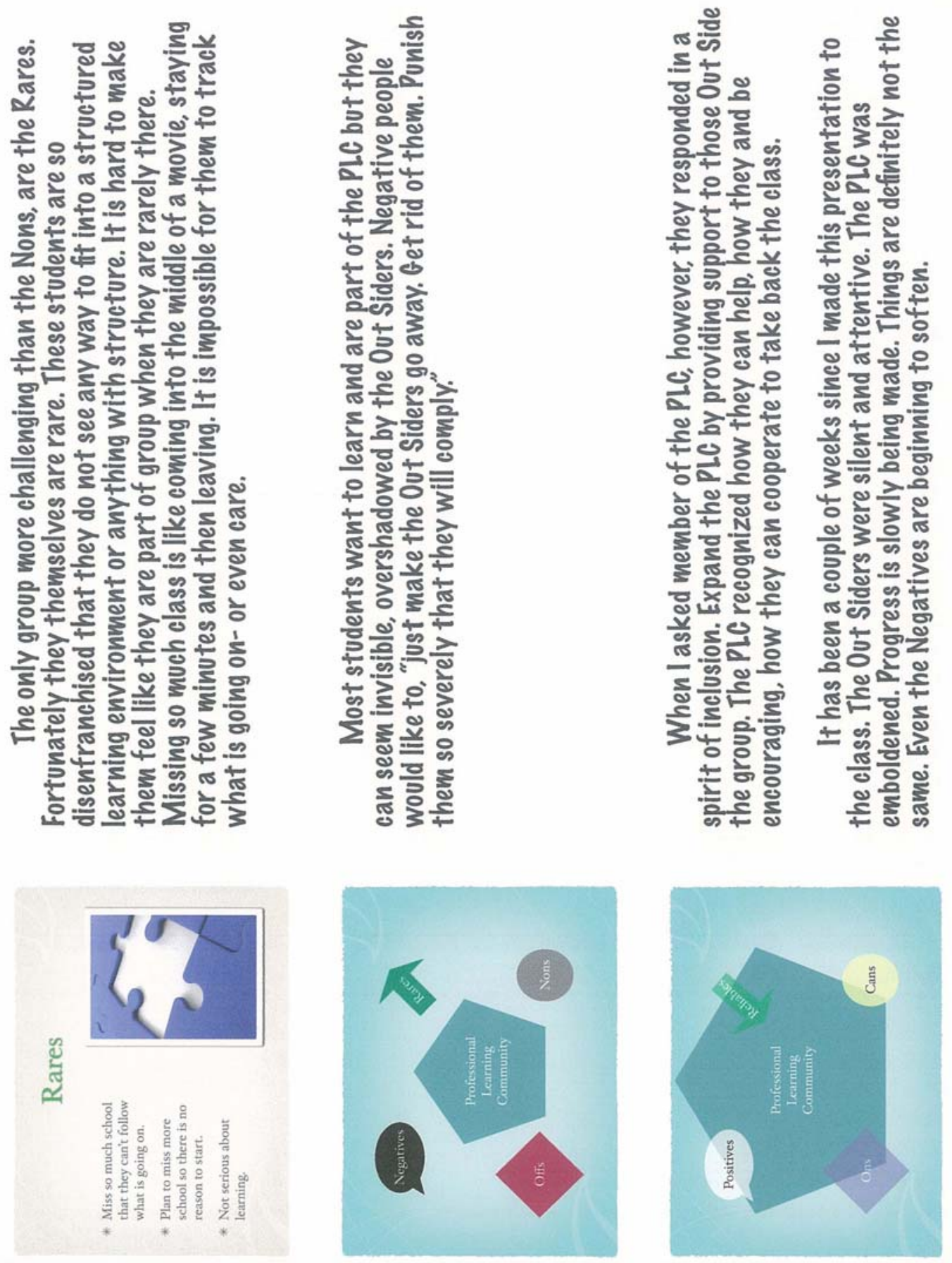


\section{PROFESSIONAL GOAL SETTING AND ACTIVITY FORM}

EDUCATOR:

Date: March 12, 2010

Subject/Grade: Middle school math teacher

\begin{tabular}{l} 
Goal/Objective: \\
Specific, realistic, manageable and \\
measurable objective stating what you hope \\
to achieve. \\
\hline I will collaborate with \\
on "Literacy in the Mathematics \\
Classroom". We will meet twice a \\
month to discuss the books. During the \\
course of the year, we will collaborate \\
on at least one mathematics unit that \\
uses literacy strategies from the texts.
\end{tabular}

Action Plan: Strategies, activities, or methods you believe will use to accomplish your goal.) What support or resources will you need to accomplish your goal?

Our plan is to do two Book Studies:

- "Literacy Strategies for Improving Mathematics Instruction" by Joan M. Kenney

- "Math Wonders to Inspire Teachers and Students" by Alfred S. Posamentier

Using the ideas and activities from the books, we will intertwine math and literacy strategies to improve students' access to the content.

Specific Performance Indicators: Activity Progress:

This section describes how you will measure your success and progress.

- Notes from meetings (highlighting "aha" moments)

- Pre and post-tests

- Unit plan works" to turn into a resource toolkit for other teachers 